\title{
Enhanced Component Performance Study: Motor-Driven Pumps 1998-2012
}

\author{
T. E. Wierman
}

October 2013

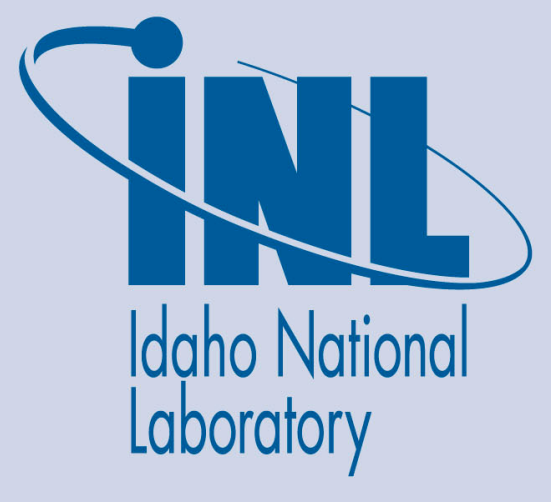

The INL is a U.S. Department of Energy National Laboratory operated by Battelle Energy Alliance 
INL/EXT-14-31122

\title{
Enhanced Component Performance Study: Motor-Driven Pumps 1998-2012
}

\author{
T. E. Wierman
}

October 2013

Update Completed September 2013

\section{Idaho National Laboratory \\ Risk Assessment and Management Services Department Idaho Falls, Idaho 83415}

http://www.inl.gov

Prepared for the Division of Risk Assessment

Office of Nuclear Regulatory Research

U.S. Nuclear Regulatory Commission

Washington, D.C. 20555

Job Code N6631 
NOTICE

This information was prepared as an account of work sponsored by an agency of the U.S. Government. Neither the U.S. Government nor any agency thereof, nor any of their employees, makes any warranty, express or implied, or assumes any legal liability or responsibility for any third party's use, or the results of such use, of any information, apparatus, product, or process disclosed herein, or represents that its use by such third party would not infringe privately owned rights. The views expressed herein are not necessarily those of the U.S. Nuclear Regulatory Commission. 



\begin{abstract}
This report presents an enhanced performance evaluation of motor-driven valves (MDPs) at U.S. commercial nuclear power plants. The data used in this study are based on the operating experience failure reports from fiscal year 1998 through 2012 for the component reliability as reported in the Equipment Performance and Information Exchange (EPIX). The MDP failure modes considered for standby systems are failure to start, failure to run less than or equal to 1 hour, and failure to run more than 1 hour; for normally running systems, the failure modes considered are failure to start and failure to run. An 8-hr unreliability estimate is also calculated and trended. The component reliability estimates and the reliability data are trended for the most recent 10 year period while yearly estimates for reliability are provided for the entire active period. One statistically significant increasing trend was identified in the MDP results for standby MDP run hours per reactor critical year. Statistically significant decreasing trends were identified for unreliability (for standby and normally running systems) frequency of failure-to-start events for standby systems and failure probability for standby systems.
\end{abstract}




\section{CONTENTS}

ABSTRACT iii

ACRONYMS ix

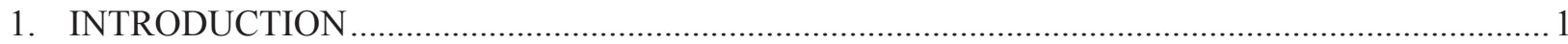

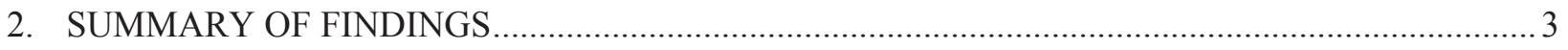

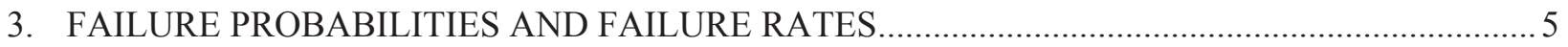

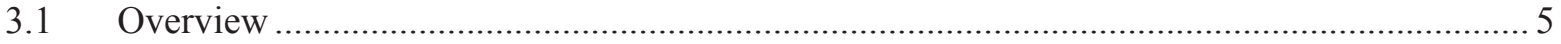

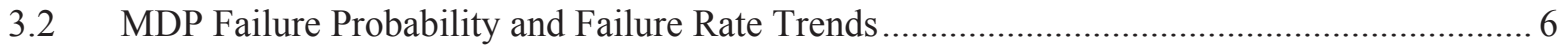

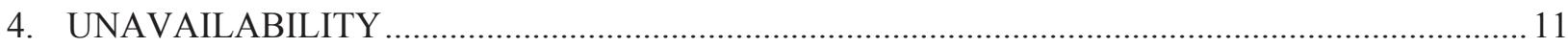

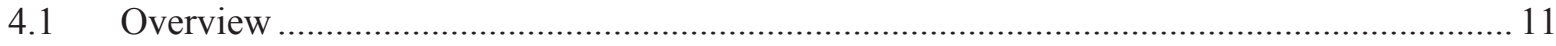

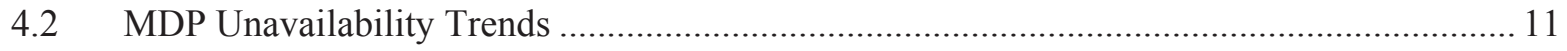

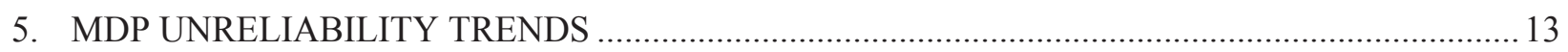

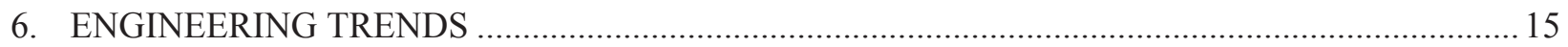

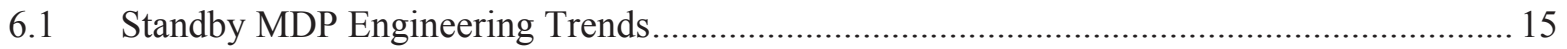

$6.2 \quad$ Normally Running MDP Engineering Trends................................................................ 18

6.3 Comparison of EPIX MDP Unplanned Demand Results with Industry Results for Standby

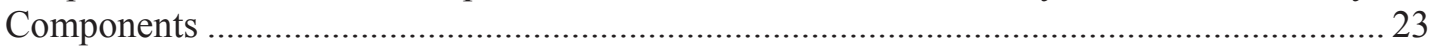

6.4 MDP Engineering Analysis by Failure Modes.................................................................... 23

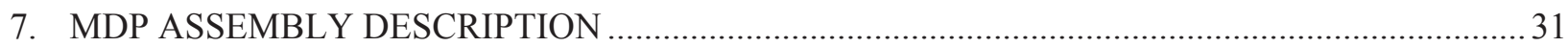

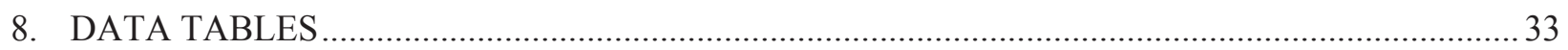

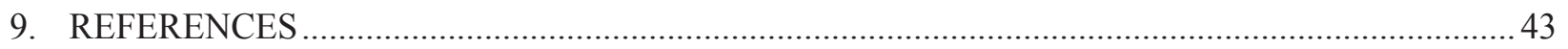

FIGURES

1. Failure probability estimate trend for standby systems, industry-wide MDP FTS trend....................... 6

2. Failure probability estimate trend for standby systems, industry-wide MDP FTR $\leq 1 \mathrm{H}$ trend. .............. 7

3. Failure rate estimate trend for standby systems, industry-wide MDP FTR $>1 \mathrm{H}$ trend........................ 7

4. Failure probability estimate trend for normally running systems, industry-wide MDP FTS trend. 
5. Failure rate estimate trend for normally running systems, industry-wide MDP FTR trend.

6. Pooled AFW, HPI, and HCS MDP UA trend.

7. Standby systems, industry-wide MDP unreliability trend (8-hour mission).

8. Normally running systems (MFW), industry-wide MDP unreliability trend (8-hour mission).

9. Frequency (demands per reactor year) of start demands, standby MDPs.

10. Standby MDP run hours per reactor critical year of run $\leq 1 \mathrm{H}$ hours.

11. Standby MDP run hours per reactor critical year. 16

12. Frequency (failures per reactor year) of FTS events, standby MDPs. 17

13. Frequency (failures per reactor year) of FTR $\leq 1 \mathrm{H}$ events, standby MDPs. 17

14. Frequency (failures per reactor year) of FTR $>1 \mathrm{H}$ events, standby MDPs. 18

15. Frequency (demands per reactor year) of start demands, normally running MDPs. 19

16. Normally running MDP run hours per reactor critical year. 19

17. Frequency (failures per reactor year) of FTS events, normally running MDPs. 20

18. Frequency (failures per reactor year) of FTR events, normally running MDPs. 20

19. MDP failure breakdown by period, sub component, and failure mode. .26

20. MDP breakdown by time period, cause group, and failure mode.

21. MDP component failure distribution by period, failure mode, and method of detection. 28

22. MDP component failure distribution by period, failure mode, and recovery. 29

\section{TABLES}

1. MDP systems. 5

2. Industry-wide distributions of $\mathrm{p}$ (failure probability) and $\lambda$ (hourly rate) for MDPs............................ 5

3. Industry-wide distributions of unavailability for MDPs. 11

4. Summary of standby MDP failure counts for the FTS failure mode over time by system. 21

5. Summary of standby MDP failure counts for the FTR $\leq 1 \mathrm{H}$ failure mode over time by system. 21

6. Summary of standby MDP failure counts for the FTR $>1 \mathrm{H}$ failure mode over time by system. 21 
7. Summary of normally running MDP failure counts for the FTS failure mode over time by system.

8. Summary of normally running MDP failure counts for the FTR failure mode over time by system.

9. Standby MDP unplanned demand performance comparison with industry-average performance.

10. Component failure cause groups.

11. Plot data for standby MDP FTS industry trend. Figure 1 33

12. Plot data for standby MDP FTR $\leq 1 \mathrm{H}$ industry trend. Figure 2 . 33

13. Plot data for standby MDP FTR $>1 \mathrm{H}$ industry trend. Figure 3. 34

14. Plot data for normally running MDP FTS industry trend. Figure 4. 34

15. Plot data for normally running MDP FTR industry trend. Figure 5 .35

16. Plot data for all standby MDP unavailability trend. Figure 6 .35

17. Plot data for Standby MDP unreliability trend. Figure 7 .36

18. Plot data for NR MDP unreliability trend. Figure 8 . .36

19. Plot data for standby MDP start demands trend. Figure 9 37

20. Plot data for standby MDP run $\leq 1$-hour run-hours trend. Figure 10 37

21. Plot data for standby MDP run-hours trend. Figure 11 38

22. Plot data for standby MDP FTS events trend. Figure 12 ....... .38

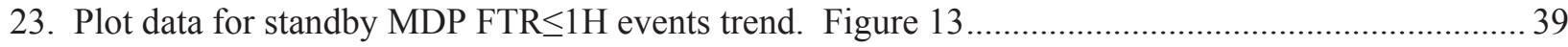

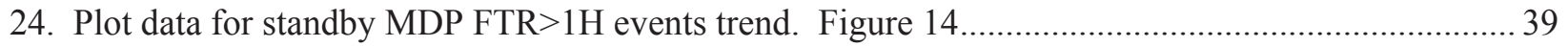

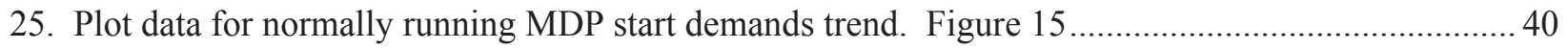

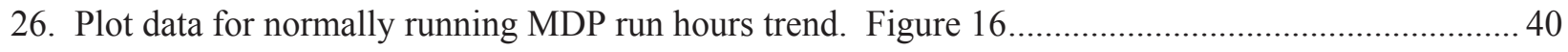

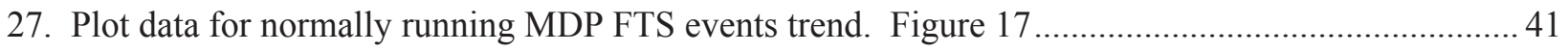

28. Plot data for normally running MDP FTR events trend. Figure 18 41 


\section{ACRONYMS}

\begin{tabular}{|c|c|}
\hline AFW & auxiliary feedwater \\
\hline BWR & boiling water reactor \\
\hline $\mathrm{CCW}$ & closed cooling water \\
\hline CNID & constrained noninformative prior distribution \\
\hline $\begin{array}{l}\text { EPIX } \\
\text { ESF } \\
\text { ESW }\end{array}$ & $\begin{array}{l}\text { Equipment Performance and Information Exchange } \\
\text { engineered safety feature } \\
\text { essential service water }\end{array}$ \\
\hline $\begin{array}{l}\text { FTR } \leq 1 \mathrm{H} \\
\text { FTR }>1 \mathrm{H} \\
\text { FTR } \\
\text { FTS } \\
\text { FY }\end{array}$ & $\begin{array}{l}\text { failure to run } \leq 1 \text { hour } \\
\text { failure to run }>1 \text { hour } \\
\text { failure to run } \\
\text { failure to start } \\
\text { fiscal year }\end{array}$ \\
\hline $\begin{array}{l}\text { HPCS } \\
\text { HPSI }\end{array}$ & $\begin{array}{l}\text { high-pressure core spray } \\
\text { high -pressure safety injection }\end{array}$ \\
\hline $\begin{array}{l}\text { MDP } \\
\text { MSPI }\end{array}$ & $\begin{array}{l}\text { motor-driven pump } \\
\text { Mitigating Systems Performance Index }\end{array}$ \\
\hline $\begin{array}{l}\text { PRA } \\
\text { PWR }\end{array}$ & $\begin{array}{l}\text { probabilistic risk assessment } \\
\text { pressurized water reactor }\end{array}$ \\
\hline RHR & residual heat removal \\
\hline UA & unavailability \\
\hline
\end{tabular}




\section{Enhanced Component Performance Study: Motor-Driven Pumps 1998-2012}

\section{INTRODUCTION}

This report presents an enhanced performance evaluation of motor-driven pumps (MDPs) at U.S. commercial nuclear power plants. This report does not estimate values for use in probabilistic risk assessments (PRAs), but does evaluate component performance over time. The 2010 Component Reliability Update (Reference 1), which is an update to Reference 2 (NUREG/CR-6928), reports the MDP unreliability estimates using Equipment Performance and Information Exchange (EPIX) data from 1998 through 2010 and maintenance unavailability (UA) performance data using Mitigating Systems Performance Index (MSPI) Basis Document data from 2002 through 2010.

The data used in this study are based on the operating experience failure reports from fiscal year (FY)-98 through FY-12 as reported in EPIX. The MDP failure modes considered are for standby systems: failure to start (FTS), failure to run $\leq 1$ hour $(\mathrm{FTR} \leq 1 \mathrm{H})$, failure to run $>1$ hour $(\mathrm{FTR}>1 \mathrm{H})$, and for normally running systems: FTS and failure-to-run (FTR). MDP train maintenance unavailability data for trending are from the same time period, as reported in the Reactor Oversight Program and EPIX. In addition to the presentation of the component failure mode data and the UA data, an 8-hr unreliability is calculated and trended. The component reliability estimates and the reliability data are trended for the most recent 10-yr period while yearly estimates for reliability are provided for the entire active period.

Previously, the study relied on operating experience obtained from licensee event reports, Nuclear Plant Reliability Data System, and EPIX. The EPIX database (which includes as a subset the MSPI designated devices) has matured to the point where component availability and reliability can be estimated with a higher degree of assurance of accuracy. In addition, the population of data is much larger than the population used in the previous study.

The objective of the effort for the updated component performance studies is to obtain annual performance trends of failure rates and probabilities. An overview of the trending methods, glossary of terms, and abbreviations can be found in the Overview and Reference document on the Reactor Operational Experience Results and Databases web page.

The objective of the enhanced component performance study is to present an analysis of factors that could influence the system and component trends in addition to annual performance trends of failure rates and probabilities. The factors analyzed for the MDP component are the differences in failures between total demands and actual unplanned [engineered safety feature (ESF)] demands (Section 6.3). Statistical analyses of the differences are performed and results showing whether pooling is acceptable across these factors are shown. In addition, engineering analyses were performed with respect to time period and failure mode (Section 6.4). The factors analyzed are: sub-component, failure cause, recovery, and detection method 


\section{SUMMARY OF FINDINGS}

The results of this study are summarized in this section. Of particular interest is the existence of any statistically significanta increasing trends. In this update, the following statistically significant increasing trend was identified in the MDP results:

- Standby MDP run hours per reactor critical year (see Figure 11)

This trend is not an adverse trend; it only indicates an increase in run hours for standby pumps. Standby MDP run hours appear to have made a step change in the upward direction in FY 2002 and FY 2003, which coincides with the start of the MSPI program. This influences an increasing trend over the 2003 to 2012 period.

Statistically significant decreasing trends were identified in the MDP results for the following:

- Standby systems, industry-wide MDP unreliability trend (8-hour mission) (see Figure 7)

- Normally running systems (MFW), industry-wide MDP unreliability trend (8-hour mission) (see Figure 8).

Highly statistically significant decreasing trends in the MDP results were identified for the following:

- Frequency (failures per reactor year) of FTS events, standby MDPs (see Figure 12)

- Failure probability estimate trend for standby systems, industry-wide MDP FTS trend (see Figure 1).

An ongoing concern in the industry is whether industry data adequately represent standby component performance during unplanned (ESF) demands. Section 6.3 shows the results of the consistency check between industry data and ESF detected failure data. The FTS, FTR $<1 \mathrm{H}$, and FTR $>1 \mathrm{H}$ failure mode distributions as well as the total unreliability (8 hours) detected under ESF are superior (smaller) than the industry average distribution.

a. Statistically significant is defined in terms of the 'p-value.' A p-value is a probability indicating whether to accept or reject the null hypothesis that there is no trend in the data. P-values of less than or equal to 0.05 indicate that we are $95 \%$ confident that there is a trend in the data (reject the null hypothesis of no trend.) By convention, we use the "Michelin Guide" scale: p-value $<0.05$ (statistically significant), p-value $<0.01$ (highly statistically significant); pvalue $<0.001$ (extremely statistically significant). 


\section{FAILURE PROBABILITIES AND FAILURE RATES}

\subsection{Overview}

The industry-wide failure probabilities and failure rates of MDPs have been calculated from the operating experience for FTS, FTR $\leq 1 \mathrm{H}, \mathrm{FTR}>1 \mathrm{H}$, and FTR. The MDP data set obtained from EPIX includes MDPs in the systems listed in Table 1. MDPs are categorized as either standby or normally running. This report follows the definition of these categories in Reference 1, which determines the status by evaluating the number of run-hours per demand. Those pumps with low run-hours per demand are standby $(\leq 360)$ and those that are high are normally running $(>360)$. Table 2 shows industry-wide failure probability and failure rate results for the MDP from Reference 1.

Table 1. MDP systems.

\begin{tabular}{llccc}
\hline System & \multicolumn{1}{c}{ Description } & Total & Standby & $\begin{array}{c}\text { Normally } \\
\text { Running }\end{array}$ \\
\hline AFW & Auxiliary feedwater & 123 & 123 & \\
CCW & Component cooling water & 287 & & 287 \\
CDS & Condensate system & 140 & & 140 \\
CRD & Control rod drive & 47 & 8 & 39 \\
CSR & Containment spray recirculation & 156 & 156 & \\
CVC & Chemical and volume control & 8 & & 8 \\
HCS & High pressure core spray & 9 & 9 & 7 \\
HPI & High pressure injection & 170 & 163 & 5 \\
LCS & Low pressure core spray & 75 & 70 & 43 \\
MFW & Main feedwater & 43 & & \\
RHR & Residual heat removal & 292 & 292 & 96 \\
SWN & Normally running service water & 96 & & 1 \\
SWS & Standby service water & 396 & 395 & 626 \\
\hline
\end{tabular}

The MDPs are assumed to operate both when the reactor is critical and during shutdown periods. The number of MDPs in operation is assumed to be constant throughout the study period. All demand types are considered - testing, non-testing, and, as applicable, ESF demands.

Table 2. Industry-wide distributions of $\mathrm{p}$ (failure probability) and $\lambda$ (hourly rate) for MDPs.

\begin{tabular}{|c|c|c|c|c|c|c|c|c|}
\hline \multirow[b]{2}{*}{ Operation } & \multirow{2}{*}{$\begin{array}{l}\text { Failure } \\
\text { Mode }\end{array}$} & \multirow[b]{2}{*}{$5 \%$} & \multirow[b]{2}{*}{ Median } & \multirow[b]{2}{*}{ Mean } & \multirow[b]{2}{*}{$95 \%$} & \multicolumn{3}{|c|}{ Distribution } \\
\hline & & & & & & Type & $\alpha$ & $\beta$ \\
\hline \multirow[t]{3}{*}{ Standby } & FTS & $1.63 \mathrm{E}-04$ & 7.91E-04 & $9.47 \mathrm{E}-04$ & $2.27 \mathrm{E}-03$ & Beta & 1.95 & $2.054 \mathrm{E}+03$ \\
\hline & $\mathrm{FTR} \leq 1 \mathrm{H}$ & $1.93 \mathrm{E}-05$ & $1.01 \mathrm{E}-04$ & $1.23 \mathrm{E}-04$ & $3.01 \mathrm{E}-04$ & Beta & 1.82 & $1.479 \mathrm{E}+04$ \\
\hline & $\mathrm{FTR}>1 \mathrm{H}$ & $2.64 \mathrm{E}-07$ & $6.44 \mathrm{E}-06$ & $1.04 \mathrm{E}-05$ & $3.41 \mathrm{E}-05$ & Gamma & 0.78 & $7.501 \mathrm{E}+04$ \\
\hline \multirow{2}{*}{$\begin{array}{l}\text { Running/ } \\
\text { Alternating }\end{array}$} & FTS & $4.01 \mathrm{E}-04$ & $1.23 \mathrm{E}-03$ & 1.36E-03 & $2.79 \mathrm{E}-03$ & Beta & 3.28 & $2.406 \mathrm{E}+03$ \\
\hline & FTR & 7.36E-07 & $3.03 \mathrm{E}-06$ & $3.53 \mathrm{E}-06$ & $8.02 \mathrm{E}-06$ & Gamma & 2.29 & $6.496 \mathrm{E}+05$ \\
\hline
\end{tabular}




\subsection{MDP Failure Probability and Failure Rate Trends}

The trends are shown for industry standby and for industry normally running results. Trends in the standby MDP failure probabilities and failure rates are shown in Figure 1 to Figure 3. The data for the trend plots are contained in Table 11 to Table 13. The standby systems from Table 1 are trended together for each failure mode. Trends in the failure probabilities and failure rates for normally operating MDPs are shown in Figure 4 and Figure 5. The data for the trend plots are contained in Table 14 and Table 15.

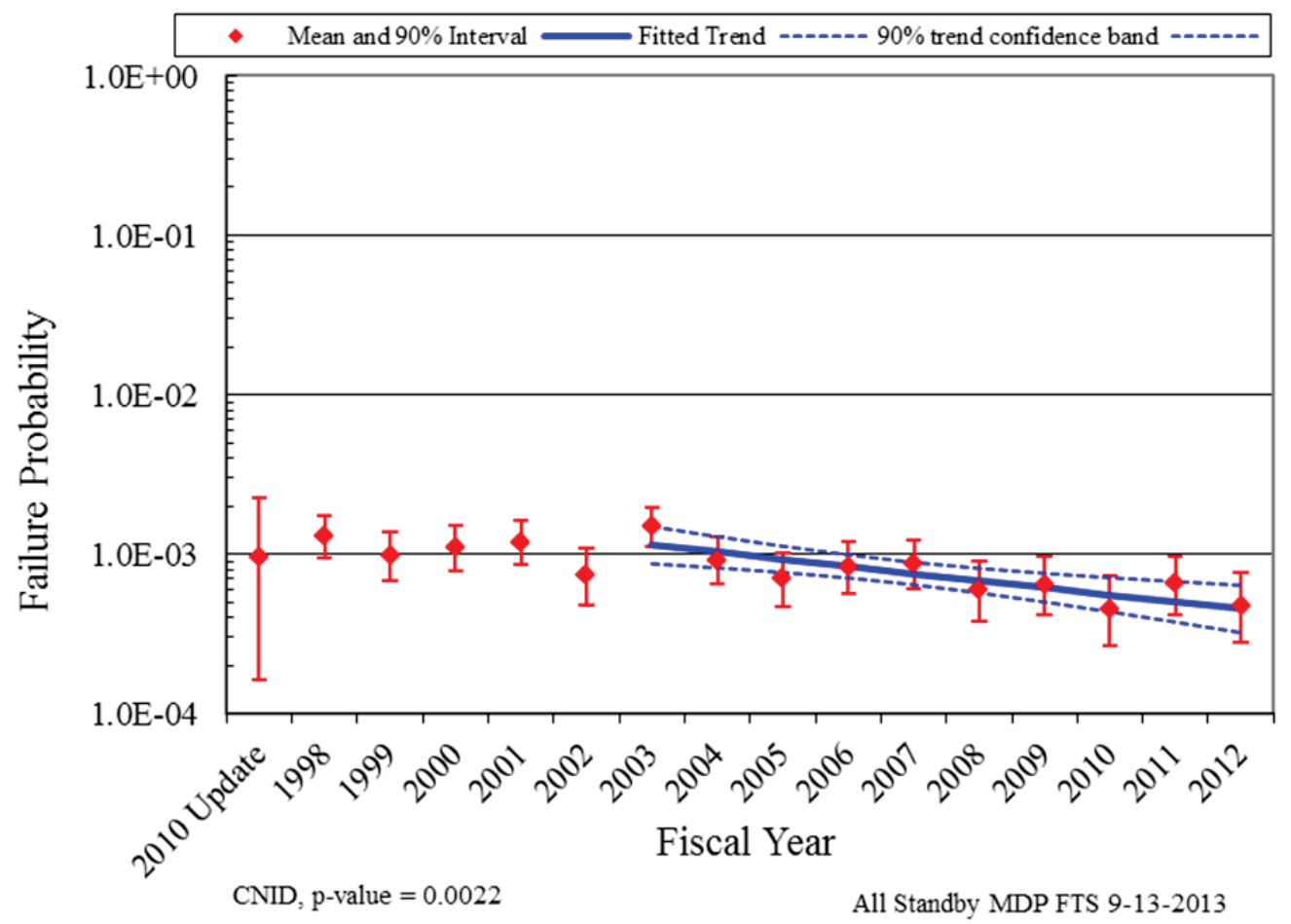

Figure 1. Failure probability estimate trend for standby systems, industry-wide MDP FTS trend. 


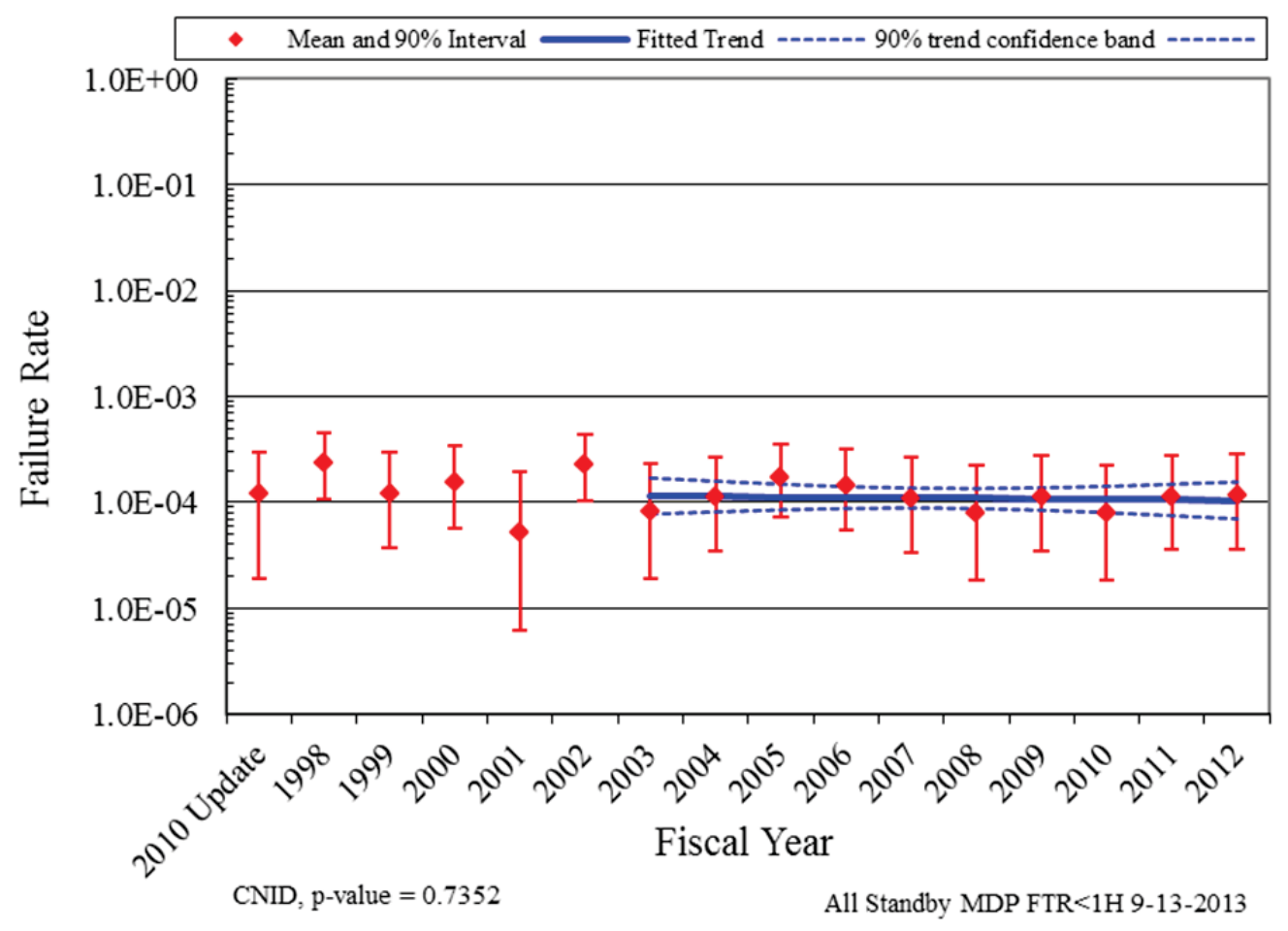

Figure 2. Failure probability estimate trend for standby systems, industry-wide MDP FTR $\leq 1 \mathrm{H}$ trend.

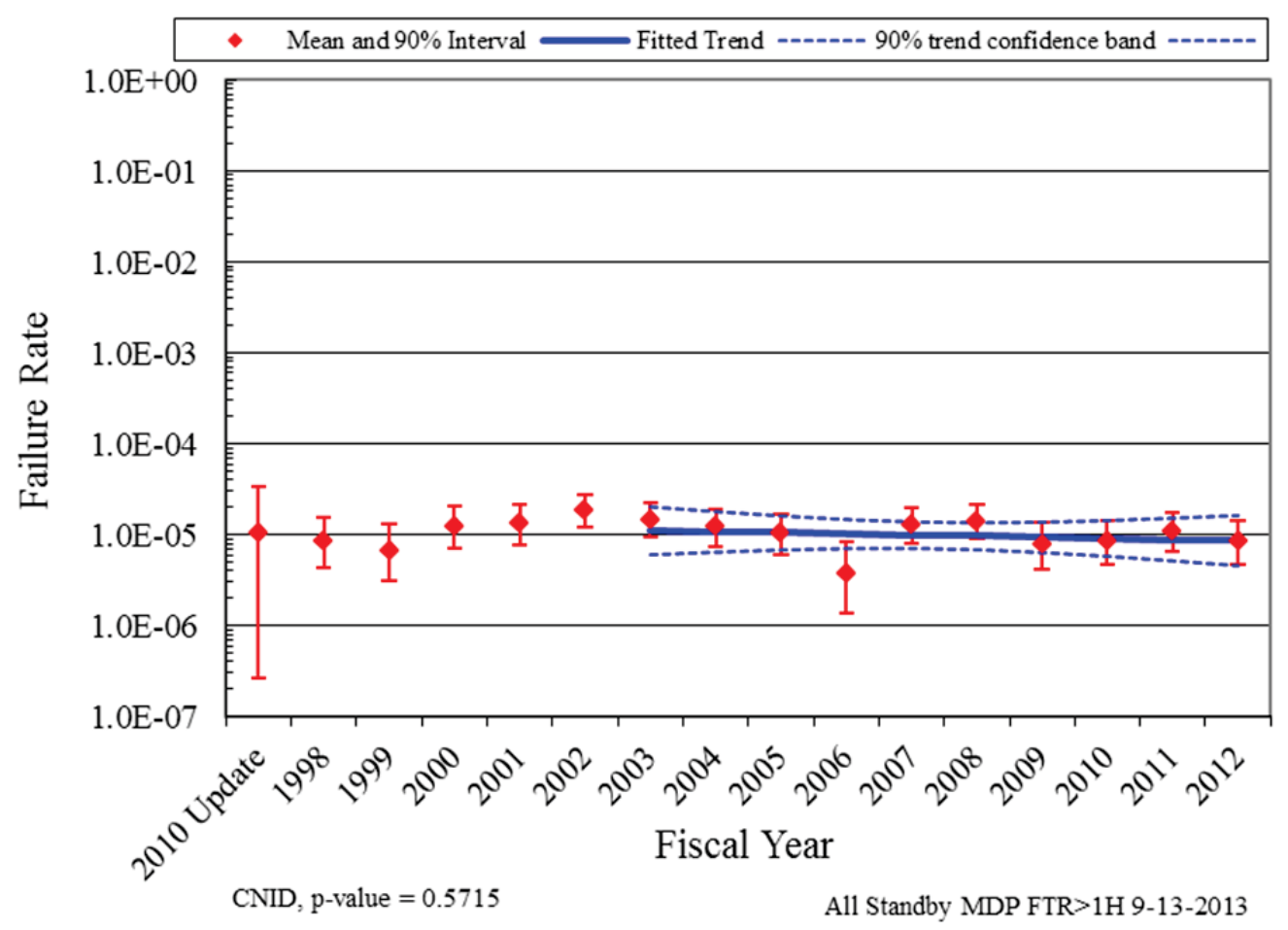

Figure 3. Failure rate estimate trend for standby systems, industry-wide MDP FTR $>1 \mathrm{H}$ trend. 


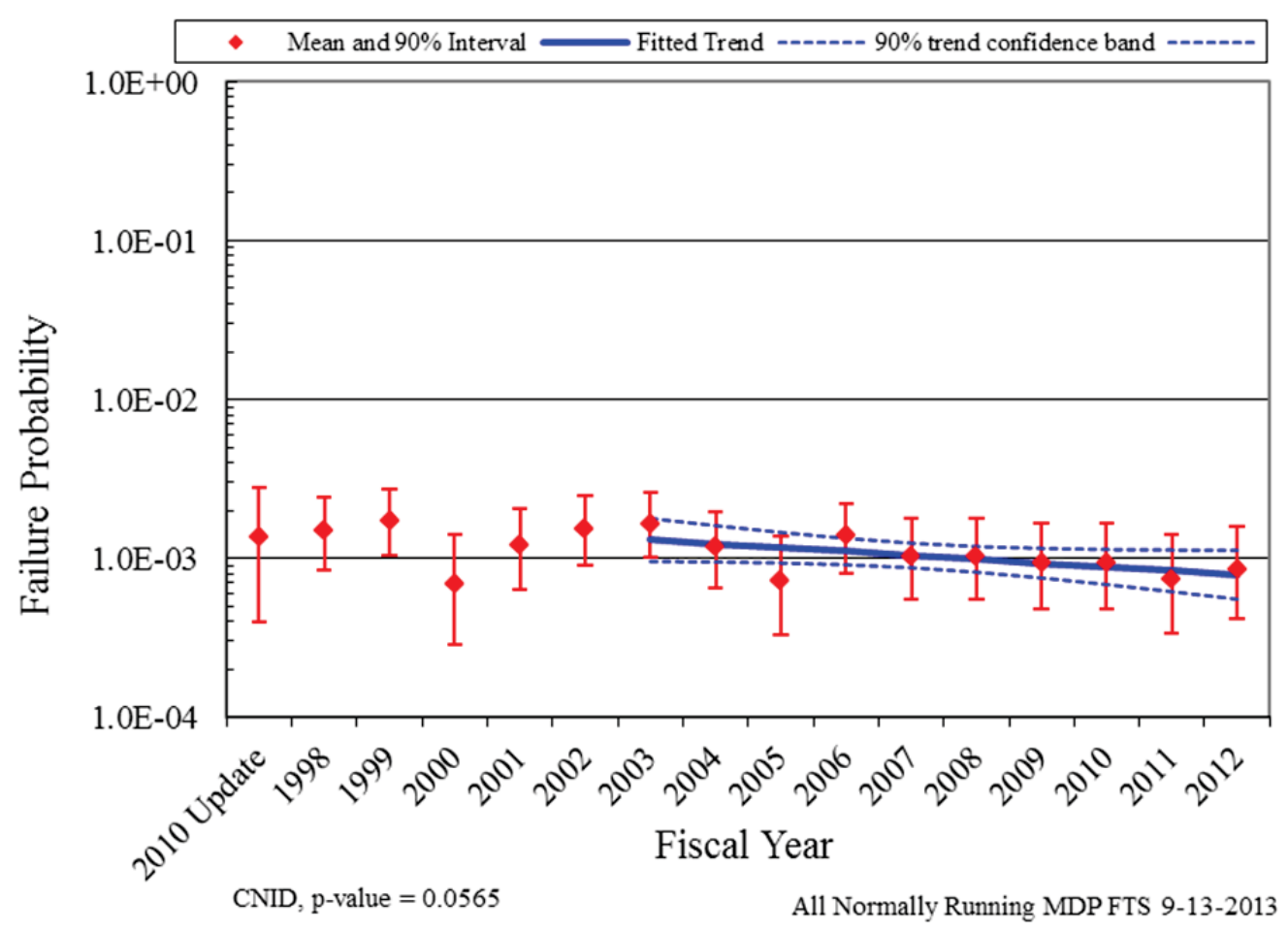

Figure 4. Failure probability estimate trend for normally running systems, industry-wide MDP FTS trend.

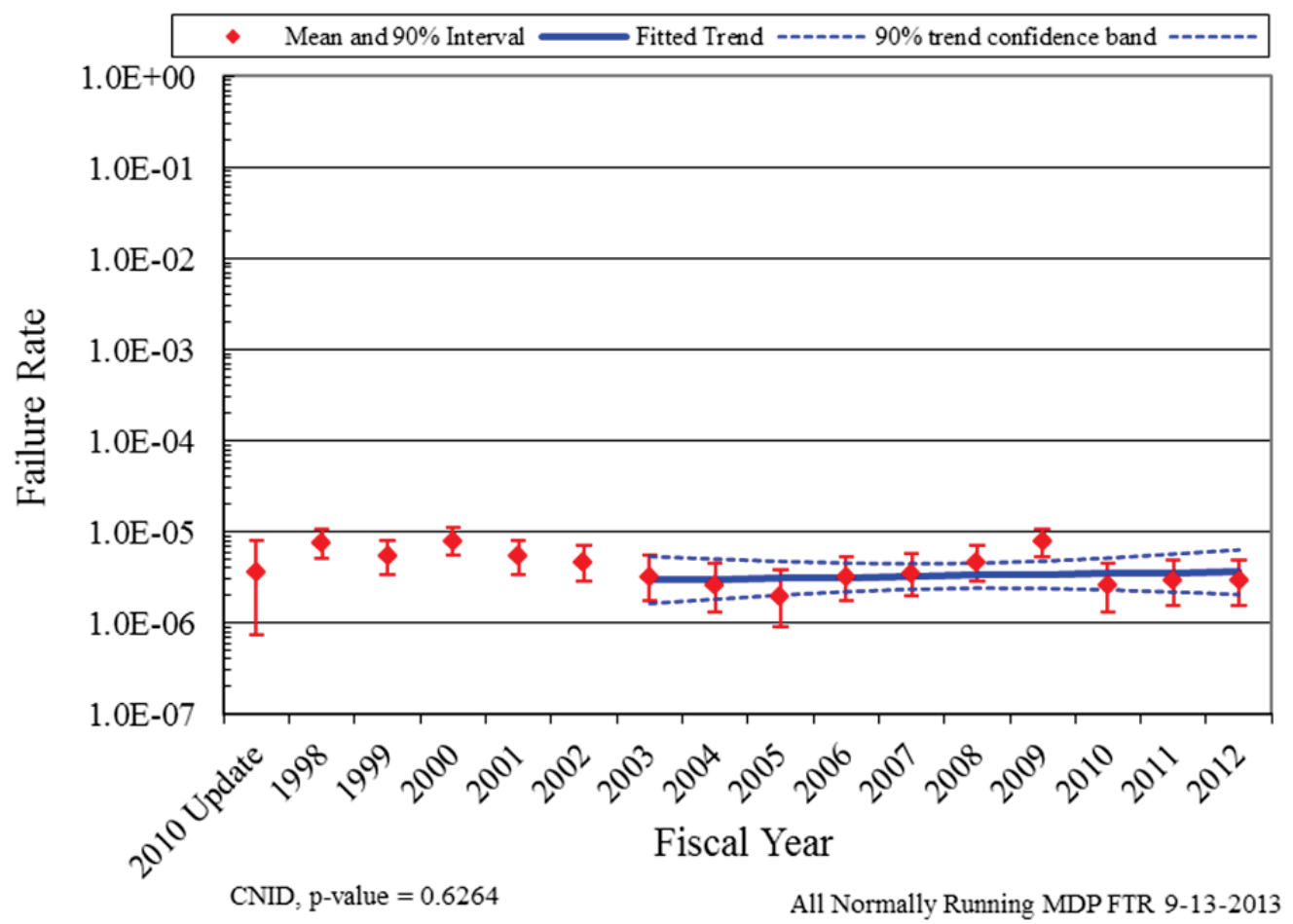

Figure 5. Failure rate estimate trend for normally running systems, industry-wide MDP FTR trend. 
In the plots, the means of the posterior distributions from the Bayesian update process were trended across the years. The posterior distributions were also used for the vertical bounds for each year. The 5th and 95th percentiles of these distributions give an indication of the relative variation from year to year in the data. When there are no failures, the interval tends to be larger than the interval for years when there are one or more failures. The larger interval reflects the uncertainty that comes from having little information in that year's data. Such uncertainty intervals are determined by the prior distribution. In each plot, a relatively "flat" constrained noninformative prior distribution (CNID) is used, which has large bounds.

The horizontal curves plotted around the regression lines in the graphs form 90 percent simultaneous confidence bands for the fitted lines. The bounds are larger than ordinary confidence intervals for the trended values because they form a band that has a $90 \%$ probability of containing the entire line. In the lower left hand corner of the trend figures, the regression p-values are reported. They come from a statistical test on whether the slope of the regression line might be zero. Low p-values indicate that the slopes are not likely to be zero, and that trends exist.

Further information on the trending methods is provided in Section 2 of the Overview and Reference document. A final feature of the trend graphs is that the baseline industry values from Table 2 are shown for comparison. 


\section{UNAVAILABILITY}

\subsection{Overview}

The industry-wide test or maintenance UA of MDP trains has been calculated from the operating experience. UA data are for MDP trains, which can include more than just the MDP. However, in most cases the MDP contributes the majority of the UA reported. Table 3 shows overall results for the MDP from Reference 1 based on UA data from MSPI Basis Documents, covering 2002 to 2010. In the calculations, planned and unplanned unavailable hours for a train are combined.

Table 3. Industry-wide distributions of unavailability for MDPs.

\begin{tabular}{lcccr}
\hline \multicolumn{1}{c}{ Description } & Mean & Distribution & $\boldsymbol{\alpha}$ & $\boldsymbol{\beta}$ \\
\hline Motor Driven Pump Test And Maintenance (AFW) & $3.63 \mathrm{E}-03$ & Beta & 2.58 & 710.22 \\
\hline Motor Driven Pump Test And Maintenance (ALL) & $7.00 \mathrm{E}-03$ & Beta & 1.08 & 153.78 \\
\hline Motor Driven Pump Test And Maintenance (CCW) & $4.79 \mathrm{E}-03$ & Beta & 1.18 & 244.83 \\
\hline Motor Driven Pump Test And Maintenance (ESW) & $1.32 \mathrm{E}-02$ & Beta & 1.00 & 74.55 \\
\hline Motor Driven Pump Test And Maintenance (HPCS) & $7.05 \mathrm{E}-03$ & Beta & 6.70 & 943.80 \\
\hline Motor Driven Pump Test And Maintenance (HPSI) & $3.45 \mathrm{E}-03$ & Beta & 2.45 & 707.96 \\
\hline Motor Driven Pump Test And Maintenance (RHR-BWR) & $5.74 \mathrm{E}-03$ & Beta & 6.23 & 1078.64 \\
\hline Motor Driven Pump Test And Maintenance (RHR-PWR) & $5.15 \mathrm{E}-03$ & Beta & 2.62 & 506.37 \\
\hline
\end{tabular}

\subsection{MDP Unavailability Trends}

For the 1998-2012 period, the following are overall maintenance unavailability data. Note that these data do not supersede the data in Table 3 for use in risk assessments.

The trend in standby MDP train unavailability is shown in Figure 6. The data for this figure is in Table 16. The MDPs in systems AFW, HPCI, and RCIC are pooled and trended (these are the systems with maintenance unavailability data currently analyzed). The trend chart shows the results of using data for each year's component unavailability data over time. The yearly (1998-2012) unavailability and reactor critical hour data were obtained from the Reactor Oversight Program (1998 to 2001) and EPIX (2002 to 2012) data for the MDP component. The total downtimes during operation for each plant and year were summed, and divided by the corresponding number of MDP-reactor critical hours. Unavailability data for shutdown periods are not reported. 


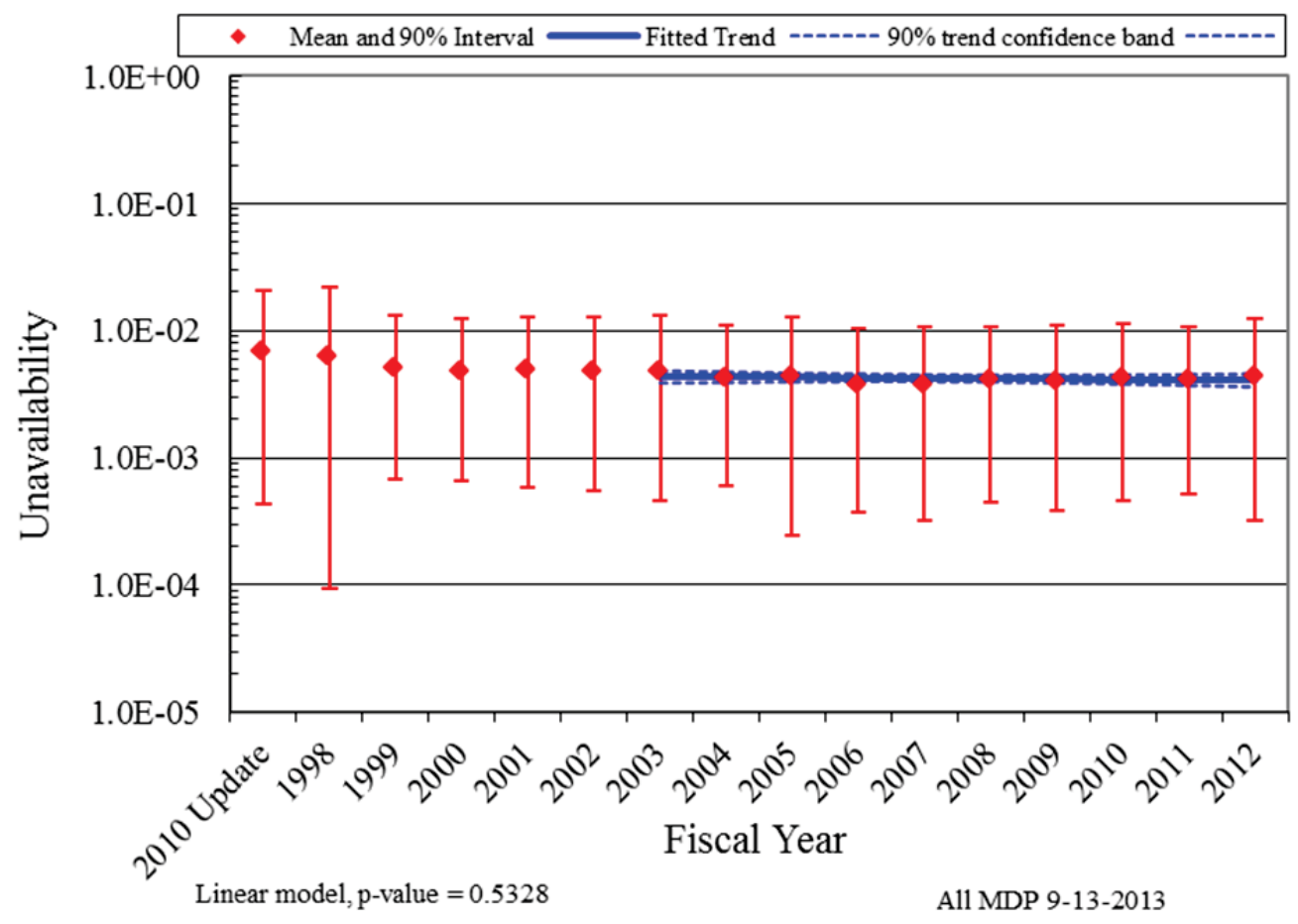

Figure 6. Pooled AFW, HPI, and HCS MDP UA trend.

The mean and variance for each year is the sample mean and variance calculated from the plant-level unavailabilities for that year. The vertical bar spans the calculated $5^{\text {th }}$ to $95^{\text {th }}$ percentiles of the beta distribution with matching means.

For the trend graphs, a least squares fit is sought for the linear or logit model. Section 3 in the Overview and Reference document provides further information. In the lower left hand corner of the trend figures, the p-value is reported. 


\section{MDP UNRELIABILITY TRENDS}

Trends in total component unreliability are shown in Figure 7 and Figure 8. Plot data for these figures are in Table 17 and Table 18, respectively. Total unreliability is defined as the result of an OR gate with the FTS, FTR $\leq 1 \mathrm{H}, \mathrm{FTR}>1 \mathrm{H}$ (or FTR), and UA as basic event inputs. The FTR $>1 \mathrm{H}$ is calculated for 7 hours and the FTR is calculated for 8 hours to provide the results for an 8-hour mission. Since the normally running systems MDP components do not have UA data or the FTR $\leq 1 \mathrm{H}$ data, there is no UA or FTR $\leq 1 \mathrm{H}$ input to the OR gate for that calculation. The trending method is described in more detail in Section 4 of the Overview and Reference document. In the lower left hand corner of the trend figures, the regression method is reported.

The standby systems from Table 2 are trended together and shown in Figure 7. The normally running systems from Table 2 are trended together and shown in Figure 8.

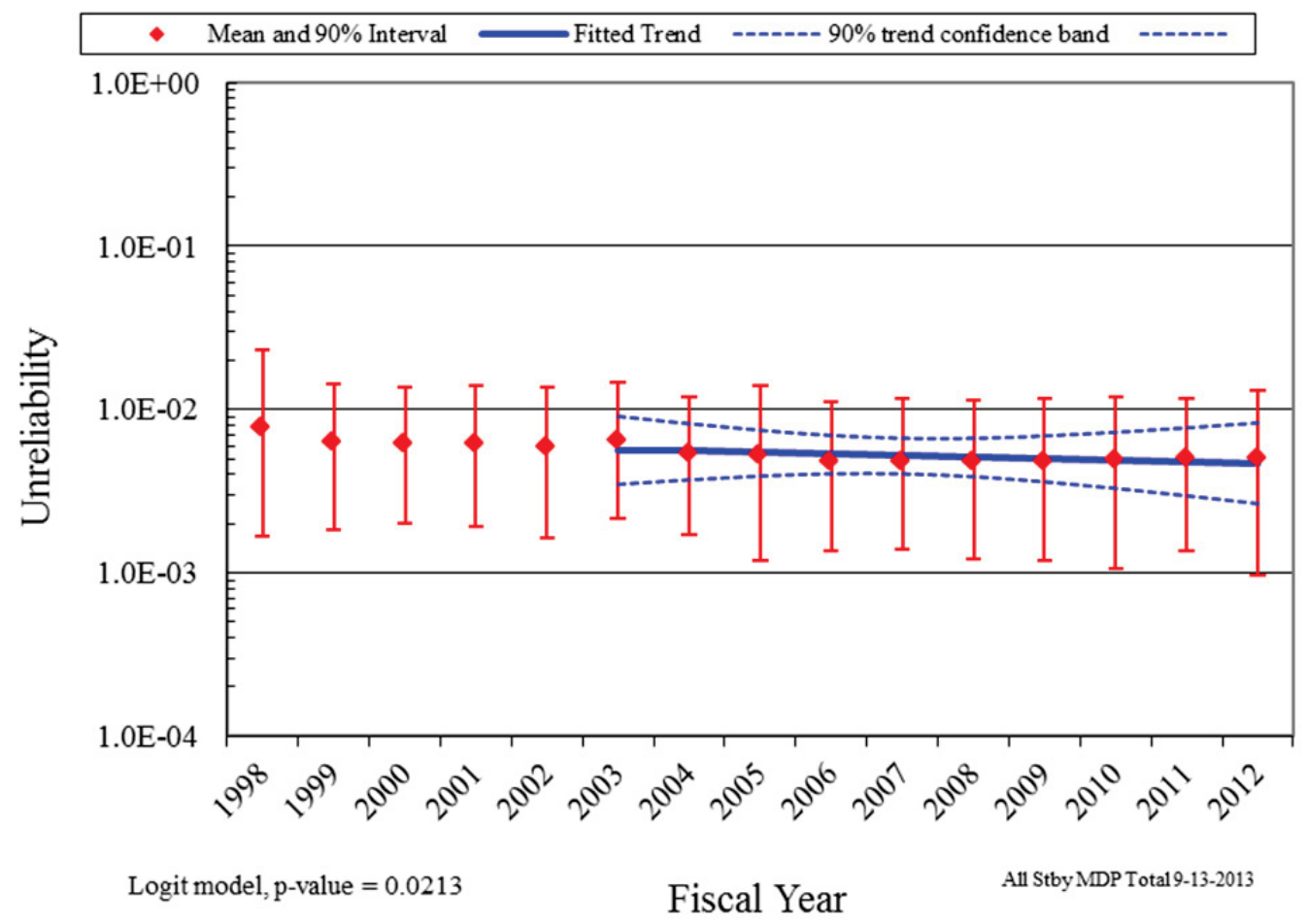

Figure 7. Standby systems, industry-wide MDP unreliability trend (8-hour mission). 


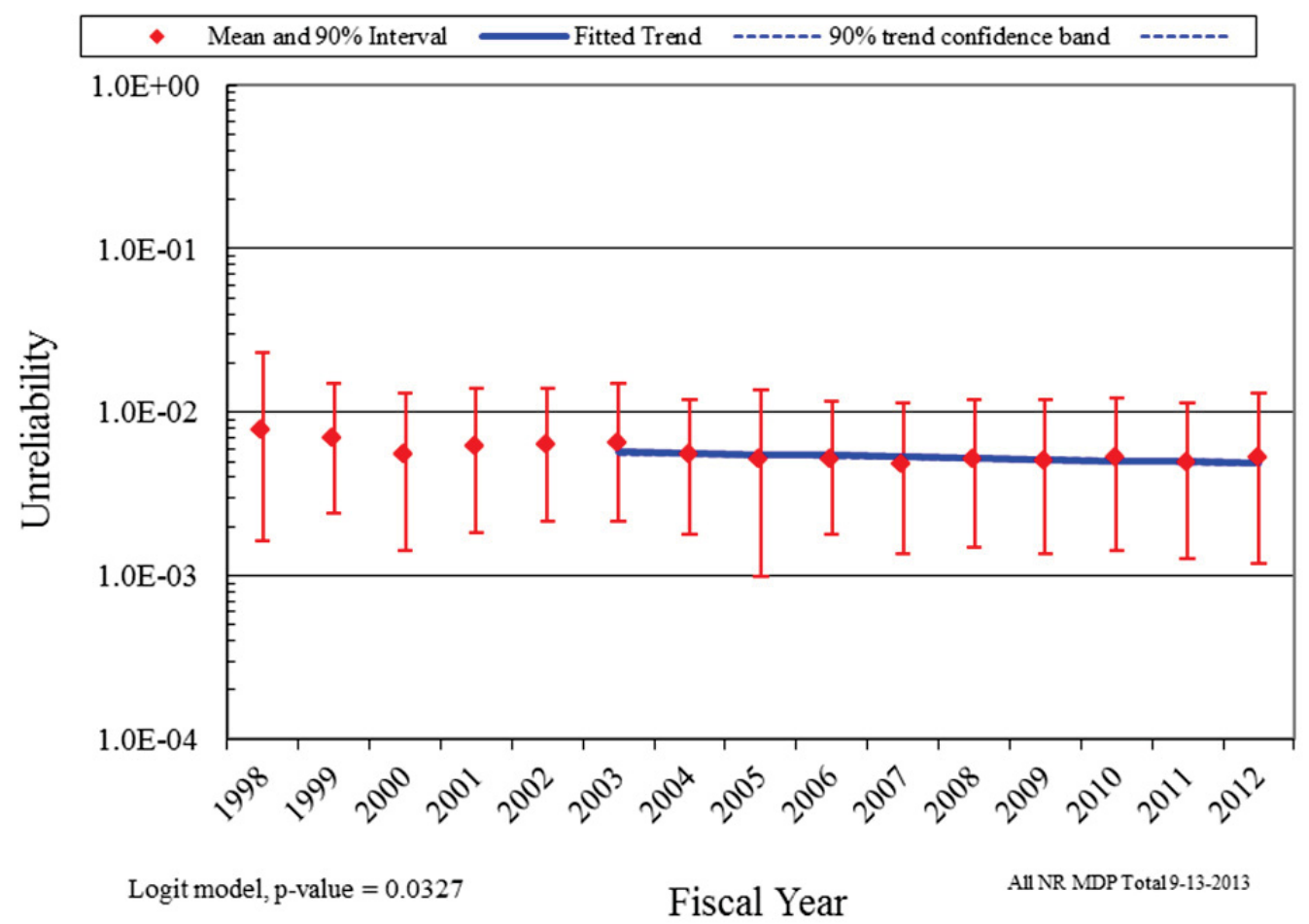

Figure 8. Normally running systems (MFW), industry-wide MDP unreliability trend (8-hour mission). 


\section{ENGINEERING TRENDS}

This section presents frequency trends for MDP failures and demands. The data are normalized by reactor year for plants that have the equipment being trended. The rate methods described in Section 2 of the Overview and Reference document are used.

\subsection{Standby MDP Engineering Trends}

Figure 9 shows the trend for standby MDP start demands. Figure 10 shows the trend MDP run $\leq 1$ hour demands. Figure 11 shows the trend for the MDP run hours. Table 19, Table 20, and Table 21 provide the plot data, respectively.

Figure 12 shows the trend for MDP FTS events. Figure 13 shows the trend MDP FTR $\leq 1 \mathrm{H}$ events, and Figure 14 shows the trend for the MDP FTR events. Table 22, Table 24, and Table 25 provide the plot data, respectively. The standby systems from Table 2 are trended together for each figure.

Table 4 summarizes the failures by system and year for the FTS failure mode.

Table 5 summarizes the failures by system and year for the FTR $\leq 1 \mathrm{H}$ failure mode. Table 5 summarizes the failures by system and year for the FTR $>1 \mathrm{H}$ failure mode. The bold values in the percent of total failures column show the contributors that make up at least $50 \%$ of the failures. Tables $4-6$ only include systems where failures of that failure mode have been detected.

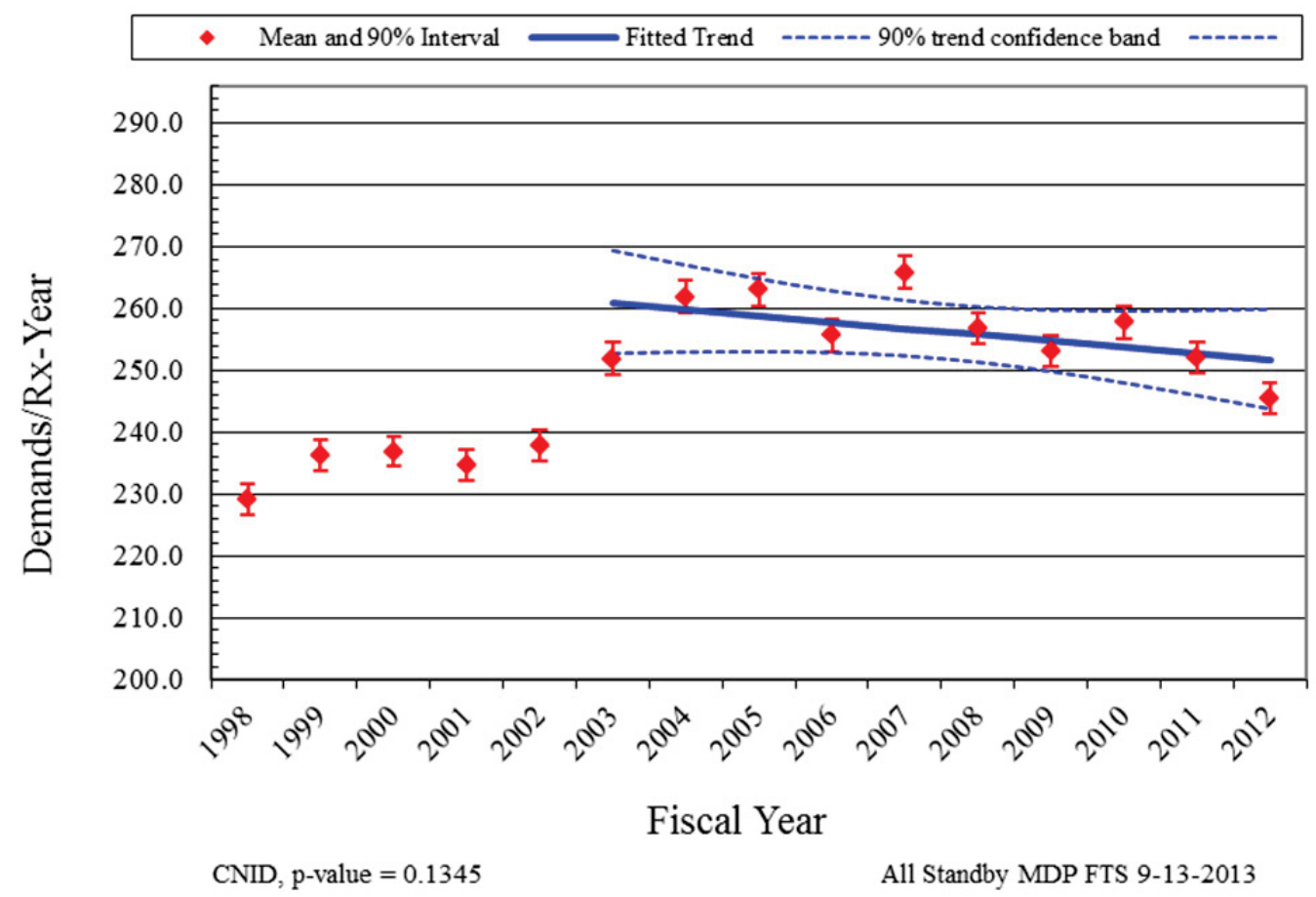

Figure 9. Frequency (demands per reactor year) of start demands, standby MDPs. 


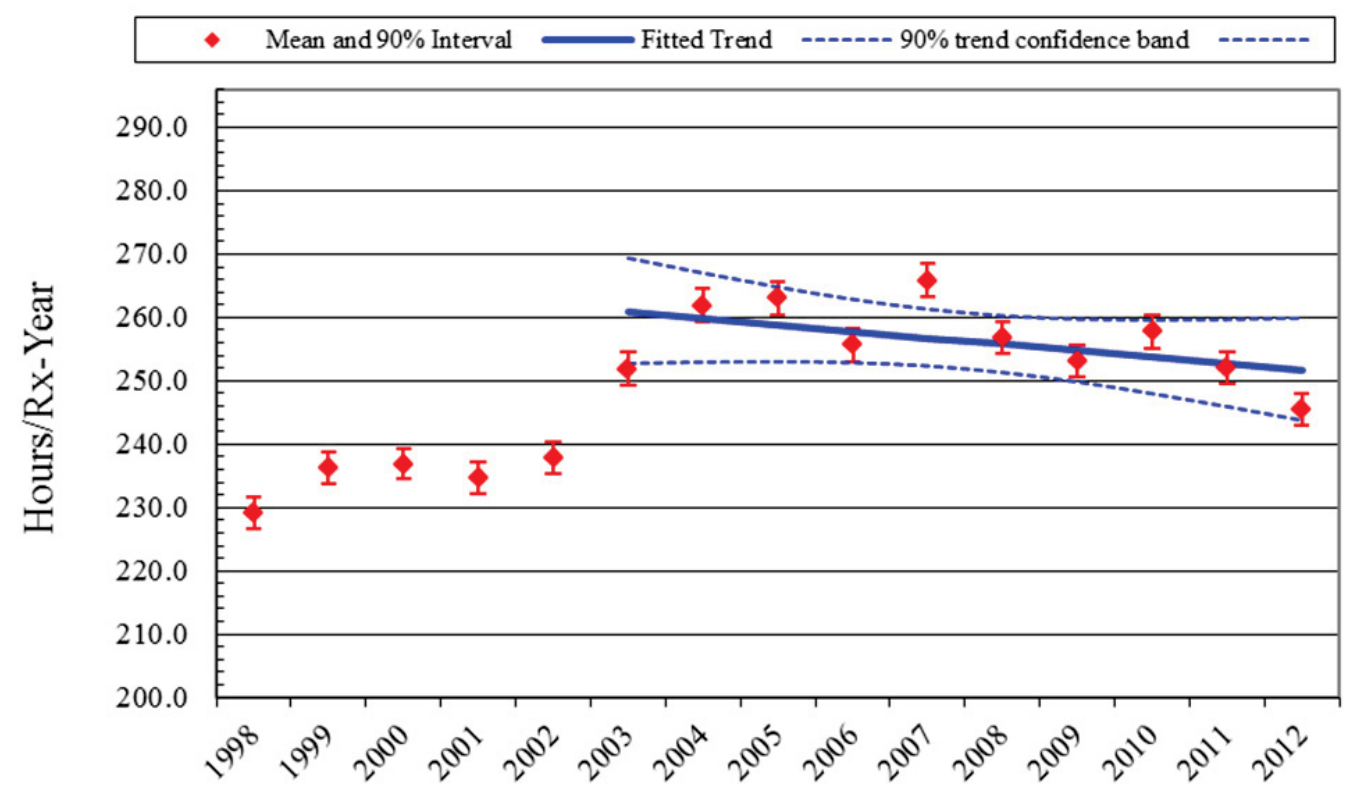

Fiscal Year

CNID, $\mathrm{p}$-value $=0.1345$

All Standby MDP FTR<1H 9-13-2013

Figure 10. Standby MDP run hours per reactor critical year of run $\leq 1 \mathrm{H}$ hours.

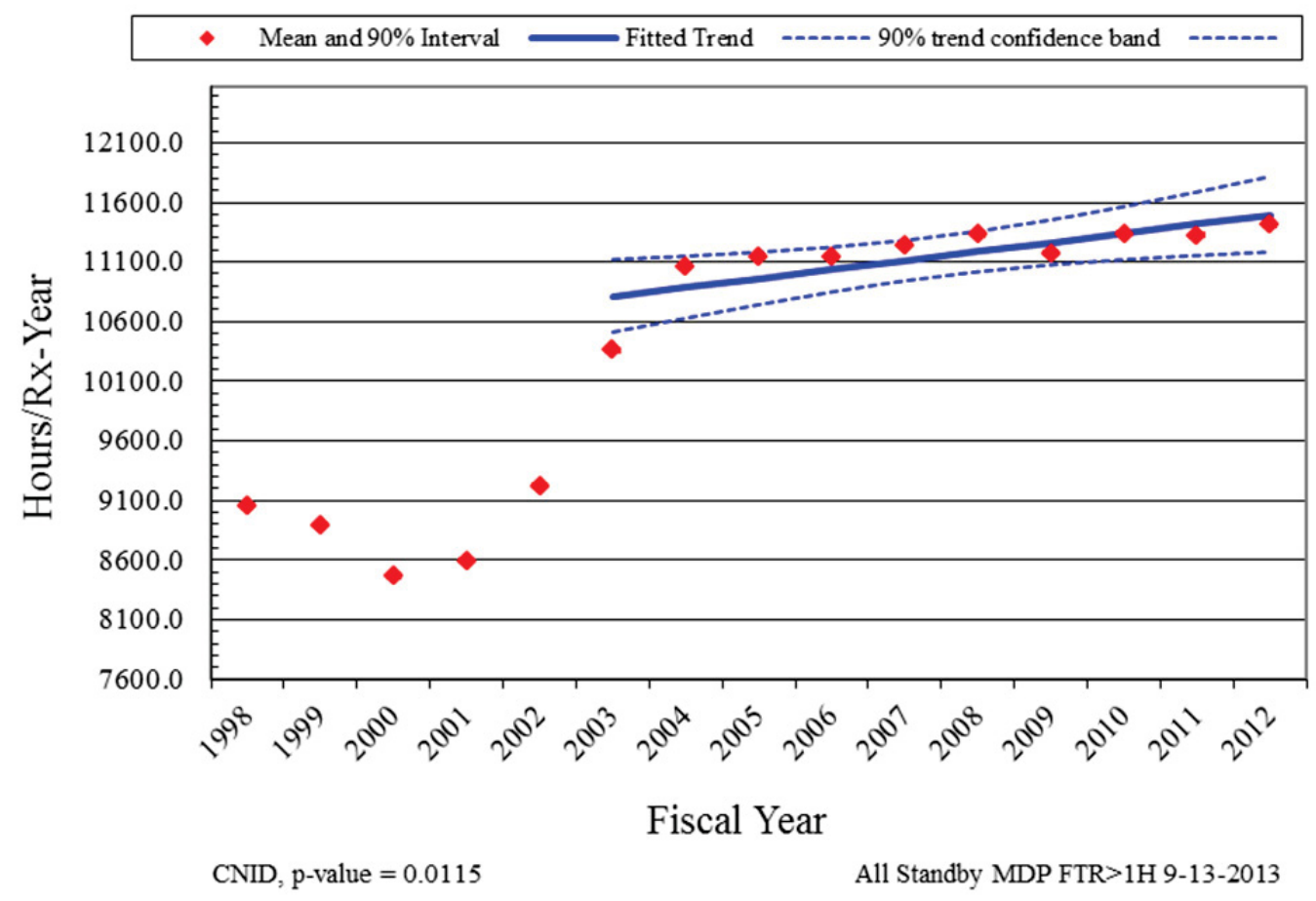

Figure 11. Standby MDP run hours per reactor critical year. 


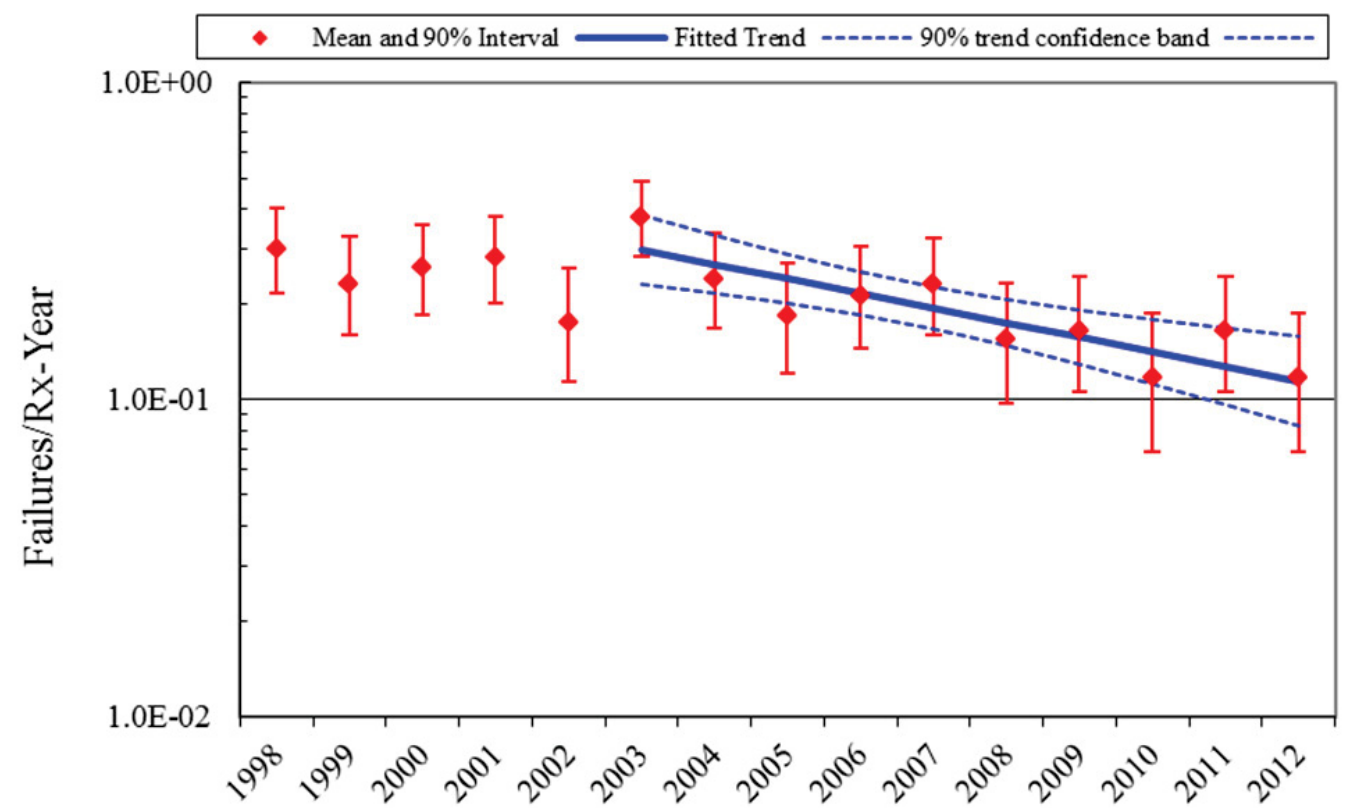

Fiscal Year

CNID, p-value $=0.0012$

All Standby MDP FTS 9-13-2013

Figure 12. Frequency (failures per reactor year) of FTS events, standby MDPs.

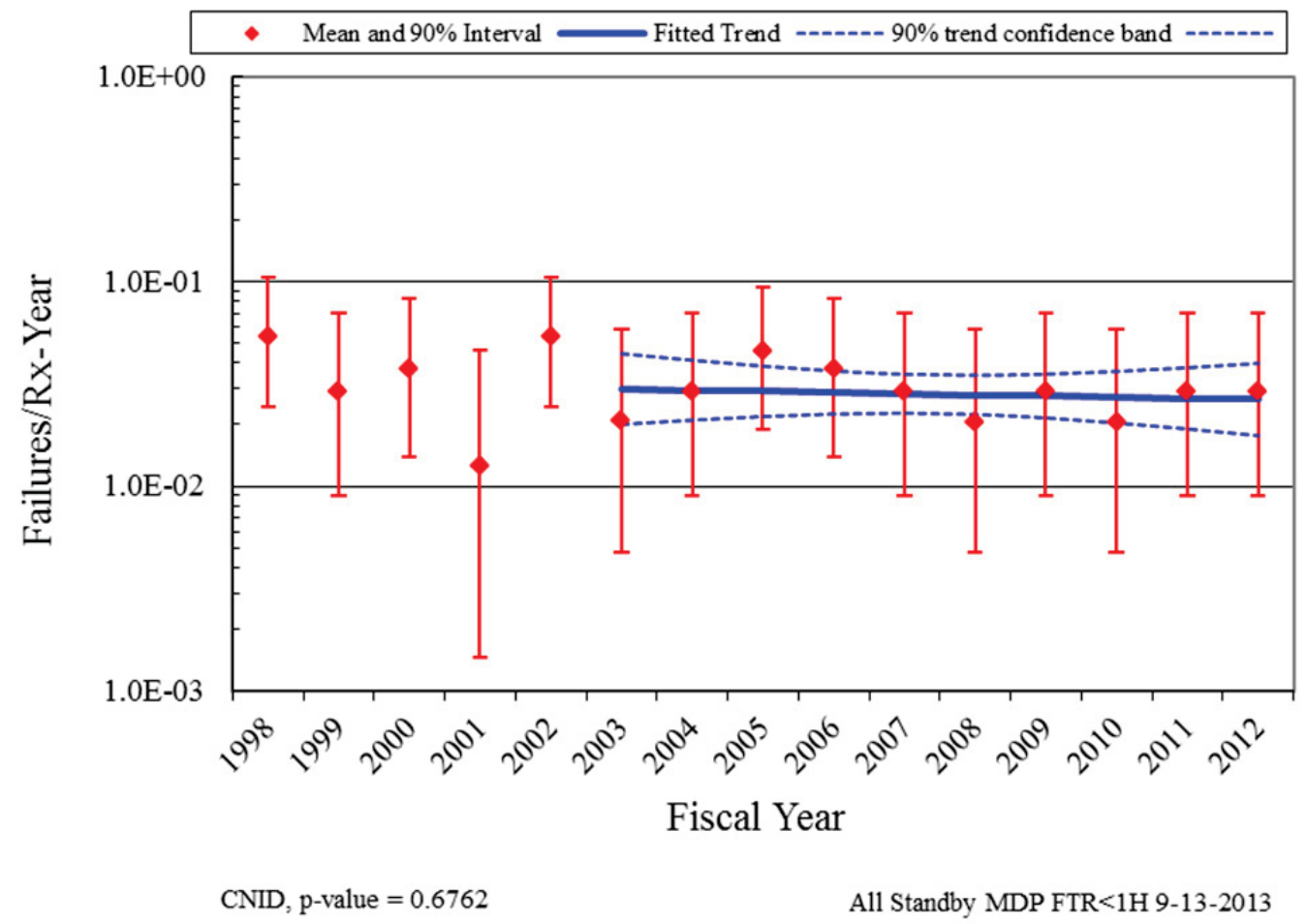

Figure 13. Frequency (failures per reactor year) of $\mathrm{FTR} \leq 1 \mathrm{H}$ events, standby MDPs. 


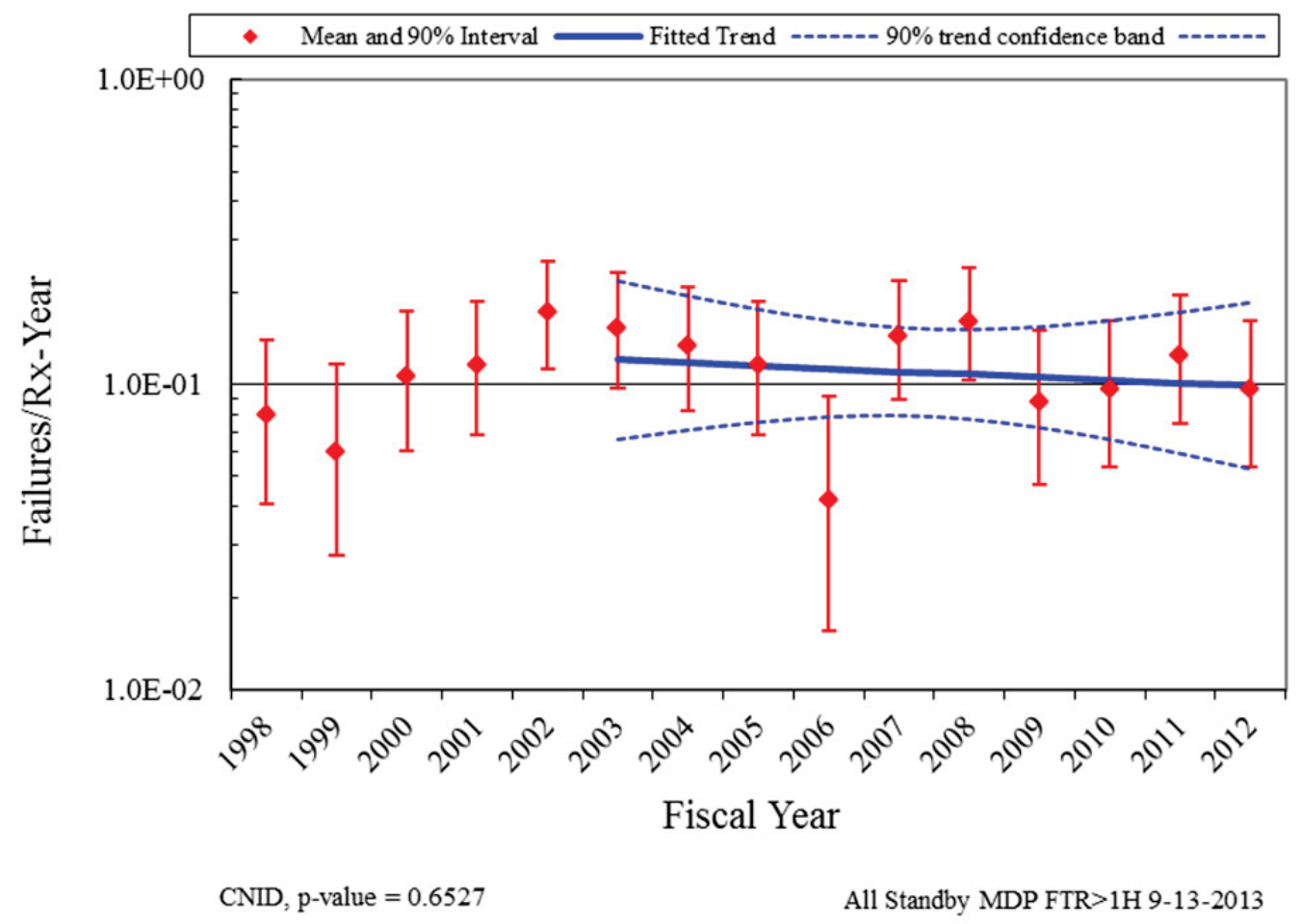

Figure 14. Frequency (failures per reactor year) of FTR $>1 \mathrm{H}$ events, standby MDPs.

\subsection{Normally Running MDP Engineering Trends}

Figure 15 shows the trend for normally running MDP demands and Figure 16 shows the trend for the MDP run hours. Table 25 and Table 26 provide the plot data, respectively.

Figure 17 shows the trend for MDP FTS events and Figure 18 shows the trend for the MDP FTR events. Table 27 and Table 28 provide the plot data respectively. The normally running systems from Table 2 are trended for each figure.

Table 7 summarizes the failures by system and year for the FTS failure mode. Table 8 summarizes the failures by system and year for the FTR failure mode. The bold values in the percent of total failures column show the contributors that make up at least $50 \%$ of the failures. 


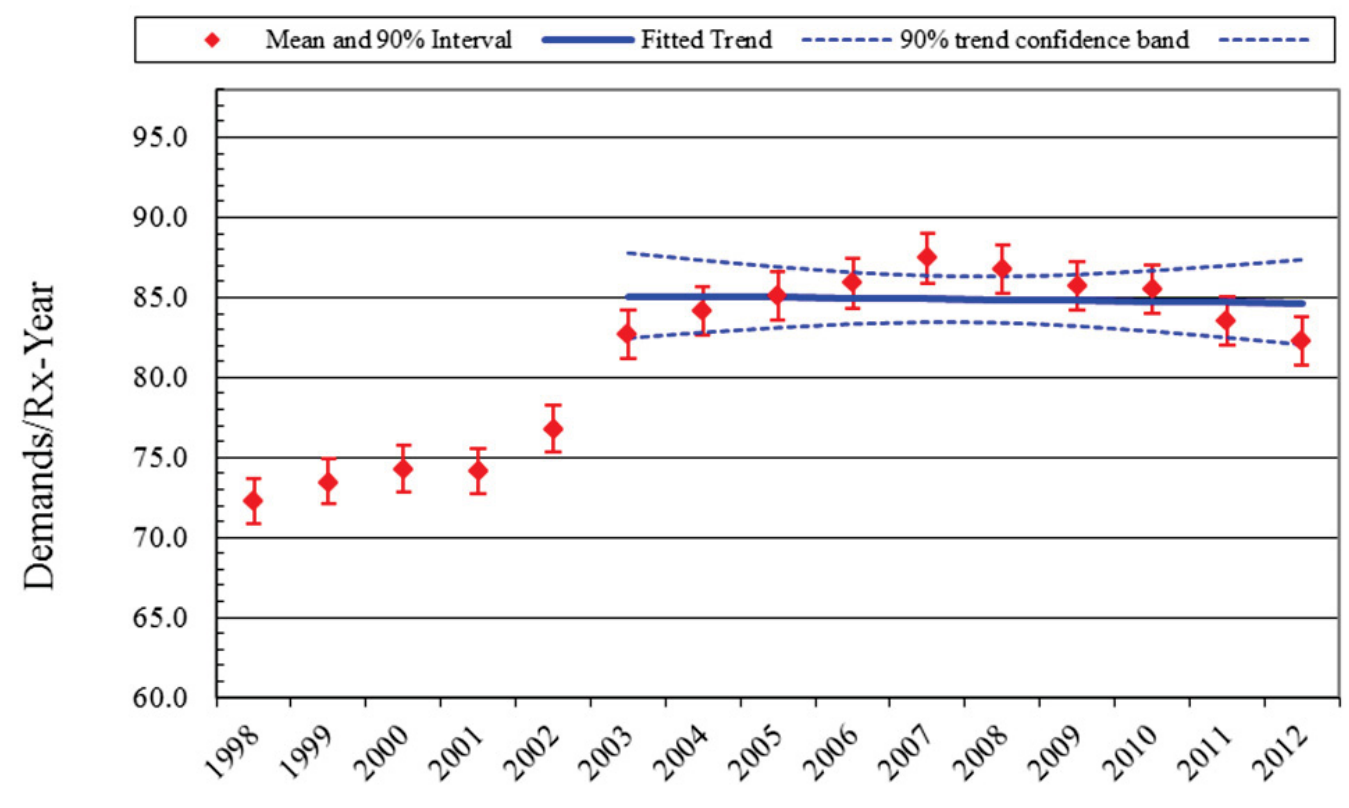

Fiscal Year

CNID, p-value $=0.8226$

All Normally Running MDP FTS 9-13-2013

Figure 15. Frequency (demands per reactor year) of start demands, normally running MDPs.

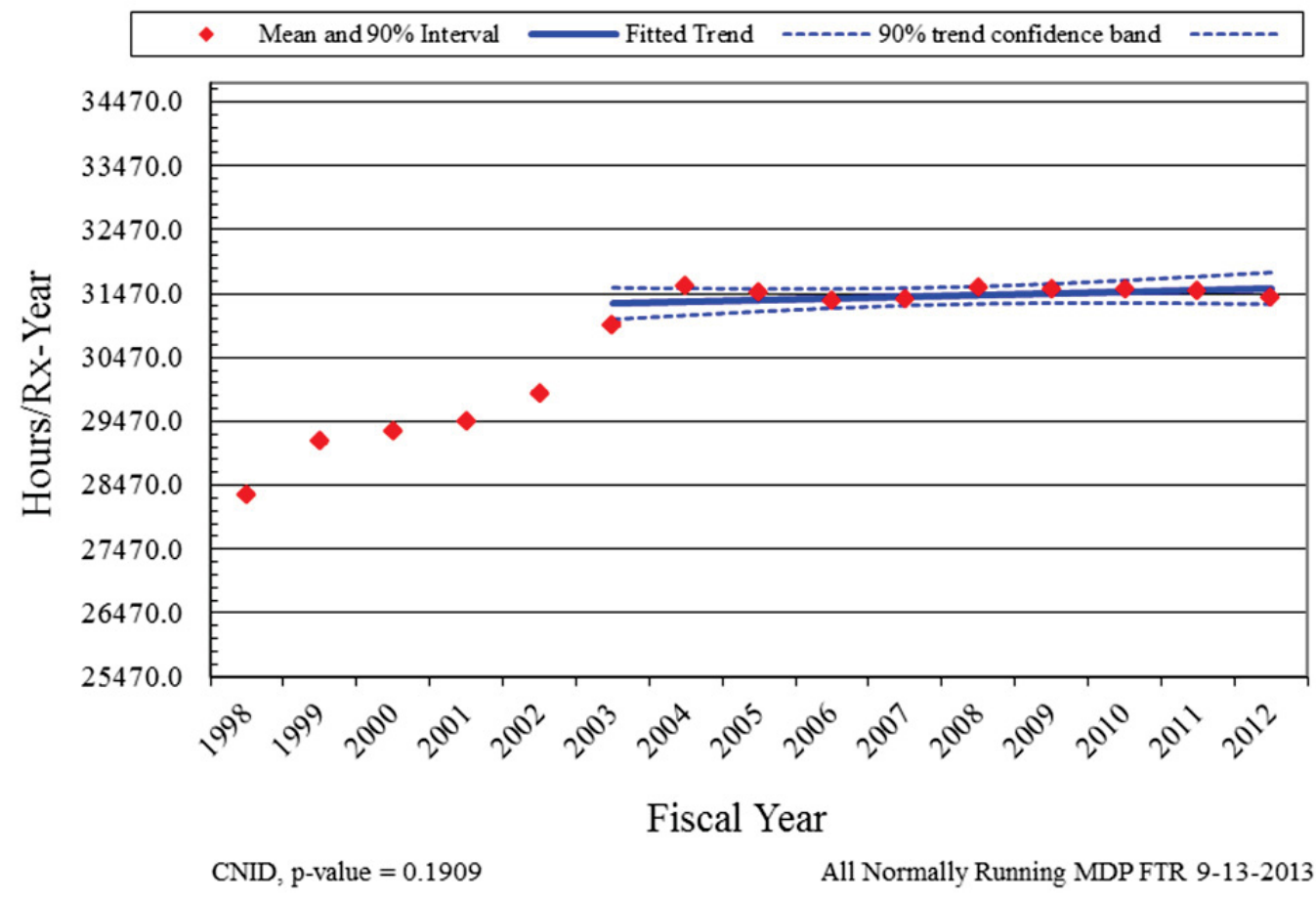

Figure 16. Normally running MDP run hours per reactor critical year. 


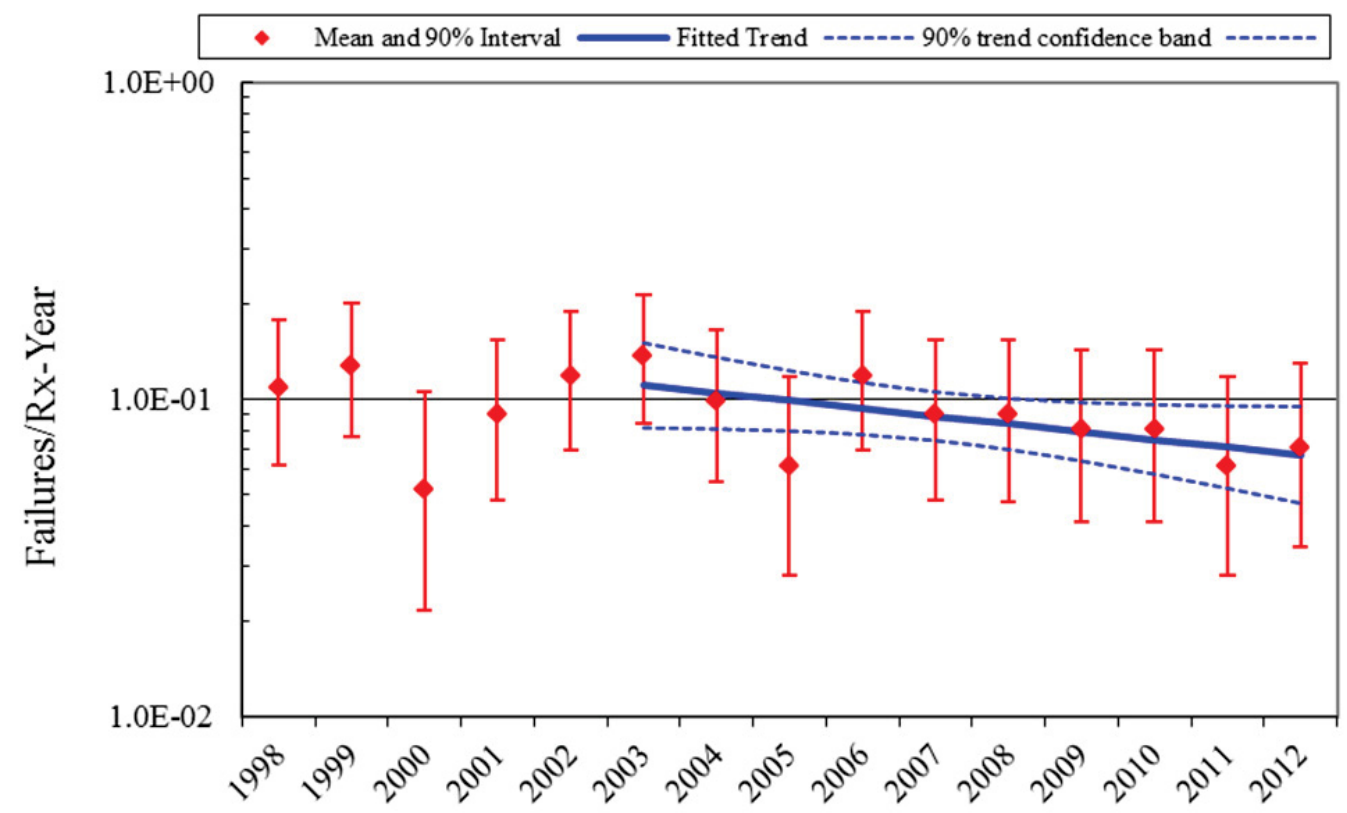

Fiscal Year

CNID, p-value $=0.0535$

All Normally Running MDP FTS 9-13-2013

Figure 17. Frequency (failures per reactor year) of FTS events, normally running MDPs.

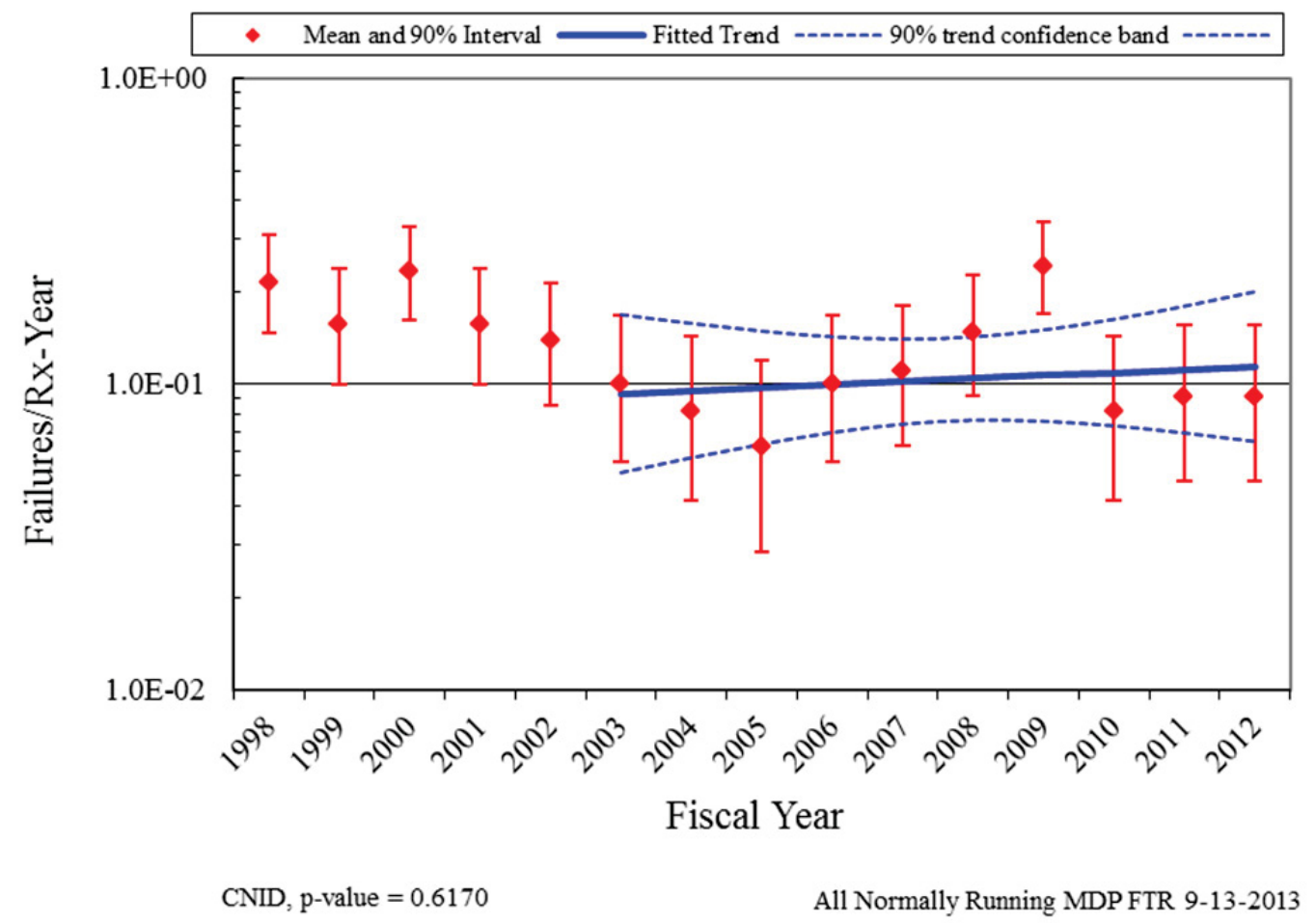

Figure 18. Frequency (failures per reactor year) of FTR events, normally running MDPs. 


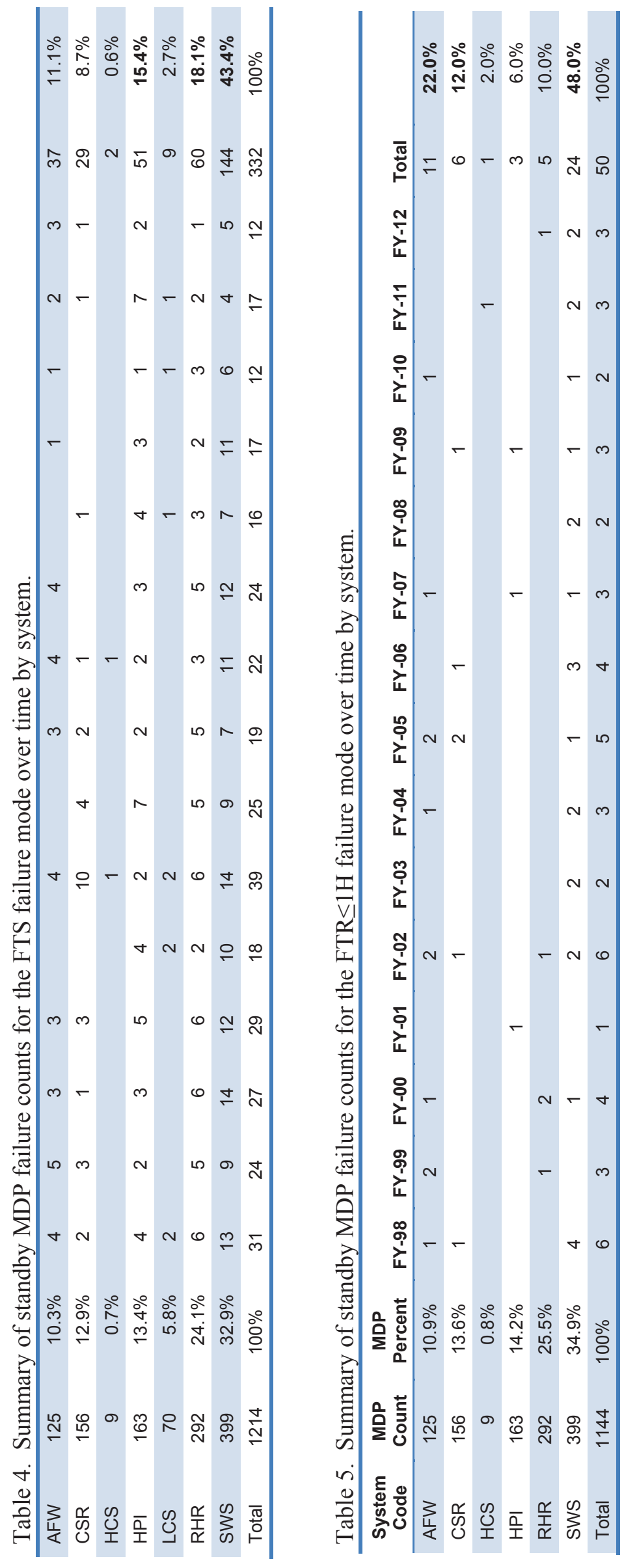

Enhanced Component Performance Study

Motor-Driven Pumbs

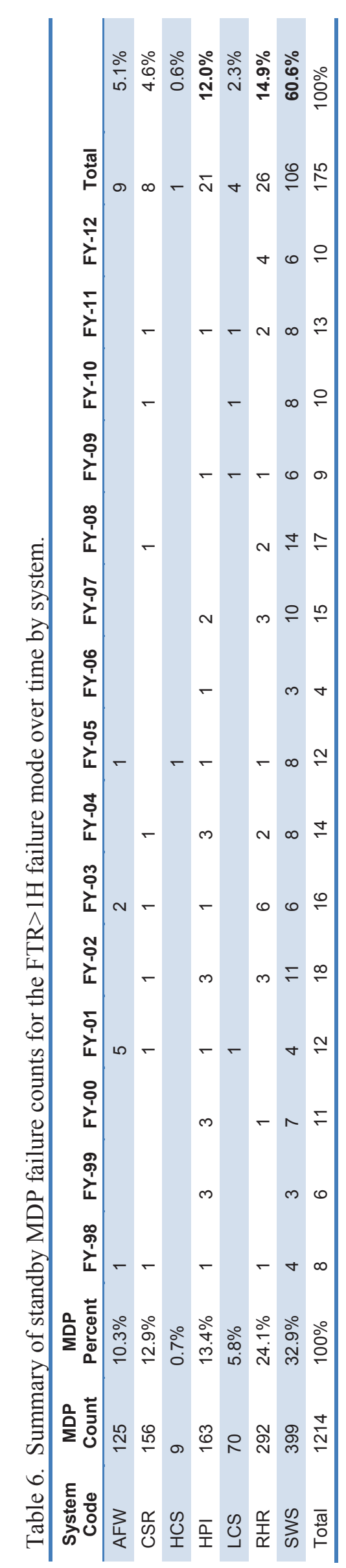



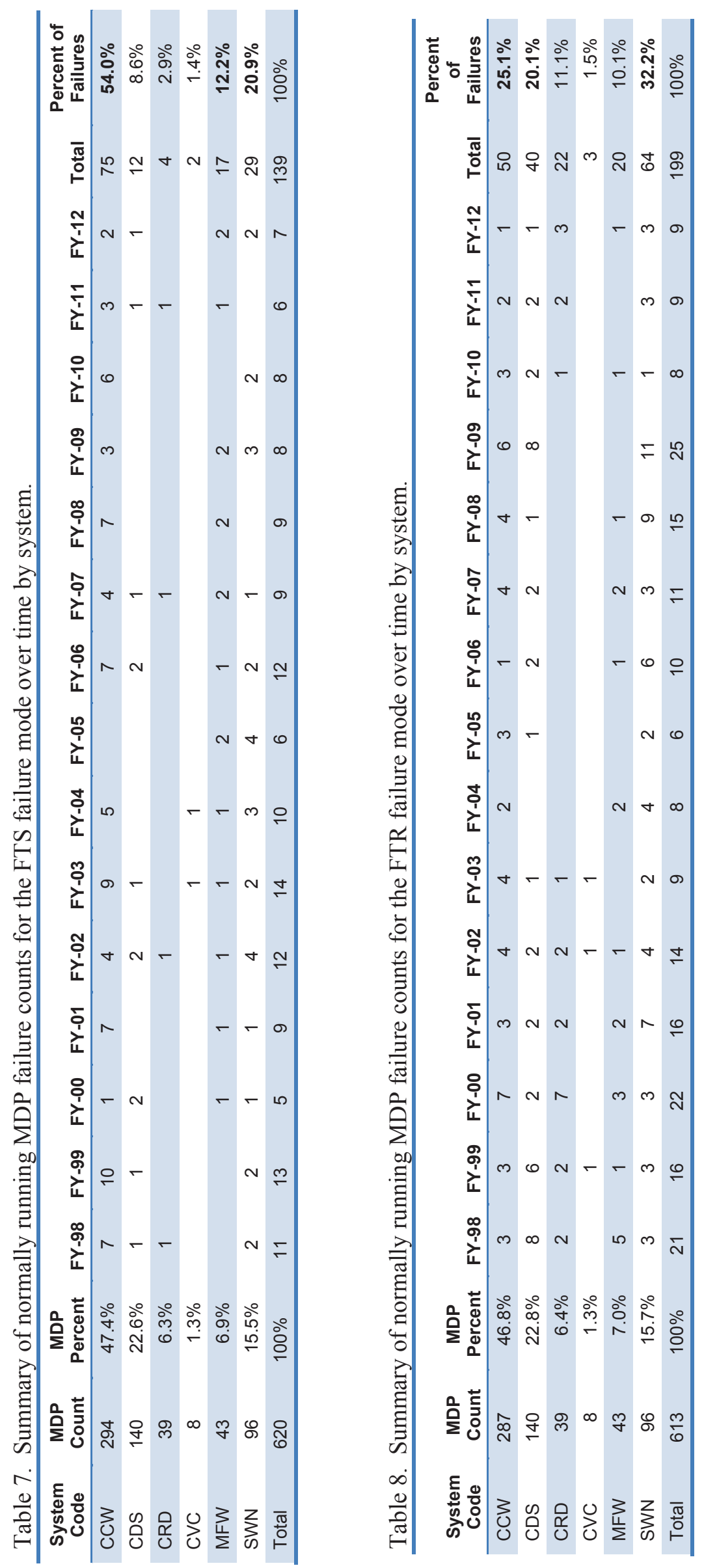

Enhanced Component Performance Study 


\subsection{Comparison of EPIX MDP Unplanned Demand Results with Industry Results for Standby Components}

An ongoing concern in the industry is whether a combination of test, non-test demand, and actual demand data adequately represents standby component performance during unplanned demands. This comparison evaluates the same dataset for standby components that is used for the overall trends shown in this document, but limits the failure data to those that are discovered during an ESF demand and the ESF demands reported in EPIX. The data are further limited to FY 2003 to present since the ESF demand reporting in EPIX is inconsistent prior to FY 2003.

The standby MDP ESF unplanned demand data covering FY 2003 - 2012 are summarized in Table 9. Consistency between the unplanned demand data and industry-average performance from Table 2 was evaluated using the predictive distribution approach outlined in the Handbook of Parameter Estimation for Probabilistic Risk Assessment, NUREG/CR-6823, Sections 6.2.3.5 and 6.3.3.4 [Reference 3].

The unplanned demand data were aggregated at the plant and system level (failures and demands). Assuming each plant and system can have a different failure probability, the industry-average distribution (from Table 2) was sampled for each plant and system. The predicted number of failure events for each plant and system was evaluated using the binomial distribution with the plant-specific failure probability and its associated number of demands. Then the total number of predicted failures was obtained by summing the individual plant results. This process was repeated 1000 times (Latin hypercube sampling), each time obtaining a total number of predicted failures. The 1000 sample results were ordered from high to low. Then the actual number of unplanned demand failures observed (listed in Table 9) was compared with this ordered sample to determine the probability of observing this number of failures or greater. If the probability was greater than 0.05 and less than 0.95 , then the unplanned demand performance was considered to be consistent with the industry-average distribution obtained from the EPIX data analysis.

Table 9. Standby MDP unplanned demand performance comparison with industry-average performance.

\begin{tabular}{lclcccc}
\hline \multicolumn{1}{c}{ Failure Modes } & Plants & $\begin{array}{c}\text { Demands or } \\
\text { Hours }\end{array}$ & Failures & $\begin{array}{c}\text { Expected } \\
\text { Failures }\end{array}$ & $\begin{array}{c}\text { Probability of } \\
\geq \text { Failures }\end{array}$ & $\begin{array}{c}\text { Consistent with } \\
\text { Industry-Average } \\
\text { Performance? }\end{array}$ \\
\hline FTS & 104 & 1151 & 1 & 1.1 & 0.001 & No \\
FTR $<1 \mathrm{H}$ & 104 & 798 & 0 & 0.1 & 1.000 & No \\
FTR $>1 \mathrm{H}$ & 104 & 18704 & 0 & 1.5 & 1.000 & No \\
Total MDP & 104 & 1,151 and & 1 & 2.7 & 0.001 & \\
Unreliability (8 hr) & & $18,703.8 \mathrm{hr}$ & & & & \\
\hline
\end{tabular}

The consistency checks using unplanned demand data indicate that none of the failure observations are consistent with their industry-average distribution from Table 2. The FTS, FTR $<1 \mathrm{H}, \mathrm{FTR}>1 \mathrm{H}$, and Total UR observations are superior (smaller) than the industry average distribution.

\subsection{MDP Engineering Analysis by Failure Modes}

The engineering analysis of the standby MDP failure sub-components, causes, detection methods, and recovery possibility are presented in this section. First, each analysis divides the events into two categories: Standby and Normally running MDPs. Note that the FTR $<1 \mathrm{H}$ failure mode only applies to standby MDPs and therefore only shows the Standby category data.

The second division of the events is by the failure mode determined after EPIX data review by the staff. See Section 7 for more description of failure modes. 
MDP sub-component contributions to the three failure modes are presented in Figure 19. The subcomponent contributions are similar to those used in the CCF database. The driver has the highest percentage contributions to failures for the fail to start failure mode.

The pump sub-component is the highest for the FTR $\leq 1 \mathrm{H}$ failure mode followed closely by the driver.

For the FTR $>1 \mathrm{H}$ failure mode there is a difference in importance between the standby and normally running categories. The standby category has the pump as the highest contributor and the normally running has the driver as the highest contributor.

MDP cause group contributions to the three failure modes are presented in Figure 20. The cause groups are similar to those used in the CCF database. Table 10 shows the breakdown of the cause groups with the specific causes that were coded during the data collection. The most likely causes are internal faults, human errors, and design issues. Internal means that the cause was related to something within the MDP component such as a worn out part or the normal internal environment. The human cause group is primarily influenced by maintenance and operating procedures and practices. The design cause group is influenced by manufacturing, installation, and design issues.

MDP detection methods to the three failure modes are presented in Figure 21. There are differences in the detection method based on the Standby and normally running categories.

Standby - the most likely detection method for FTR $<1 \mathrm{H}$ and FTR $>1 \mathrm{H}$ is non-testing. The prevalent FTS detection is test demands.

Normally running - the most likely detection method for FTR is non-testing. The prevalent FTS detection is non-test demands.

MDP recovery to the three failure modes are presented in Figure 22. The overall non-recovery to recovery ratio is approximately $7: 1$. 
Table 10. Component failure cause groups.

\begin{tabular}{|c|c|c|}
\hline Group & Specific Cause & Description \\
\hline Design & $\begin{array}{l}\text { Construction/installation } \\
\text { error or inadequacy }\end{array}$ & $\begin{array}{l}\text { Used when a construction or installation error is made } \\
\text { during the original or modification installation. This } \\
\text { includes specification of incorrect component or material. }\end{array}$ \\
\hline Design & $\begin{array}{l}\text { Design error or } \\
\text { inadequacy }\end{array}$ & Used when a design error is made. \\
\hline Design & $\begin{array}{l}\text { Manufacturing error or } \\
\text { inadequacy }\end{array}$ & $\begin{array}{l}\text { Used when a manufacturing error is made during } \\
\text { component manufacture. }\end{array}$ \\
\hline External & State of other component & $\begin{array}{l}\text { Used when the cause of a failure is the result of a } \\
\text { component state that is not associated with the } \\
\text { component that failed. An example would be the diesel } \\
\text { failed due to no fuel in the fuel storage tanks. }\end{array}$ \\
\hline External & $\begin{array}{l}\text { Ambient environmental } \\
\text { stress }\end{array}$ & $\begin{array}{l}\text { Used when the cause of a failure is the result of an } \\
\text { environmental condition from the location of the } \\
\text { component. }\end{array}$ \\
\hline Human & $\begin{array}{l}\text { Accidental action } \\
\text { (unintentional or undesired } \\
\text { human errors) }\end{array}$ & $\begin{array}{l}\text { Used when a human error (during the performance of an } \\
\text { activity) results in an unintentional or undesired action. }\end{array}$ \\
\hline Human & Human action procedure & $\begin{array}{l}\text { Used when the procedure is not followed or the procedure } \\
\text { is incorrect. For example: when a missed step or incorrect } \\
\text { step in a surveillance procedure results in a component } \\
\text { failure. }\end{array}$ \\
\hline Human & Inadequate maintenance & $\begin{array}{l}\text { Used when a human error (during the performance of } \\
\text { maintenance) results in an unintentional or undesired } \\
\text { action. }\end{array}$ \\
\hline Internal & $\begin{array}{l}\text { Internal to component, } \\
\text { piece-part }\end{array}$ & $\begin{array}{l}\text { Used when the cause of a failure is a non-specific result of } \\
\text { a failure internal to the component that failed other than } \\
\text { aging or wear. }\end{array}$ \\
\hline Internal & Internal environment & $\begin{array}{l}\text { The internal environment led to the failure. Debris/Foreign } \\
\text { material as well as an operating medium chemistry issue. }\end{array}$ \\
\hline Internal & Setpoint drift & $\begin{array}{l}\text { Used when the cause of a failure is the result of setpoint } \\
\text { drift or adjustment. }\end{array}$ \\
\hline Internal & Age/Wear & $\begin{array}{l}\text { Used when the cause of the failure is a non-specific aging } \\
\text { or wear issue. }\end{array}$ \\
\hline Other & Unknown & Used when the cause of the failure is not known. \\
\hline Other & $\begin{array}{l}\text { Other (stated cause does } \\
\text { not fit other categories) }\end{array}$ & $\begin{array}{l}\text { Used when the cause of a failure is provided but it does } \\
\text { not meet any one of the descriptions. }\end{array}$ \\
\hline Procedure & Inadequate procedure & $\begin{array}{l}\text { Used when the cause of a failure is the result of an } \\
\text { inadequate procedure operating or maintenance. }\end{array}$ \\
\hline
\end{tabular}



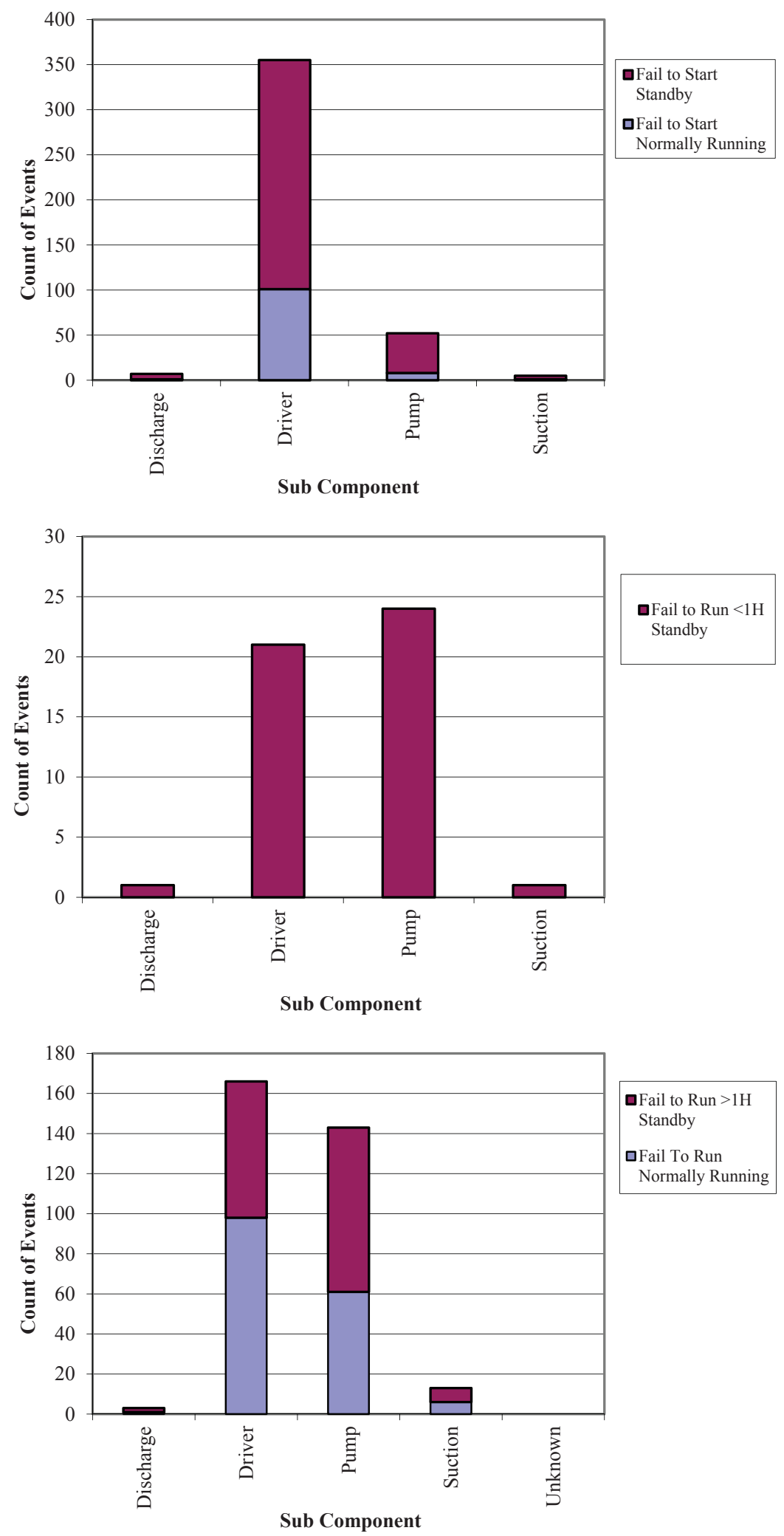

Figure 19. MDP failure breakdown by period, sub component, and failure mode. 

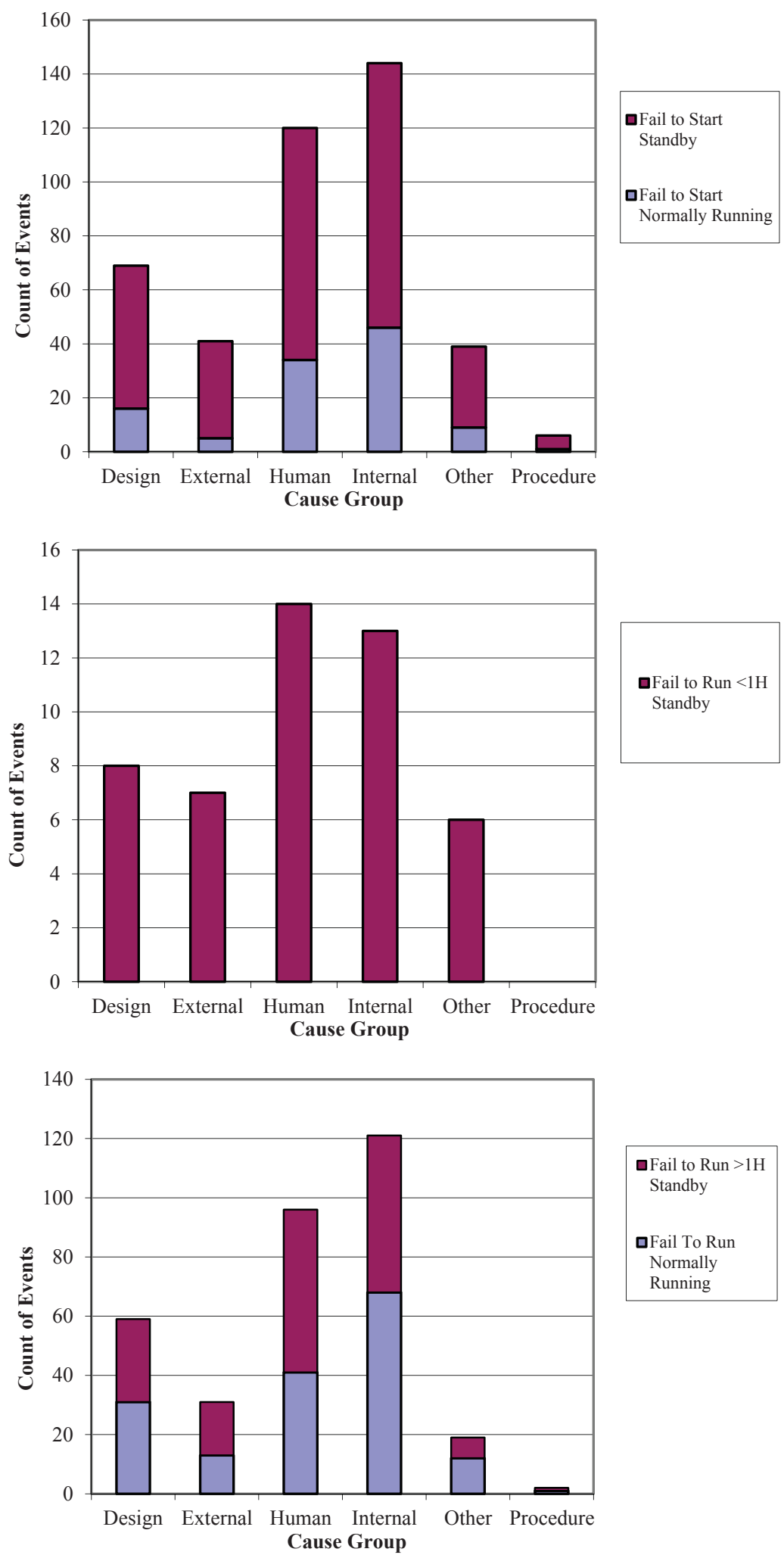

$\square$ Fail to Run $>1 \mathrm{H}$ Standby

口Fail To Run

Normally

Running

Figure 20. MDP breakdown by time period, cause group, and failure mode. 

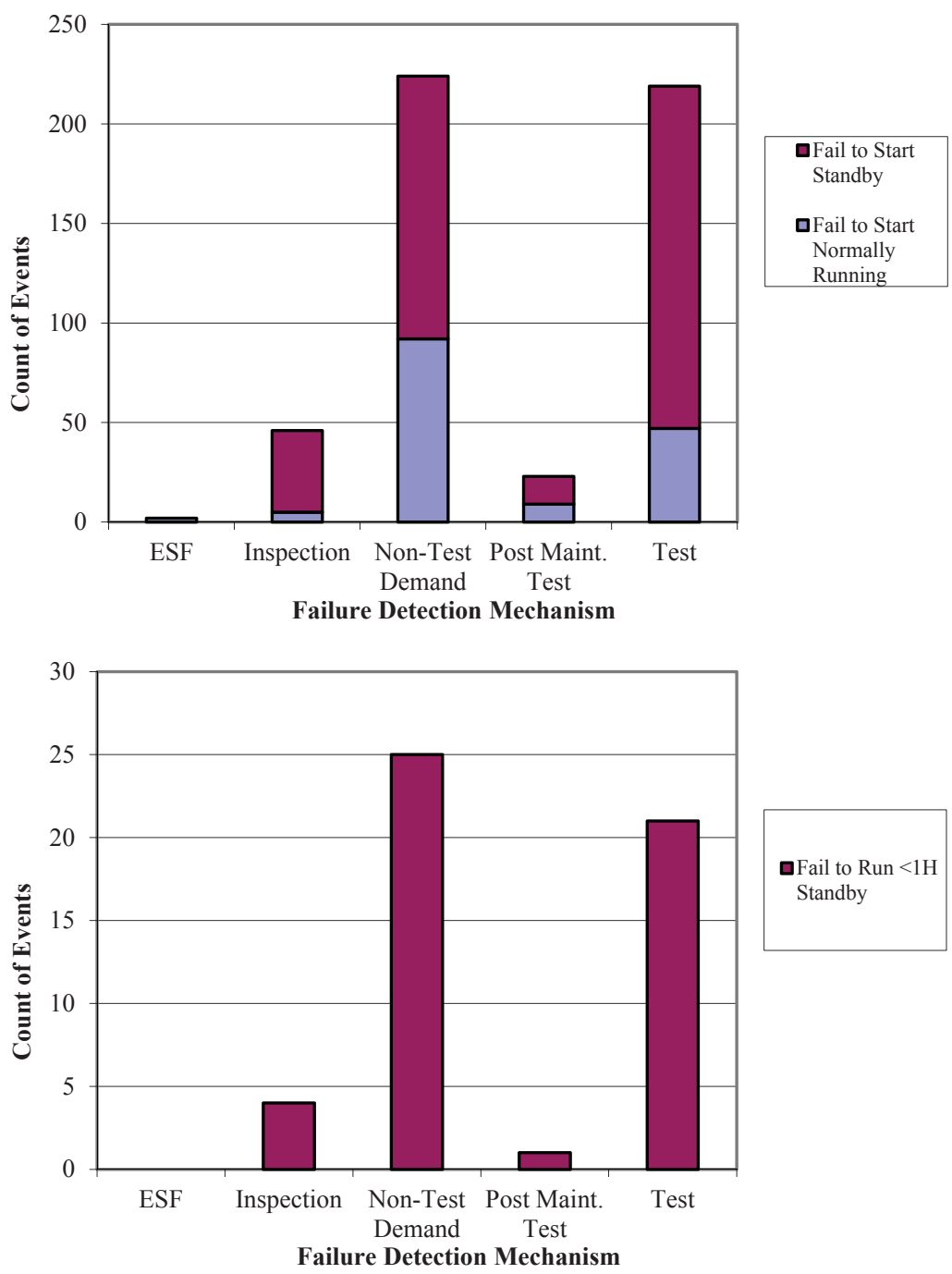

aFail to Run $<1 \mathrm{H}$ Standby

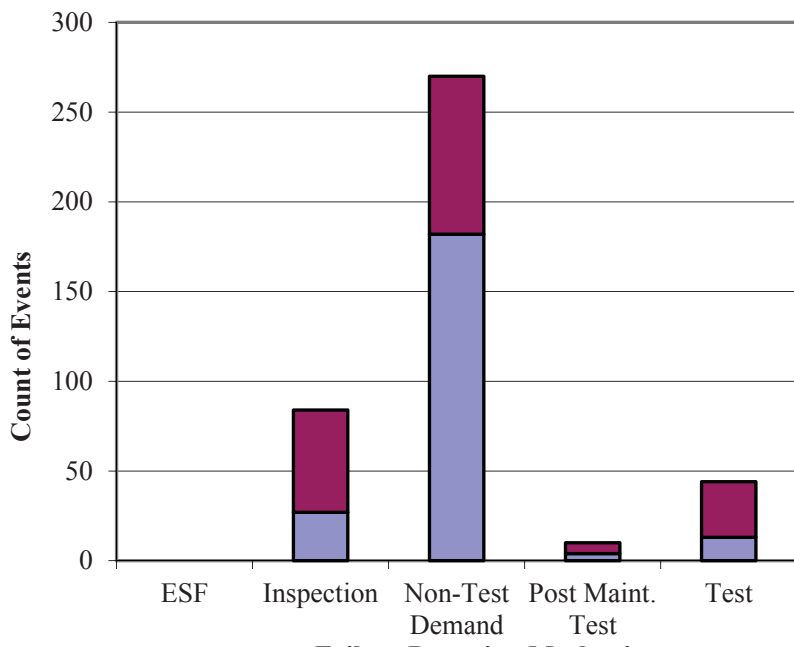

aFail to Run $>1 \mathrm{H}$ Standby

口Fail To Run Normally Running

Figure 21. MDP component failure distribution by period, failure mode, and method of detection. 

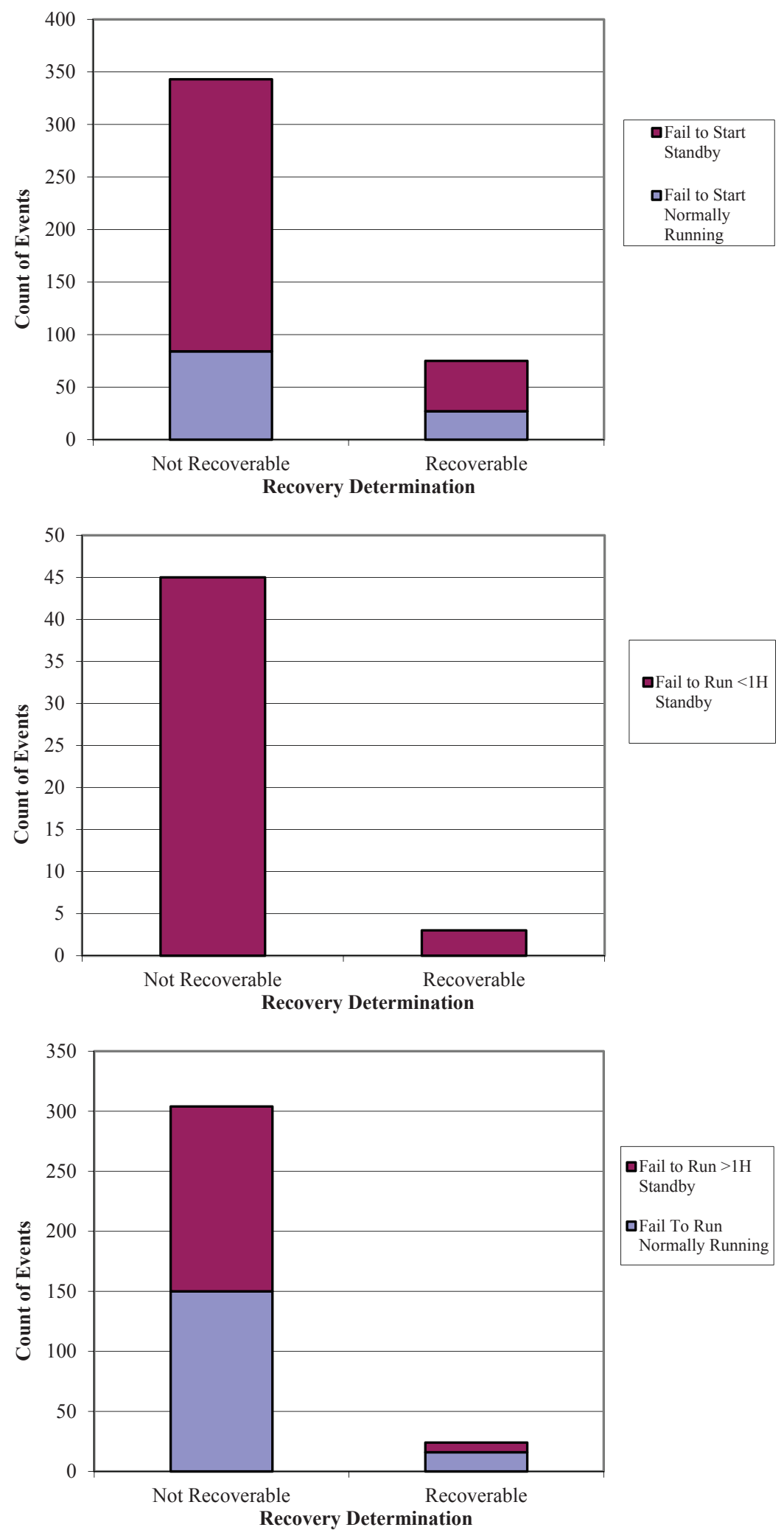

Figure 22. MDP component failure distribution by period, failure mode, and recovery. 


\section{MDP ASSEMBLY DESCRIPTION}

The MDP consists of the pump, motor-driver, and circuit breaker sub-components. All of the pumps are centrifugal, but can be different configurations. The drivers are medium or large ac motors. If the MDP assembly includes a speed increaser, it is treated as a sub-component.

The MDP failure modes include FTS, FTR $<1 \mathrm{H}$, and FTR $>1 \mathrm{H}$. These failure modes were used in NUREG/CR-6928 and are similar to those used in the MSPI Program.

Guidelines for determining whether a component event reported in EPIX is to be included in FTS, FTR $<1 \mathrm{H}$, or FTR $>1 \mathrm{H}$ are similar to those used in the MSPI Program. In general, any circumstance in which the component is not able to meet the performance requirements defined in the PRA is counted. This includes conditions revealed through testing, operational demands, unplanned demands, or discovery. Also, run failures that occur beyond the typical 24-hour mission time in PRAs are included. However, certain events are excluded: slow starting times that do not exceed the PRA success criteria, conditions that are annunciated immediately in the control room without a demand, and run events that are shown to not have caused an actual run failure within 24 hours. Also, events occurring during maintenance or post-maintenance testing that are related to the actual maintenance activities are excluded. All of the MDP events within EPIX were reviewed to ensure that they were binned to the correct failure mode - FTS, FTR $<1 \mathrm{H}$, FTR $>1 \mathrm{H}$, or no failure. However, even given detailed descriptions of failure events, this binning still required some judgment and involves some uncertainty.

Guidelines for counting demands and run hours are similar to those in the MSPI Program. Start and run demands include those resulting from tests, operational demands, and unplanned demands. Demands during maintenance and post-maintenance testing are excluded. Similarly, run hours include those from tests, operational demands, and unplanned demands. 


\section{DATA TABLES}

Table 11. Plot data for standby MDP FTS industry trend. Figure 1

\begin{tabular}{|c|c|c|c|c|c|c|c|c|}
\hline \multirow[b]{2}{*}{$\begin{array}{c}\text { FYI } \\
\text { Source }\end{array}$} & \multirow[b]{2}{*}{ Failures } & \multirow[b]{2}{*}{ Demands } & \multicolumn{3}{|c|}{ Regression Curve Data Points } & \multicolumn{3}{|c|}{ Plot Trend Error Bar Points } \\
\hline & & & Mean & $\begin{array}{c}\text { Lower } \\
(5 \%)\end{array}$ & $\begin{array}{l}\text { Upper } \\
(95 \%) \\
\end{array}$ & $\begin{array}{c}\text { Lower } \\
(5 \%)\end{array}$ & $\begin{array}{l}\text { Upper } \\
(95 \%) \\
\end{array}$ & Mean \\
\hline \multicolumn{2}{|c|}{2010 Update } & & & & & 1.63E-04 & 2.27E-03 & $9.47 E-04$ \\
\hline 1998 & 31 & $23,599.1$ & & & & $9.43 \mathrm{E}-04$ & $1.75 \mathrm{E}-03$ & $1.30 \mathrm{E}-03$ \\
\hline 1999 & 24 & $24,323.9$ & & & & $6.79 \mathrm{E}-04$ & 1.37E-03 & $9.81 \mathrm{E}-04$ \\
\hline 2000 & 27 & $24,467.7$ & & & & 7.76E-04 & $1.50 \mathrm{E}-03$ & 1.09E-03 \\
\hline 2001 & 29 & $24,174.1$ & & & & 8.53E-04 & $1.62 \mathrm{E}-03$ & 1.19E-03 \\
\hline 2002 & 18 & $24,502.6$ & & & & 4.79E-04 & $1.08 \mathrm{E}-03$ & $7.35 \mathrm{E}-04$ \\
\hline 2003 & 39 & $25,941.2$ & 1.14E-03 & 8.71E-04 & $1.49 \mathrm{E}-03$ & $1.12 \mathrm{E}-03$ & $1.94 \mathrm{E}-03$ & $1.49 \mathrm{E}-03$ \\
\hline 2004 & 25 & $27,046.8$ & $1.03 E-03$ & $8.21 \mathrm{E}-04$ & $1.29 \mathrm{E}-03$ & $6.43 \mathrm{E}-04$ & $1.28 \mathrm{E}-03$ & $9.21 \mathrm{E}-04$ \\
\hline 2005 & 19 & $27,101.3$ & $9.29 \mathrm{E}-04$ & $7.68 \mathrm{E}-04$ & $1.12 \mathrm{E}-03$ & 4.63E-04 & $1.03 \mathrm{E}-03$ & 7.03E-04 \\
\hline 2006 & 22 & $26,334.4$ & 8.38E-04 & 7.10E-04 & $9.90 \mathrm{E}-04$ & $5.67 \mathrm{E}-04$ & 1.19E-03 & 8.34E-04 \\
\hline 2007 & 24 & $27,476.5$ & 7.57E-04 & $6.44 \mathrm{E}-04$ & 8.90E-04 & 6.03E-04 & $1.22 \mathrm{E}-03$ & 8.71E-04 \\
\hline 2008 & 16 & $26,779.0$ & $6.83 E-04$ & $5.73 \mathrm{E}-04$ & $8.15 E-04$ & 3.80E-04 & $9.08 \mathrm{E}-04$ & $6.01 \mathrm{E}-04$ \\
\hline 2009 & 17 & $26,328.5$ & $6.17 \mathrm{E}-04$ & 5.02E-04 & $7.58 \mathrm{E}-04$ & 4.16E-04 & $9.67 \mathrm{E}-04$ & $6.49 \mathrm{E}-04$ \\
\hline 2010 & 12 & $26,811.8$ & $5.57 \mathrm{E}-04$ & 4.35E-04 & 7.13E-04 & $2.66 \mathrm{E}-04$ & 7.30E-04 & $4.55 \mathrm{E}-04$ \\
\hline 2011 & 17 & $26,220.8$ & $5.03 E-04$ & $3.75 \mathrm{E}-04$ & $6.74 \mathrm{E}-04$ & $4.18 \mathrm{E}-04$ & $9.71 \mathrm{E}-04$ & $6.51 \mathrm{E}-04$ \\
\hline 2012 & 12 & $25,592.3$ & $4.54 \mathrm{E}-04$ & $3.22 \mathrm{E}-04$ & 6.39E-04 & $2.78 \mathrm{E}-04$ & 7.64E-04 & 4.76E-04 \\
\hline Total & 332 & $386,700.0$ & & & & & & \\
\hline
\end{tabular}

Table 12. Plot data for standby MDP FTR $\leq 1 \mathrm{H}$ industry trend. Figure 2

\begin{tabular}{|c|c|c|c|c|c|c|c|c|}
\hline \multirow[b]{2}{*}{$\begin{array}{c}\text { FYI } \\
\text { Source }\end{array}$} & \multirow[b]{2}{*}{ Failures } & \multirow[b]{2}{*}{ Hours } & \multicolumn{3}{|c|}{ Regression Curve Data Points } & \multicolumn{3}{|c|}{ Plot Trend Error Bar Points } \\
\hline & & & Mean & $\begin{array}{c}\text { Lower } \\
(5 \%)\end{array}$ & $\begin{array}{l}\text { Upper } \\
(95 \%)\end{array}$ & $\begin{array}{c}\text { Lower } \\
(5 \%)\end{array}$ & $\begin{array}{l}\text { Upper } \\
(95 \%)\end{array}$ & Mean \\
\hline \multicolumn{2}{|c|}{2010 Update } & & & & & $1.93 E-05$ & $3.01 \mathrm{E}-04$ & 1.23E-04 \\
\hline 1998 & 6 & $23,599.1$ & & & & $1.05 \mathrm{E}-04$ & 4.47E-04 & 2.33E-04 \\
\hline 1999 & 3 & $24,323.9$ & & & & $3.78 \mathrm{E}-05$ & $2.95 \mathrm{E}-04$ & $1.22 E-04$ \\
\hline 2000 & 4 & $24,467.7$ & & & & $5.77 \mathrm{E}-05$ & $3.41 \mathrm{E}-04$ & $1.56 \mathrm{E}-04$ \\
\hline 2001 & 1 & $24,174.1$ & & & & $6.17 \mathrm{E}-06$ & $1.94 \mathrm{E}-04$ & $5.26 \mathrm{E}-05$ \\
\hline 2002 & 6 & $24,502.6$ & & & & $1.02 \mathrm{E}-04$ & 4.33E-04 & $2.25 E-04$ \\
\hline 2003 & 2 & $25,941.2$ & $1.15 \mathrm{E}-04$ & 7.77E-05 & $1.71 \mathrm{E}-04$ & $1.89 \mathrm{E}-05$ & $2.32 \mathrm{E}-04$ & $8.25 E-05$ \\
\hline 2004 & 3 & $27,046.8$ & $1.14 \mathrm{E}-04$ & 8.17E-05 & $1.59 \mathrm{E}-04$ & $3.45 \mathrm{E}-05$ & 2.69E-04 & $1.11 \mathrm{E}-04$ \\
\hline 2005 & 5 & $27,101.3$ & $1.13 \mathrm{E}-04$ & $8.53 E-05$ & $1.49 \mathrm{E}-04$ & 7.27E-05 & $3.55 \mathrm{E}-04$ & $1.75 \mathrm{E}-04$ \\
\hline 2006 & 4 & $26,334.4$ & $1.12 \mathrm{E}-04$ & $8.79 E-05$ & $1.42 \mathrm{E}-04$ & $5.42 \mathrm{E}-05$ & $3.21 \mathrm{E}-04$ & 1.47E-04 \\
\hline 2007 & 3 & $27,476.5$ & 1.10E-04 & $8.90 E-05$ & 1.37E-04 & $3.40 \mathrm{E}-05$ & $2.66 \mathrm{E}-04$ & $1.10 \mathrm{E}-04$ \\
\hline 2008 & 2 & $26,779.0$ & $1.09 \mathrm{E}-04$ & $8.79 E-05$ & 1.36E-04 & $1.84 \mathrm{E}-05$ & $2.26 \mathrm{E}-04$ & $8.03 E-05$ \\
\hline 2009 & 3 & $26,328.5$ & $1.08 \mathrm{E}-04$ & $8.48 \mathrm{E}-05$ & $1.38 \mathrm{E}-04$ & $3.53 \mathrm{E}-05$ & $2.76 \mathrm{E}-04$ & $1.14 \mathrm{E}-04$ \\
\hline 2010 & 2 & $26,811.8$ & $1.07 E-04$ & 8.03E-05 & $1.43 \mathrm{E}-04$ & $1.84 \mathrm{E}-05$ & $2.26 \mathrm{E}-04$ & $8.02 E-05$ \\
\hline 2011 & 3 & $26,220.8$ & $1.06 \mathrm{E}-04$ & $7.53 \mathrm{E}-05$ & $1.49 \mathrm{E}-04$ & $3.54 \mathrm{E}-05$ & 2.77E-04 & $1.14 \mathrm{E}-04$ \\
\hline 2012 & 3 & $25,592.3$ & 1.05E-04 & 7.01E-05 & $1.57 \mathrm{E}-04$ & $3.62 E-05$ & $2.82 \mathrm{E}-04$ & 1.17E-04 \\
\hline Total & 50 & $386,700.0$ & & & & & & \\
\hline
\end{tabular}


Table 13. Plot data for standby MDP FTR $>1 \mathrm{H}$ industry trend. Figure 3

\begin{tabular}{|c|c|c|c|c|c|c|c|c|}
\hline \multirow[b]{2}{*}{$\begin{array}{c}\text { FYI } \\
\text { Source }\end{array}$} & \multirow[b]{2}{*}{ Failures } & \multirow[b]{2}{*}{$\begin{array}{l}\text { Run Time } \\
\text { (hr) }\end{array}$} & \multicolumn{3}{|c|}{ Regression Curve Data Points } & \multicolumn{3}{|c|}{ Plot Trend Error Bar Points } \\
\hline & & & Mean & $\begin{array}{c}\text { Lower } \\
(5 \%)\end{array}$ & $\begin{array}{l}\text { Upper } \\
(95 \%) \\
\end{array}$ & $\begin{array}{c}\text { Lower } \\
\mathbf{( 5 \% )}\end{array}$ & $\begin{array}{l}\text { Upper } \\
(95 \%)\end{array}$ & Mean \\
\hline \multicolumn{2}{|c|}{2010 Update } & & & & & 2.64E-07 & $3.41 \mathrm{E}-05$ & $1.04 \mathrm{E}-05$ \\
\hline 1998 & 8 & $933,236.0$ & & & & $4.42 \mathrm{E}-06$ & $1.54 \mathrm{E}-05$ & $8.66 \mathrm{E}-06$ \\
\hline 1999 & 6 & $916,422.8$ & & & & $3.05 E-06$ & $1.30 \mathrm{E}-05$ & $6.74 \mathrm{E}-06$ \\
\hline 2000 & 11 & $874,515.3$ & & & & $7.10 \mathrm{E}-06$ & $2.04 \mathrm{E}-05$ & $1.25 \mathrm{E}-05$ \\
\hline 2001 & 12 & $885,303.0$ & & & & $7.83 E-06$ & $2.15 \mathrm{E}-05$ & $1.34 \mathrm{E}-05$ \\
\hline 2002 & 18 & $950,069.4$ & & & & $1.21 \mathrm{E}-05$ & 2.73E-05 & 1.85E-05 \\
\hline 2003 & 16 & $1,066,970.8$ & $1.11 \mathrm{E}-05$ & $6.04 \mathrm{E}-06$ & $2.03 E-05$ & $9.36 \mathrm{E}-06$ & $2.23 \mathrm{E}-05$ & $1.48 E-05$ \\
\hline 2004 & 14 & $1,142,885.5$ & $1.08 \mathrm{E}-05$ & $6.45 \mathrm{E}-06$ & $1.80 \mathrm{E}-05$ & $7.43 E-06$ & $1.89 \mathrm{E}-05$ & $1.22 \mathrm{E}-05$ \\
\hline 2005 & 12 & $1,148,158.1$ & $1.05 \mathrm{E}-05$ & $6.81 \mathrm{E}-06$ & $1.61 \mathrm{E}-05$ & $6.11 \mathrm{E}-06$ & $1.68 \mathrm{E}-05$ & $1.05 E-05$ \\
\hline 2006 & 4 & $1,147,175.5$ & $1.02 \mathrm{E}-05$ & 7.06E-06 & 1.47E-05 & $1.39 E-06$ & $8.23 E-06$ & $3.77 E-06$ \\
\hline 2007 & 15 & $1,161,848.5$ & $9.92 \mathrm{E}-06$ & $7.10 \mathrm{E}-06$ & $1.39 \mathrm{E}-05$ & 7.97E-06 & $1.96 \mathrm{E}-05$ & $1.28 \mathrm{E}-05$ \\
\hline 2008 & 17 & $1,181,871.9$ & $9.65 \mathrm{E}-06$ & $6.86 \mathrm{E}-06$ & 1.36E-05 & $9.13 \mathrm{E}-06$ & $2.12 \mathrm{E}-05$ & $1.42 \mathrm{E}-05$ \\
\hline 2009 & 9 & $1,162,200.4$ & $9.39 \mathrm{E}-06$ & $6.40 \mathrm{E}-06$ & $1.38 \mathrm{E}-05$ & $4.18 \mathrm{E}-06$ & $1.35 \mathrm{E}-05$ & $7.85 E-06$ \\
\hline 2010 & 10 & $1,179,233.1$ & $9.14 \mathrm{E}-06$ & $5.81 \mathrm{E}-06$ & 1.44E-05 & $4.72 E-06$ & 1.43E-05 & $8.56 \mathrm{E}-06$ \\
\hline 2011 & 13 & $1,177,932.0$ & 8.89E-06 & $5.18 \mathrm{E}-06$ & $1.52 \mathrm{E}-05$ & $6.59 \mathrm{E}-06$ & $1.74 \mathrm{E}-05$ & $1.10 \mathrm{E}-05$ \\
\hline 2012 & 10 & $1,190,070.3$ & $8.65 E-06$ & $4.58 \mathrm{E}-06$ & $1.63 \mathrm{E}-05$ & $4.68 \mathrm{E}-06$ & $1.42 \mathrm{E}-05$ & $8.48 E-06$ \\
\hline Total & 175 & $16,117,892.3$ & & & & & & \\
\hline
\end{tabular}

Table 14. Plot data for normally running MDP FTS industry trend. Figure 4

\begin{tabular}{|c|c|c|c|c|c|c|c|c|}
\hline \multirow[b]{2}{*}{$\begin{array}{c}\text { FYI } \\
\text { Source }\end{array}$} & \multirow[b]{2}{*}{ Failures } & \multirow[b]{2}{*}{ Demands } & \multicolumn{3}{|c|}{ Regression Curve Data Points } & \multicolumn{3}{|c|}{ Plot Trend Error Bar Points } \\
\hline & & & Mean & $\begin{array}{l}\text { Lower } \\
(5 \%)\end{array}$ & $\begin{array}{l}\text { Upper } \\
(95 \%)\end{array}$ & $\begin{array}{c}\text { Lower } \\
(5 \%)\end{array}$ & $\begin{array}{l}\text { Upper } \\
(95 \%)\end{array}$ & Mean \\
\hline \multicolumn{2}{|c|}{2010 Update } & & & & & $4.01 \mathrm{E}-04$ & $2.79 \mathrm{E}-03$ & 1.36E-03 \\
\hline 1998 & 11 & $7,228.8$ & & & & 8.50E-04 & $2.44 \mathrm{E}-03$ & 1.49E-03 \\
\hline 1999 & 13 & $7,346.4$ & & & & $1.03 E-03$ & $2.72 \mathrm{E}-03$ & 1.73E-03 \\
\hline 2000 & 5 & $7,450.2$ & & & & $2.89 \mathrm{E}-04$ & $1.41 \mathrm{E}-03$ & $6.94 \mathrm{E}-04$ \\
\hline 2001 & 9 & $7,415.0$ & & & & $6.41 \mathrm{E}-04$ & $2.07 \mathrm{E}-03$ & $1.20 \mathrm{E}-03$ \\
\hline 2002 & 12 & $7,675.5$ & & & & 8.97E-04 & $2.46 \mathrm{E}-03$ & $1.53 \mathrm{E}-03$ \\
\hline 2003 & 14 & $8,270.2$ & $1.31 \mathrm{E}-03$ & $9.55 E-04$ & $1.79 \mathrm{E}-03$ & $1.01 \mathrm{E}-03$ & $2.57 \mathrm{E}-03$ & $1.66 \mathrm{E}-03$ \\
\hline 2004 & 10 & $8,438.3$ & $1.23 \mathrm{E}-03$ & $9.48 \mathrm{E}-04$ & $1.61 \mathrm{E}-03$ & $6.50 E-04$ & 1.97E-03 & 1.18E-03 \\
\hline 2005 & 6 & $8,507.7$ & 1.17E-03 & $9.35 \mathrm{E}-04$ & $1.46 \mathrm{E}-03$ & $3.28 \mathrm{E}-04$ & 1.39E-03 & $7.24 \mathrm{E}-04$ \\
\hline 2006 & 12 & $8,588.3$ & 1.10E-03 & $9.12 \mathrm{E}-04$ & $1.34 \mathrm{E}-03$ & 8.06E-04 & $2.21 \mathrm{E}-03$ & $1.38 \mathrm{E}-03$ \\
\hline 2007 & 9 & $8,744.7$ & $1.04 \mathrm{E}-03$ & 8.73E-04 & $1.25 \mathrm{E}-03$ & $5.49 \mathrm{E}-04$ & 1.77E-03 & $1.03 E-03$ \\
\hline 2008 & 9 & $8,700.0$ & $9.87 \mathrm{E}-04$ & 8.19E-04 & 1.19E-03 & $5.51 \mathrm{E}-04$ & $1.78 \mathrm{E}-03$ & $1.04 \mathrm{E}-03$ \\
\hline 2009 & 8 & $8,568.4$ & $9.33 \mathrm{E}-04$ & 7.53E-04 & 1.16E-03 & $4.80 \mathrm{E}-04$ & 1.67E-03 & $9.40 \mathrm{E}-04$ \\
\hline 2010 & 8 & $8,553.7$ & 8.82E-04 & $6.84 \mathrm{E}-04$ & $1.14 \mathrm{E}-03$ & $4.80 E-04$ & 1.67E-03 & $9.41 \mathrm{E}-04$ \\
\hline 2011 & 6 & $8,348.4$ & 8.34E-04 & 6.17E-04 & $1.13 \mathrm{E}-03$ & $3.34 \mathrm{E}-04$ & $1.42 \mathrm{E}-03$ & 7.37E-04 \\
\hline 2012 & 7 & $8,249.6$ & $7.89 \mathrm{E}-04$ & $5.53 \mathrm{E}-04$ & $1.12 \mathrm{E}-03$ & 4.16E-04 & $1.58 \mathrm{E}-03$ & 8.60E-04 \\
\hline Total & 139 & $122,085.2$ & & & & & & \\
\hline
\end{tabular}


Table 15. Plot data for normally running MDP FTR industry trend. Figure 5

\begin{tabular}{|c|c|c|c|c|c|c|c|c|}
\hline \multirow{2}{*}{$\begin{array}{c}\text { FYI } \\
\text { Sourc } \\
\mathbf{e}\end{array}$} & \multirow[b]{2}{*}{ Failures } & \multirow[b]{2}{*}{$\begin{array}{l}\text { Run Time } \\
\text { (hr) }\end{array}$} & \multicolumn{3}{|c|}{ Regression Curve Data Points } & \multicolumn{3}{|c|}{ Plot Trend Error Bar Points } \\
\hline & & & Mean & $\begin{array}{c}\text { Lower } \\
(5 \%)\end{array}$ & $\begin{array}{l}\text { Upper } \\
(95 \%)\end{array}$ & $\begin{array}{l}\text { Lower } \\
(5 \%)\end{array}$ & $\begin{array}{l}\text { Upper } \\
(95 \%)\end{array}$ & Mean \\
\hline \multicolumn{2}{|c|}{2010 Update } & & & & & 7.37E-07 & $8.02 \mathrm{E}-06$ & $3.53 E-06$ \\
\hline 1998 & 22 & $2,832,021.8$ & & & & $5.15 \mathrm{E}-06$ & $1.08 \mathrm{E}-05$ & 7.57E-06 \\
\hline 1999 & 16 & $2,915,624.6$ & & & & $3.41 \mathrm{E}-06$ & $8.15 E-06$ & $5.40 \mathrm{E}-06$ \\
\hline 2000 & 24 & $2,940,278.6$ & & & & $5.51 \mathrm{E}-06$ & $1.11 \mathrm{E}-05$ & 7.95E-06 \\
\hline 2001 & 16 & $2,946,540.5$ & & & & $3.38 \mathrm{E}-06$ & 8.06E-06 & 5.34E-06 \\
\hline 2002 & 14 & $2,991,227.0$ & & & & $2.83 E-06$ & $7.18 \mathrm{E}-06$ & 4.63E-06 \\
\hline 2003 & 10 & $3,097,421.0$ & $2.97 \mathrm{E}-06$ & $1.64 \mathrm{E}-06$ & $5.39 \mathrm{E}-06$ & $1.79 \mathrm{E}-06$ & $5.43 E-06$ & $3.24 \mathrm{E}-06$ \\
\hline 2004 & 8 & $3,166,854.5$ & $3.04 \mathrm{E}-06$ & 1.83E-06 & $5.04 \mathrm{E}-06$ & $1.31 \mathrm{E}-06$ & $4.56 \mathrm{E}-06$ & 2.57E-06 \\
\hline 2005 & 6 & $3,148,465.2$ & $3.10 \mathrm{E}-06$ & 2.03E-06 & $4.75 \mathrm{E}-06$ & 8.96E-07 & $3.80 \mathrm{E}-06$ & $1.98 \mathrm{E}-06$ \\
\hline 2006 & 10 & $3,137,029.5$ & $3.17 E-06$ & $2.21 \mathrm{E}-06$ & $4.55 \mathrm{E}-06$ & 1.77E-06 & 5.36E-06 & $3.20 E-06$ \\
\hline 2007 & 11 & $3,138,516.0$ & $3.24 \mathrm{E}-06$ & $2.36 \mathrm{E}-06$ & 4.47E-06 & $2.00 \mathrm{E}-06$ & $5.74 \mathrm{E}-06$ & $3.51 \mathrm{E}-06$ \\
\hline 2008 & 15 & $3,164,584.7$ & $3.32 \mathrm{E}-06$ & $2.42 \mathrm{E}-06$ & 4.54E-06 & $2.92 \mathrm{E}-06$ & 7.17E-06 & 4.69E-06 \\
\hline 2009 & 25 & $3,154,559.0$ & $3.39 \mathrm{E}-06$ & $2.40 \mathrm{E}-06$ & $4.78 \mathrm{E}-06$ & $5.40 \mathrm{E}-06$ & $1.08 \mathrm{E}-05$ & $7.74 \mathrm{E}-06$ \\
\hline 2010 & 8 & $3,152,939.9$ & $3.47 E-06$ & $2.32 \mathrm{E}-06$ & $5.18 \mathrm{E}-06$ & $1.32 \mathrm{E}-06$ & $4.58 \mathrm{E}-06$ & $2.58 E-06$ \\
\hline 2011 & 9 & $3,150,629.8$ & $3.54 \mathrm{E}-06$ & $2.20 \mathrm{E}-06$ & $5.72 \mathrm{E}-06$ & $1.54 \mathrm{E}-06$ & $4.96 \mathrm{E}-06$ & $2.89 E-06$ \\
\hline 2012 & 9 & $3,150,271.5$ & $3.62 E-06$ & 2.06E-06 & $6.37 E-06$ & $1.54 \mathrm{E}-06$ & 4.96E-06 & $2.89 E-06$ \\
\hline Total & 203 & $46,086,963.8$ & & & & & & \\
\hline
\end{tabular}

Table 16. Plot data for all standby MDP unavailability trend. Figure 6

\begin{tabular}{ccccccccc}
\hline & & & \multicolumn{2}{c}{ Regression Curve Data Points } & \multicolumn{2}{c}{ Plot Trend Error Bar Points } \\
\cline { 6 - 9 } FY & UA Hours & Hours & Mean & $\begin{array}{c}\text { Lower } \\
\mathbf{( 5 \% )}\end{array}$ & $\begin{array}{c}\text { Upper } \\
\mathbf{( 9 5 \% )}\end{array}$ & $\begin{array}{c}\text { Lower } \\
\mathbf{( 5 \% )}\end{array}$ & $\begin{array}{c}\text { Upper } \\
\mathbf{( 9 5 \% )}\end{array}$ & Mean \\
\hline \multicolumn{2}{c}{2010 Update } & & & & & $3.59 \mathrm{E}-04$ & $2.10 \mathrm{E}-02$ & $7.00 \mathrm{E}-03$ \\
\hline 1998 & $10,607.8$ & $1,713,843.7$ & & & & $9.44 \mathrm{E}-05$ & $2.16 \mathrm{E}-02$ & $6.28 \mathrm{E}-03$ \\
\hline 1999 & $12,906.2$ & $2,452,645.5$ & & & & $6.69 \mathrm{E}-04$ & $1.31 \mathrm{E}-02$ & $5.16 \mathrm{E}-03$ \\
\hline 2000 & $13,130.0$ & $2,537,111.3$ & & & & $6.63 \mathrm{E}-04$ & $1.22 \mathrm{E}-02$ & $4.86 \mathrm{E}-03$ \\
\hline 2001 & $12,728.1$ & $2,542,239.9$ & & & & $5.77 \mathrm{E}-04$ & $1.28 \mathrm{E}-02$ & $4.94 \mathrm{E}-03$ \\
\hline 2002 & $18,010.2$ & $3,819,764.7$ & & & & $5.55 \mathrm{E}-04$ & $1.26 \mathrm{E}-02$ & $4.83 \mathrm{E}-03$ \\
\hline 2003 & $21,358.6$ & $4,290,105.7$ & $4.35 \mathrm{E}-03$ & $3.89 \mathrm{E}-03$ & $4.82 \mathrm{E}-03$ & $4.63 \mathrm{E}-04$ & $1.32 \mathrm{E}-02$ & $4.88 \mathrm{E}-03$ \\
\hline 2004 & $19,662.9$ & $4,473,656.1$ & $4.32 \mathrm{E}-03$ & $3.93 \mathrm{E}-03$ & $4.72 \mathrm{E}-03$ & $6.05 \mathrm{E}-04$ & $1.09 \mathrm{E}-02$ & $4.34 \mathrm{E}-03$ \\
\hline 2005 & $19,004.5$ & $4,413,226.1$ & $4.30 \mathrm{E}-03$ & $3.96 \mathrm{E}-03$ & $4.63 \mathrm{E}-03$ & $2.48 \mathrm{E}-04$ & $1.29 \mathrm{E}-02$ & $4.39 \mathrm{E}-03$ \\
\hline 2006 & $17,693.4$ & $4,488,097.5$ & $4.27 \mathrm{E}-03$ & $3.98 \mathrm{E}-03$ & $4.55 \mathrm{E}-03$ & $3.71 \mathrm{E}-04$ & $1.02 \mathrm{E}-02$ & $3.80 \mathrm{E}-03$ \\
\hline 2007 & $17,015.5$ & $4,464,312.7$ & $4.24 \mathrm{E}-03$ & $3.98 \mathrm{E}-03$ & $4.49 \mathrm{E}-03$ & $3.18 \mathrm{E}-04$ & $1.05 \mathrm{E}-02$ & $3.80 \mathrm{E}-03$ \\
\hline 2008 & $18,367.5$ & $4,459,856.1$ & $4.21 \mathrm{E}-03$ & $3.95 \mathrm{E}-03$ & $4.46 \mathrm{E}-03$ & $4.46 \mathrm{E}-04$ & $1.08 \mathrm{E}-02$ & $4.09 \mathrm{E}-03$ \\
\hline 2009 & $18,776.7$ & $4,474,114.8$ & $4.18 \mathrm{E}-03$ & $3.89 \mathrm{E}-03$ & $4.46 \mathrm{E}-03$ & $3.81 \mathrm{E}-04$ & $1.09 \mathrm{E}-02$ & $4.03 \mathrm{E}-03$ \\
\hline 2010 & $18,862.3$ & $4,393,087.5$ & $4.15 \mathrm{E}-03$ & $3.81 \mathrm{E}-03$ & $4.48 \mathrm{E}-03$ & $4.53 \mathrm{E}-04$ & $1.14 \mathrm{E}-02$ & $4.31 \mathrm{E}-03$ \\
\hline 2011 & $18,260.9$ & $4,337,722.4$ & $4.12 \mathrm{E}-03$ & $3.72 \mathrm{E}-03$ & $4.51 \mathrm{E}-03$ & $5.19 \mathrm{E}-04$ & $1.08 \mathrm{E}-02$ & $4.18 \mathrm{E}-03$ \\
\hline 2012 & $19,227.5$ & $4,251,724.3$ & $4.09 \mathrm{E}-03$ & $3.62 \mathrm{E}-03$ & $4.56 \mathrm{E}-03$ & $3.25 \mathrm{E}-04$ & $1.24 \mathrm{E}-02$ & $4.39 \mathrm{E}-03$ \\
\hline
\end{tabular}


Table 17. Plot data for Standby MDP unreliability trend. Figure 7

\begin{tabular}{ccccccc}
\hline & \multicolumn{2}{c}{ Regression Curve Data Points } & \multicolumn{3}{c}{ Plot Trend Error Bar Points } \\
\cline { 2 - 7 } FY & Mean & $\begin{array}{c}\text { Lower } \\
\mathbf{( 5 \% )}\end{array}$ & Mean & $\begin{array}{c}\text { Lower } \\
\mathbf{( 5 \% )}\end{array}$ & Mean & Mean \\
\hline 1998 & & & & $1.68 \mathrm{E}-03$ & $2.31 \mathrm{E}-02$ & $7.87 \mathrm{E}-03$ \\
1999 & & & & $1.82 \mathrm{E}-03$ & $1.43 \mathrm{E}-02$ & $6.31 \mathrm{E}-03$ \\
\hline 2000 & & & & $2.00 \mathrm{E}-03$ & $1.35 \mathrm{E}-02$ & $6.19 \mathrm{E}-03$ \\
2001 & & & & $1.91 \mathrm{E}-03$ & $1.42 \mathrm{E}-02$ & $6.27 \mathrm{E}-03$ \\
\hline 2002 & & & & $1.64 \mathrm{E}-03$ & $1.37 \mathrm{E}-02$ & $5.92 \mathrm{E}-03$ \\
2003 & $5.68 \mathrm{E}-03$ & $3.49 \mathrm{E}-03$ & $9.10 \mathrm{E}-03$ & $2.14 \mathrm{E}-03$ & $1.48 \mathrm{E}-02$ & $6.55 \mathrm{E}-03$ \\
\hline 2004 & $5.57 \mathrm{E}-03$ & $3.72 \mathrm{E}-03$ & $8.21 \mathrm{E}-03$ & $1.71 \mathrm{E}-03$ & $1.20 \mathrm{E}-02$ & $5.45 \mathrm{E}-03$ \\
\hline 2005 & $5.46 \mathrm{E}-03$ & $3.92 \mathrm{E}-03$ & $7.48 \mathrm{E}-03$ & $1.19 \mathrm{E}-03$ & $1.39 \mathrm{E}-02$ & $5.34 \mathrm{E}-03$ \\
\hline 2006 & $5.34 \mathrm{E}-03$ & $4.05 \mathrm{E}-03$ & $6.96 \mathrm{E}-03$ & $1.37 \mathrm{E}-03$ & $1.12 \mathrm{E}-02$ & $4.81 \mathrm{E}-03$ \\
\hline 2007 & $5.23 \mathrm{E}-03$ & $4.05 \mathrm{E}-03$ & $6.68 \mathrm{E}-03$ & $1.39 \mathrm{E}-03$ & $1.16 \mathrm{E}-02$ & $4.87 \mathrm{E}-03$ \\
\hline 2008 & $5.12 \mathrm{E}-03$ & $3.89 \mathrm{E}-03$ & $6.68 \mathrm{E}-03$ & $1.22 \mathrm{E}-03$ & $1.15 \mathrm{E}-02$ & $4.87 \mathrm{E}-03$ \\
2009 & $5.00 \mathrm{E}-03$ & $3.62 \mathrm{E}-03$ & $6.90 \mathrm{E}-03$ & $1.19 \mathrm{E}-03$ & $1.17 \mathrm{E}-02$ & $4.86 \mathrm{E}-03$ \\
\hline 2010 & $4.89 \mathrm{E}-03$ & $3.29 \mathrm{E}-03$ & $7.27 \mathrm{E}-03$ & $1.05 \mathrm{E}-03$ & $1.20 \mathrm{E}-02$ & $4.90 \mathrm{E}-03$ \\
\hline 2011 & $4.78 \mathrm{E}-03$ & $2.97 \mathrm{E}-03$ & $7.75 \mathrm{E}-03$ & $1.35 \mathrm{E}-03$ & $1.16 \mathrm{E}-02$ & $5.03 \mathrm{E}-03$ \\
\hline 2012 & $4.66 \mathrm{E}-03$ & $2.66 \mathrm{E}-03$ & $8.30 \mathrm{E}-03$ & $9.76 \mathrm{E}-04$ & $1.30 \mathrm{E}-02$ & $5.04 \mathrm{E}-03$ \\
\hline
\end{tabular}

Table 18. Plot data for NR MDP unreliability trend. Figure 8

\begin{tabular}{ccccccc}
\hline & \multicolumn{2}{c}{ Regression Curve Data Points } & \multicolumn{3}{c}{ Plot Trend Error Bar Points } \\
\cline { 2 - 7 } FY & Mean & $\begin{array}{c}\text { Lower } \\
\mathbf{( 5 \% )}\end{array}$ & Mean & $\begin{array}{c}\text { Lower } \\
\mathbf{( 5 \% )}\end{array}$ & Mean & Mean \\
\hline 1998 & & & & $1.64 \mathrm{E}-03$ & $2.31 \mathrm{E}-02$ & $7.82 \mathrm{E}-03$ \\
1999 & & & & $2.42 \mathrm{E}-03$ & $1.49 \mathrm{E}-02$ & $6.92 \mathrm{E}-03$ \\
\hline 2000 & & & & $1.41 \mathrm{E}-03$ & $1.30 \mathrm{E}-02$ & $5.61 \mathrm{E}-03$ \\
2001 & & & & $1.82 \mathrm{E}-03$ & $1.41 \mathrm{E}-02$ & $6.17 \mathrm{E}-03$ \\
\hline 2002 & & & & $2.13 \mathrm{E}-03$ & $1.42 \mathrm{E}-02$ & $6.39 \mathrm{E}-03$ \\
\hline 2003 & $5.71 \mathrm{E}-03$ & $5.57 \mathrm{E}-03$ & $5.78 \mathrm{E}-03$ & $2.13 \mathrm{E}-03$ & $1.49 \mathrm{E}-02$ & $6.56 \mathrm{E}-03$ \\
\hline 2004 & $5.62 \mathrm{E}-03$ & $5.50 \mathrm{E}-03$ & $5.67 \mathrm{E}-03$ & $1.80 \mathrm{E}-03$ & $1.20 \mathrm{E}-02$ & $5.53 \mathrm{E}-03$ \\
\hline 2005 & $5.52 \mathrm{E}-03$ & $5.42 \mathrm{E}-03$ & $5.57 \mathrm{E}-03$ & $9.89 \mathrm{E}-04$ & $1.37 \mathrm{E}-02$ & $5.13 \mathrm{E}-03$ \\
\hline 2006 & $5.43 \mathrm{E}-03$ & $5.35 \mathrm{E}-03$ & $5.46 \mathrm{E}-03$ & $1.78 \mathrm{E}-03$ & $1.16 \mathrm{E}-02$ & $5.20 \mathrm{E}-03$ \\
\hline 2007 & $5.34 \mathrm{E}-03$ & $5.27 \mathrm{E}-03$ & $5.37 \mathrm{E}-03$ & $1.36 \mathrm{E}-03$ & $1.15 \mathrm{E}-02$ & $4.85 \mathrm{E}-03$ \\
\hline 2008 & $5.25 \mathrm{E}-03$ & $5.18 \mathrm{E}-03$ & $5.29 \mathrm{E}-03$ & $1.51 \mathrm{E}-03$ & $1.19 \mathrm{E}-02$ & $5.16 \mathrm{E}-03$ \\
\hline 2009 & $5.15 \mathrm{E}-03$ & $5.08 \mathrm{E}-03$ & $5.22 \mathrm{E}-03$ & $1.37 \mathrm{E}-03$ & $1.19 \mathrm{E}-02$ & $5.02 \mathrm{E}-03$ \\
\hline 2010 & $5.06 \mathrm{E}-03$ & $4.99 \mathrm{E}-03$ & $5.15 \mathrm{E}-03$ & $1.41 \mathrm{E}-03$ & $1.23 \mathrm{E}-02$ & $5.27 \mathrm{E}-03$ \\
\hline 2011 & $4.97 \mathrm{E}-03$ & $4.89 \mathrm{E}-03$ & $5.08 \mathrm{E}-03$ & $1.27 \mathrm{E}-03$ & $1.15 \mathrm{E}-02$ & $4.94 \mathrm{E}-03$ \\
\hline 2012 & $4.88 \mathrm{E}-03$ & $4.79 \mathrm{E}-03$ & $5.02 \mathrm{E}-03$ & $1.20 \mathrm{E}-03$ & $1.32 \mathrm{E}-02$ & $5.27 \mathrm{E}-03$ \\
\hline
\end{tabular}


Table 19. Plot data for standby MDP start demands trend. Figure 9

\begin{tabular}{|c|c|c|c|c|c|c|c|c|}
\hline \multirow[b]{2}{*}{ FY } & \multirow[b]{2}{*}{$\begin{array}{c}\text { Deman } \\
\text { ds }\end{array}$} & \multirow[b]{2}{*}{$\begin{array}{c}\text { Reactor } \\
\text { Years }\end{array}$} & \multicolumn{3}{|c|}{ Regression Curve Data Points } & \multicolumn{3}{|c|}{ Plot Trend Error Bar Points } \\
\hline & & & Mean & $\begin{array}{c}\text { Lower } \\
(5 \%)\end{array}$ & $\begin{array}{l}\text { Upper } \\
(95 \%) \\
\end{array}$ & $\begin{array}{c}\text { Lower } \\
(5 \%)\end{array}$ & $\begin{array}{l}\text { Upper } \\
(95 \%) \\
\end{array}$ & Mean \\
\hline 1998 & 23,599 & 103.0 & & & & $2.27 E+02$ & $2.32 E+02$ & $2.29 E+02$ \\
\hline 1999 & 24,324 & 103.0 & & & & $2.34 \mathrm{E}+02$ & $2.39 E+02$ & $2.36 \mathrm{E}+02$ \\
\hline 2000 & 24,468 & 103.3 & & & & $2.34 \mathrm{E}+02$ & $2.39 E+02$ & $2.37 E+02$ \\
\hline 2001 & 24,174 & 103.0 & & & & $2.32 \mathrm{E}+02$ & $2.37 E+02$ & $2.35 E+02$ \\
\hline 2002 & 24,503 & 103.0 & & & & $2.35 \mathrm{E}+02$ & $2.40 \mathrm{E}+02$ & $2.38 E+02$ \\
\hline 2003 & 25,941 & 103.0 & $2.61 \mathrm{E}+02$ & $2.53 E+02$ & $2.69 E+02$ & $2.49 \mathrm{E}+02$ & $2.54 \mathrm{E}+02$ & $2.52 E+02$ \\
\hline 2004 & 27,047 & 103.3 & $2.60 \mathrm{E}+02$ & $2.53 E+02$ & $2.67 E+02$ & $2.59 \mathrm{E}+02$ & $2.65 E+02$ & $2.62 E+02$ \\
\hline 2005 & 27,101 & 103.0 & $2.59 \mathrm{E}+02$ & $2.53 E+02$ & $2.65 E+02$ & $2.60 \mathrm{E}+02$ & $2.66 \mathrm{E}+02$ & $2.63 E+02$ \\
\hline 2006 & 26,334 & 103.0 & $2.58 \mathrm{E}+02$ & $2.53 E+02$ & $2.63 E+02$ & $2.53 \mathrm{E}+02$ & $2.58 \mathrm{E}+02$ & $2.56 \mathrm{E}+02$ \\
\hline 2007 & 27,476 & 103.4 & $2.57 E+02$ & $2.52 E+02$ & $2.61 \mathrm{E}+02$ & $2.63 \mathrm{E}+02$ & $2.68 E+02$ & $2.66 \mathrm{E}+02$ \\
\hline 2008 & 26,779 & 104.3 & $2.56 \mathrm{E}+02$ & $2.51 \mathrm{E}+02$ & $2.60 E+02$ & $2.54 \mathrm{E}+02$ & $2.59 E+02$ & $2.57 E+02$ \\
\hline 2009 & 26,329 & 104.0 & $2.55 \mathrm{E}+02$ & $2.50 E+02$ & $2.60 E+02$ & $2.51 \mathrm{E}+02$ & $2.56 \mathrm{E}+02$ & $2.53 E+02$ \\
\hline 2010 & 26,812 & 104.0 & $2.54 \mathrm{E}+02$ & $2.48 E+02$ & $2.60 E+02$ & $2.55 \mathrm{E}+02$ & $2.60 E+02$ & $2.58 E+02$ \\
\hline 2011 & 26,221 & 104.0 & $2.53 E+02$ & $2.46 \mathrm{E}+02$ & $2.60 E+02$ & $2.50 \mathrm{E}+02$ & $2.55 E+02$ & $2.52 E+02$ \\
\hline 2012 & 25,592 & 104.3 & $2.52 E+02$ & $2.44 \mathrm{E}+02$ & $2.60 E+02$ & $2.43 \mathrm{E}+02$ & $2.48 \mathrm{E}+02$ & $2.45 E+02$ \\
\hline Total & 386,700 & $1,551.5$ & & & & & & \\
\hline
\end{tabular}

Table 20. Plot data for standby MDP run $\leq 1$-hour run-hours trend. Figure 10

\begin{tabular}{|c|c|c|c|c|c|c|c|c|}
\hline \multirow[b]{2}{*}{ FY } & \multirow[b]{2}{*}{ Hours } & \multirow[b]{2}{*}{$\begin{array}{c}\text { Reactor } \\
\text { Years }\end{array}$} & \multicolumn{3}{|c|}{ Regression Curve Data Points } & \multicolumn{3}{|c|}{ Plot Trend Error Bar Points } \\
\hline & & & Mean & $\begin{array}{c}\text { Lower } \\
(5 \%)\end{array}$ & $\begin{array}{l}\text { Upper } \\
(95 \%)\end{array}$ & $\begin{array}{l}\text { Lower } \\
(5 \%)\end{array}$ & $\begin{array}{l}\text { Upper } \\
(95 \%)\end{array}$ & Mean \\
\hline 1998 & 23,599 & 103.0 & & & & $2.27 E+02$ & $2.32 E+02$ & $2.29 E+02$ \\
\hline 1999 & 24,324 & 103.0 & & & & $2.34 \mathrm{E}+02$ & $2.39 E+02$ & $2.36 \mathrm{E}+02$ \\
\hline 2000 & 24,468 & 103.3 & & & & $2.34 \mathrm{E}+02$ & $2.39 E+02$ & $2.37 E+02$ \\
\hline 2001 & 24,174 & 103.0 & & & & $2.32 E+02$ & 2.37E+02 & $2.35 E+02$ \\
\hline 2002 & 24,503 & 103.0 & & & & $2.35 \mathrm{E}+02$ & $2.40 \mathrm{E}+02$ & $2.38 \mathrm{E}+02$ \\
\hline 2003 & 25,941 & 103.0 & $2.61 \mathrm{E}+02$ & $2.53 E+02$ & $2.69 E+02$ & $2.49 E+02$ & $2.54 E+02$ & $2.52 E+02$ \\
\hline 2004 & 27,047 & 103.3 & $2.60 \mathrm{E}+02$ & $2.53 E+02$ & $2.67 E+02$ & $2.59 \mathrm{E}+02$ & $2.65 E+02$ & $2.62 E+02$ \\
\hline 2005 & 27,101 & 103.0 & $2.59 \mathrm{E}+02$ & $2.53 \mathrm{E}+02$ & $2.65 E+02$ & $2.60 \mathrm{E}+02$ & $2.66 \mathrm{E}+02$ & $2.63 E+02$ \\
\hline 2006 & 26,334 & 103.0 & $2.58 \mathrm{E}+02$ & $2.53 \mathrm{E}+02$ & $2.63 E+02$ & $2.53 E+02$ & $2.58 E+02$ & $2.56 \mathrm{E}+02$ \\
\hline 2007 & 27,476 & 103.4 & $2.57 E+02$ & $2.52 E+02$ & $2.61 \mathrm{E}+02$ & $2.63 E+02$ & $2.68 E+02$ & $2.66 \mathrm{E}+02$ \\
\hline 2008 & 26,779 & 104.3 & $2.56 \mathrm{E}+02$ & $2.51 \mathrm{E}+02$ & $2.60 E+02$ & $2.54 \mathrm{E}+02$ & $2.59 \mathrm{E}+02$ & $2.57 E+02$ \\
\hline 2009 & 26,329 & 104.0 & $2.55 E+02$ & $2.50 \mathrm{E}+02$ & $2.60 E+02$ & $2.51 E+02$ & $2.56 E+02$ & $2.53 E+02$ \\
\hline 2010 & 26,812 & 104.0 & $2.54 \mathrm{E}+02$ & $2.48 \mathrm{E}+02$ & $2.60 E+02$ & $2.55 \mathrm{E}+02$ & $2.60 E+02$ & $2.58 \mathrm{E}+02$ \\
\hline 2011 & 26,221 & 104.0 & $2.53 \mathrm{E}+02$ & $2.46 \mathrm{E}+02$ & $2.60 E+02$ & $2.50 \mathrm{E}+02$ & $2.55 E+02$ & $2.52 E+02$ \\
\hline 2012 & 25,592 & 104.3 & $2.52 E+02$ & $2.44 \mathrm{E}+02$ & $2.60 E+02$ & $2.43 E+02$ & $2.48 \mathrm{E}+02$ & $2.45 E+02$ \\
\hline Total & 386,700 & $1,551.5$ & & & & & & \\
\hline
\end{tabular}


Table 21. Plot data for standby MDP run-hours trend. Figure 11

\begin{tabular}{|c|c|c|c|c|c|c|c|c|}
\hline \multirow[b]{2}{*}{ FY } & \multirow[b]{2}{*}{$\begin{array}{l}\text { Run } \\
\text { Hours }\end{array}$} & \multirow[b]{2}{*}{$\begin{array}{c}\text { Reactor } \\
\text { Years }\end{array}$} & \multicolumn{3}{|c|}{ Regression Curve Data Points } & \multicolumn{3}{|c|}{ Plot Trend Error Bar Points } \\
\hline & & & Mean & $\begin{array}{l}\text { Lower } \\
(5 \%)\end{array}$ & $\begin{array}{l}\text { Upper } \\
(95 \%)\end{array}$ & $\begin{array}{l}\text { Lower } \\
(5 \%)\end{array}$ & $\begin{array}{l}\text { Upper } \\
(95 \%)\end{array}$ & Mean \\
\hline 1998 & 933,236 & 103.0 & & & & $9.05 E+03$ & $9.08 \mathrm{E}+03$ & $9.06 \mathrm{E}+03$ \\
\hline 1999 & 916,423 & 103.0 & & & & $8.88 E+03$ & $8.91 E+03$ & $8.90 E+03$ \\
\hline 2000 & 874,515 & 103.3 & & & & $8.45 E+03$ & $8.48 E+03$ & $8.47 E+03$ \\
\hline 2001 & 885,303 & 103.0 & & & & $8.58 \mathrm{E}+03$ & $8.61 \mathrm{E}+03$ & $8.60 \mathrm{E}+03$ \\
\hline 2002 & 950,069 & 103.0 & & & & $9.21 \mathrm{E}+03$ & $9.24 \mathrm{E}+03$ & $9.22 \mathrm{E}+03$ \\
\hline 2003 & $1,066,971$ & 103.0 & $1.08 \mathrm{E}+04$ & $1.05 E+04$ & $1.11 \mathrm{E}+04$ & $1.03 E+04$ & $1.04 E+04$ & $1.04 E+04$ \\
\hline 2004 & $1,142,885$ & 103.3 & $1.09 E+04$ & $1.06 \mathrm{E}+04$ & $1.12 \mathrm{E}+04$ & $1.11 \mathrm{E}+04$ & $1.11 \mathrm{E}+04$ & $1.11 \mathrm{E}+04$ \\
\hline 2005 & $1,148,158$ & 103.0 & $1.10 \mathrm{E}+04$ & 1.07E+04 & $1.12 E+04$ & $1.11 E+04$ & $1.12 E+04$ & $1.11 E+04$ \\
\hline 2006 & $1,147,175$ & 103.0 & 1.10E+04 & $1.08 \mathrm{E}+04$ & $1.12 E+04$ & $1.11 \mathrm{E}+04$ & $1.12 E+04$ & $1.11 \mathrm{E}+04$ \\
\hline 2007 & $1,161,848$ & 103.4 & $1.11 E+04$ & $1.09 E+04$ & 1.13E+04 & $1.12 E+04$ & $1.13 E+04$ & $1.12 E+04$ \\
\hline 2008 & $1,181,872$ & 104.3 & $1.12 E+04$ & $1.10 \mathrm{E}+04$ & $1.14 \mathrm{E}+04$ & $1.13 E+04$ & $1.14 \mathrm{E}+04$ & $1.13 E+04$ \\
\hline 2009 & $1,162,200$ & 104.0 & $1.13 E+04$ & $1.11 \mathrm{E}+04$ & $1.15 E+04$ & $1.12 \mathrm{E}+04$ & $1.12 \mathrm{E}+04$ & $1.12 \mathrm{E}+04$ \\
\hline 2010 & $1,179,233$ & 104.0 & $1.13 E+04$ & $1.11 \mathrm{E}+04$ & $1.16 \mathrm{E}+04$ & $1.13 E+04$ & $1.14 \mathrm{E}+04$ & $1.13 E+04$ \\
\hline 2011 & $1,177,932$ & 104.0 & 1.14E+04 & $1.12 \mathrm{E}+04$ & 1.17E+04 & $1.13 E+04$ & $1.13 E+04$ & $1.13 E+04$ \\
\hline 2012 & $1,190,070$ & 104.3 & $1.15 E+04$ & $1.12 E+04$ & $1.18 E+04$ & $1.14 \mathrm{E}+04$ & $1.14 \mathrm{E}+04$ & $1.14 \mathrm{E}+04$ \\
\hline Total & $16,117,892$ & $1,551.5$ & & & & & & \\
\hline
\end{tabular}

Table 22. Plot data for standby MDP FTS events trend. Figure 12

\begin{tabular}{ccccccccc}
\hline & & & \multicolumn{2}{c}{ Regression Curve Data Points } & \multicolumn{2}{c}{ Plot Trend Error Bar Points } \\
\cline { 6 - 9 } FY & Failures & $\begin{array}{c}\text { Reactor } \\
\text { Years }\end{array}$ & Mean & $\begin{array}{c}\text { Lower } \\
\mathbf{( 5 \% )}\end{array}$ & $\begin{array}{c}\text { Upper } \\
\mathbf{( 9 5 \% )}\end{array}$ & $\begin{array}{c}\text { Lower } \\
\mathbf{( 5 \% )}\end{array}$ & $\begin{array}{c}\text { Upper } \\
\mathbf{( 9 5 \% )}\end{array}$ & Mean \\
\hline 1998 & 31 & 103.0 & & & & $2.17 \mathrm{E}-01$ & $4.02 \mathrm{E}-01$ & $2.98 \mathrm{E}-01$ \\
\hline 1999 & 24 & 103.0 & & & & $1.61 \mathrm{E}-01$ & $3.25 \mathrm{E}-01$ & $2.32 \mathrm{E}-01$ \\
\hline 2000 & 27 & 103.3 & & & & $1.84 \mathrm{E}-01$ & $3.57 \mathrm{E}-01$ & $2.60 \mathrm{E}-01$ \\
\hline 2001 & 29 & 103.0 & & & & $2.01 \mathrm{E}-01$ & $3.80 \mathrm{E}-01$ & $2.79 \mathrm{E}-01$ \\
\hline 2002 & 18 & 103.0 & & & & $1.14 \mathrm{E}-01$ & $2.59 \mathrm{E}-01$ & $1.75 \mathrm{E}-01$ \\
\hline 2003 & 39 & 103.0 & $2.98 \mathrm{E}-01$ & $2.31 \mathrm{E}-01$ & $3.83 \mathrm{E}-01$ & $2.82 \mathrm{E}-01$ & $4.88 \mathrm{E}-01$ & $3.74 \mathrm{E}-01$ \\
\hline 2004 & 25 & 103.3 & $2.68 \mathrm{E}-01$ & $2.17 \mathrm{E}-01$ & $3.30 \mathrm{E}-01$ & $1.68 \mathrm{E}-01$ & $3.35 \mathrm{E}-01$ & $2.41 \mathrm{E}-01$ \\
\hline 2005 & 19 & 103.0 & $2.41 \mathrm{E}-01$ & $2.01 \mathrm{E}-01$ & $2.87 \mathrm{E}-01$ & $1.22 \mathrm{E}-01$ & $2.70 \mathrm{E}-01$ & $1.85 \mathrm{E}-01$ \\
\hline 2006 & 22 & 103.0 & $2.16 \mathrm{E}-01$ & $1.85 \mathrm{E}-01$ & $2.53 \mathrm{E}-01$ & $1.45 \mathrm{E}-01$ & $3.03 \mathrm{E}-01$ & $2.13 \mathrm{E}-01$ \\
\hline 2007 & 24 & 103.4 & $1.95 \mathrm{E}-01$ & $1.67 \mathrm{E}-01$ & $2.27 \mathrm{E}-01$ & $1.60 \mathrm{E}-01$ & $3.24 \mathrm{E}-01$ & $2.31 \mathrm{E}-01$ \\
\hline 2008 & 16 & 104.3 & $1.75 \mathrm{E}-01$ & $1.48 \mathrm{E}-01$ & $2.07 \mathrm{E}-01$ & $9.77 \mathrm{E}-02$ & $2.33 \mathrm{E}-01$ & $1.54 \mathrm{E}-01$ \\
\hline 2009 & 17 & 104.0 & $1.57 \mathrm{E}-01$ & $1.29 \mathrm{E}-01$ & $1.92 \mathrm{E}-01$ & $1.05 \mathrm{E}-01$ & $2.45 \mathrm{E}-01$ & $1.64 \mathrm{E}-01$ \\
\hline 2010 & 12 & 104.0 & $1.42 \mathrm{E}-01$ & $1.12 \mathrm{E}-01$ & $1.79 \mathrm{E}-01$ & $6.86 \mathrm{E}-02$ & $1.88 \mathrm{E}-01$ & $1.17 \mathrm{E}-01$ \\
\hline 2011 & 17 & 104.0 & $1.27 \mathrm{E}-01$ & $9.64 \mathrm{E}-02$ & $1.68 \mathrm{E}-01$ & $1.05 \mathrm{E}-01$ & $2.45 \mathrm{E}-01$ & $1.64 \mathrm{E}-01$ \\
\hline 2012 & 12 & 104.3 & $1.15 \mathrm{E}-01$ & $8.27 \mathrm{E}-02$ & $1.59 \mathrm{E}-01$ & $6.84 \mathrm{E}-02$ & $1.88 \mathrm{E}-01$ & $1.17 \mathrm{E}-01$ \\
\hline Total & 332 & $1,551.5$ & & & & & & \\
\hline
\end{tabular}


Table 23. Plot data for standby MDP FTR $\leq 1 \mathrm{H}$ events trend. Figure 13

\begin{tabular}{|c|c|c|c|c|c|c|c|c|}
\hline \multirow[b]{2}{*}{ FY } & \multirow[b]{2}{*}{$\begin{array}{c}\text { Failure } \\
\mathbf{s}\end{array}$} & \multirow[b]{2}{*}{$\begin{array}{c}\text { Reactor } \\
\text { Years }\end{array}$} & \multicolumn{3}{|c|}{ Regression Curve Data Points } & \multicolumn{3}{|c|}{ Plot Trend Error Bar Points } \\
\hline & & & Mean & $\begin{array}{c}\text { Lower } \\
(5 \%)\end{array}$ & $\begin{array}{l}\text { Upper } \\
(95 \%) \\
\end{array}$ & $\begin{array}{c}\text { Lower } \\
(5 \%)\end{array}$ & $\begin{array}{l}\text { Upper } \\
(95 \%)\end{array}$ & Mean \\
\hline 1998 & 6 & 103.0 & & & & $2.46 \mathrm{E}-02$ & $1.04 \mathrm{E}-01$ & $5.42 \mathrm{E}-02$ \\
\hline 1999 & 3 & 103.0 & & & & $9.03 E-03$ & $7.05 \mathrm{E}-02$ & $2.92 \mathrm{E}-02$ \\
\hline 2000 & 4 & 103.3 & & & & $1.38 \mathrm{E}-02$ & $8.18 \mathrm{E}-02$ & $3.74 \mathrm{E}-02$ \\
\hline 2001 & 1 & 103.0 & & & & $1.47 \mathrm{E}-03$ & $4.61 \mathrm{E}-02$ & $1.25 \mathrm{E}-02$ \\
\hline 2002 & 6 & 103.0 & & & & $2.46 \mathrm{E}-02$ & $1.04 \mathrm{E}-01$ & $5.42 \mathrm{E}-02$ \\
\hline 2003 & 2 & 103.0 & $2.98 \mathrm{E}-02$ & $2.01 \mathrm{E}-02$ & $4.44 \mathrm{E}-02$ & 4.77E-03 & $5.86 \mathrm{E}-02$ & $2.08 \mathrm{E}-02$ \\
\hline 2004 & 3 & 103.3 & $2.95 \mathrm{E}-02$ & 2.10E-02 & 4.12E-02 & $9.01 \mathrm{E}-03$ & 7.03E-02 & $2.91 \mathrm{E}-02$ \\
\hline 2005 & 5 & 103.0 & $2.91 \mathrm{E}-02$ & 2.19E-02 & $3.86 \mathrm{E}-02$ & $1.91 \mathrm{E}-02$ & $9.32 \mathrm{E}-02$ & $4.58 \mathrm{E}-02$ \\
\hline 2006 & 4 & 103.0 & $2.87 \mathrm{E}-02$ & $2.25 E-02$ & $3.65 \mathrm{E}-02$ & $1.39 \mathrm{E}-02$ & $8.20 \mathrm{E}-02$ & $3.75 \mathrm{E}-02$ \\
\hline 2007 & 3 & 103.4 & $2.83 \mathrm{E}-02$ & $2.28 \mathrm{E}-02$ & $3.52 \mathrm{E}-02$ & $9.00 \mathrm{E}-03$ & $7.03 \mathrm{E}-02$ & $2.91 \mathrm{E}-02$ \\
\hline 2008 & 2 & 104.3 & $2.80 \mathrm{E}-02$ & $2.24 \mathrm{E}-02$ & $3.48 \mathrm{E}-02$ & $4.72 \mathrm{E}-03$ & $5.80 \mathrm{E}-02$ & $2.06 \mathrm{E}-02$ \\
\hline 2009 & 3 & 104.0 & $2.76 \mathrm{E}-02$ & 2.16E-02 & $3.53 \mathrm{E}-02$ & 8.96E-03 & $6.99 \mathrm{E}-02$ & $2.89 E-02$ \\
\hline 2010 & 2 & 104.0 & $2.72 \mathrm{E}-02$ & $2.04 E-02$ & $3.64 \mathrm{E}-02$ & 4.73E-03 & $5.81 \mathrm{E}-02$ & 2.07E-02 \\
\hline 2011 & 3 & 104.0 & $2.69 \mathrm{E}-02$ & $1.90 \mathrm{E}-02$ & 3.79E-02 & 8.96E-03 & $6.99 \mathrm{E}-02$ & $2.89 \mathrm{E}-02$ \\
\hline 2012 & 3 & 104.3 & $2.65 \mathrm{E}-02$ & 1.77E-02 & $3.98 \mathrm{E}-02$ & 8.94E-03 & $6.98 \mathrm{E}-02$ & $2.89 E-02$ \\
\hline Total & 50 & $1,551.5$ & & & & & & \\
\hline
\end{tabular}

Table 24. Plot data for standby MDP FTR $>1 \mathrm{H}$ events trend. Figure 14

\begin{tabular}{|c|c|c|c|c|c|c|c|c|}
\hline \multirow[b]{2}{*}{ FY } & \multirow[b]{2}{*}{$\begin{array}{r}\text { Failure } \\
s\end{array}$} & \multirow[b]{2}{*}{$\begin{array}{l}\text { Reactor } \\
\text { Years }\end{array}$} & \multicolumn{3}{|c|}{ Regression Curve Data Points } & \multicolumn{3}{|c|}{ Plot Trend Error Bar Points } \\
\hline & & & Mean & $\begin{array}{c}\text { Lower } \\
(5 \%)\end{array}$ & $\begin{array}{l}\text { Upper } \\
(95 \%)\end{array}$ & $\begin{array}{c}\text { Lower } \\
(5 \%)\end{array}$ & $\begin{array}{l}\text { Upper } \\
(95 \%)\end{array}$ & Mean \\
\hline 1998 & 8 & 103.0 & & & & $4.04 \mathrm{E}-02$ & $1.40 \mathrm{E}-01$ & $7.92 E-02$ \\
\hline 1999 & 6 & 103.0 & & & & $2.75 \mathrm{E}-02$ & 1.16E-01 & $6.06 \mathrm{E}-02$ \\
\hline 2000 & 11 & 103.3 & & & & $6.08 \mathrm{E}-02$ & $1.75 \mathrm{E}-01$ & $1.07 \mathrm{E}-01$ \\
\hline 2001 & 12 & 103.0 & & & & $6.81 \mathrm{E}-02$ & $1.87 \mathrm{E}-01$ & 1.16E-01 \\
\hline 2002 & 18 & 103.0 & & & & $1.12 \mathrm{E}-01$ & $2.54 \mathrm{E}-01$ & $1.72 \mathrm{E}-01$ \\
\hline 2003 & 16 & 103.0 & $1.20 E-01$ & $6.62 \mathrm{E}-02$ & 2.19E-01 & $9.72 \mathrm{E}-02$ & $2.32 \mathrm{E}-01$ & $1.54 \mathrm{E}-01$ \\
\hline 2004 & 14 & 103.3 & $1.18 \mathrm{E}-01$ & $7.10 \mathrm{E}-02$ & $1.95 \mathrm{E}-01$ & 8.23E-02 & $2.09 \mathrm{E}-01$ & $1.35 \mathrm{E}-01$ \\
\hline 2005 & 12 & 103.0 & 1.15E-01 & 7.53E-02 & $1.76 \mathrm{E}-01$ & $6.81 \mathrm{E}-02$ & $1.87 \mathrm{E}-01$ & 1.16E-01 \\
\hline 2006 & 4 & 103.0 & $1.13 E-01$ & 7.84E-02 & $1.62 \mathrm{E}-01$ & $1.55 \mathrm{E}-02$ & $9.17 \mathrm{E}-02$ & 4.19E-02 \\
\hline 2007 & 15 & 103.4 & 1.10E-01 & 7.92E-02 & $1.54 \mathrm{E}-01$ & 8.95E-02 & $2.20 \mathrm{E}-01$ & $1.44 \mathrm{E}-01$ \\
\hline 2008 & 17 & 104.3 & $1.08 \mathrm{E}-01$ & 7.71E-02 & $1.52 \mathrm{E}-01$ & $1.03 \mathrm{E}-01$ & $2.40 \mathrm{E}-01$ & $1.61 \mathrm{E}-01$ \\
\hline 2009 & 9 & 104.0 & $1.06 \mathrm{E}-01$ & 7.23E-02 & $1.55 \mathrm{E}-01$ & 4.67E-02 & $1.51 \mathrm{E}-01$ & 8.77E-02 \\
\hline 2010 & 10 & 104.0 & $1.04 \mathrm{E}-01$ & $6.61 \mathrm{E}-02$ & $1.62 \mathrm{E}-01$ & $5.35 \mathrm{E}-02$ & $1.62 \mathrm{E}-01$ & $9.70 \mathrm{E}-02$ \\
\hline 2011 & 13 & 104.0 & $1.01 \mathrm{E}-01$ & $5.94 \mathrm{E}-02$ & $1.73 E-01$ & 7.46E-02 & $1.96 \mathrm{E}-01$ & $1.25 E-01$ \\
\hline 2012 & 10 & 104.3 & $9.92 \mathrm{E}-02$ & $5.29 \mathrm{E}-02$ & $1.86 \mathrm{E}-01$ & $5.34 \mathrm{E}-02$ & $1.62 \mathrm{E}-01$ & 9.67E-02 \\
\hline Total & 175 & $1,551.5$ & & & & & & \\
\hline
\end{tabular}


Table 25. Plot data for normally running MDP start demands trend. Figure 15

\begin{tabular}{|c|c|c|c|c|c|c|c|c|}
\hline \multirow[b]{2}{*}{ FY } & \multirow[b]{2}{*}{$\begin{array}{c}\text { Deman } \\
\text { ds }\end{array}$} & \multirow[b]{2}{*}{$\begin{array}{c}\text { Reactor } \\
\text { Years }\end{array}$} & \multicolumn{3}{|c|}{ Regression Curve Data Points } & \multicolumn{3}{|c|}{ Plot Trend Error Bar Points } \\
\hline & & & Mean & $\begin{array}{c}\text { Lower } \\
\text { (5\%) }\end{array}$ & $\begin{array}{l}\text { Upper } \\
(95 \%) \\
\end{array}$ & $\begin{array}{c}\text { Lower } \\
(5 \%)\end{array}$ & $\begin{array}{l}\text { Upper } \\
(95 \%)\end{array}$ & Mean \\
\hline 1998 & 7,229 & 100.0 & & & & $7.09 E+01$ & $7.37 \mathrm{E}+01$ & $7.23 \mathrm{E}+01$ \\
\hline 1999 & 7,346 & 100.0 & & & & $7.21 \mathrm{E}+01$ & $7.49 \mathrm{E}+01$ & $7.35 \mathrm{E}+01$ \\
\hline 2000 & 7,450 & 100.3 & & & & $7.29 E+01$ & $7.57 E+01$ & $7.43 E+01$ \\
\hline 2001 & 7,415 & 100.0 & & & & $7.27 E+01$ & $7.56 \mathrm{E}+01$ & $7.42 E+01$ \\
\hline 2002 & 7,676 & 100.0 & & & & $7.53 E+01$ & $7.82 \mathrm{E}+01$ & $7.68 \mathrm{E}+01$ \\
\hline 2003 & 8,270 & 100.0 & $8.51 \mathrm{E}+01$ & $8.25 E+01$ & $8.78 E+01$ & $8.12 E+01$ & $8.42 E+01$ & 8.27E+01 \\
\hline 2004 & 8,438 & 100.3 & $8.50 \mathrm{E}+01$ & $8.28 \mathrm{E}+01$ & $8.73 E+01$ & $8.27 E+01$ & $8.57 \mathrm{E}+01$ & $8.42 E+01$ \\
\hline 2005 & 8,508 & 100.0 & $8.50 \mathrm{E}+01$ & $8.31 \mathrm{E}+01$ & $8.69 E+01$ & $8.36 \mathrm{E}+01$ & $8.66 \mathrm{E}+01$ & $8.51 E+01$ \\
\hline 2006 & 8,588 & 100.0 & $8.50 E+01$ & $8.34 \mathrm{E}+01$ & $8.66 E+01$ & $8.44 \mathrm{E}+01$ & $8.74 \mathrm{E}+01$ & $8.59 E+01$ \\
\hline 2007 & 8,745 & 100.0 & $8.49 \mathrm{E}+01$ & $8.35 \mathrm{E}+01$ & $8.64 E+01$ & $8.59 E+01$ & $8.90 E+01$ & $8.74 \mathrm{E}+01$ \\
\hline 2008 & 8,700 & 100.3 & $8.49 \mathrm{E}+01$ & $8.34 \mathrm{E}+01$ & $8.63 E+01$ & $8.52 E+01$ & $8.83 E+01$ & $8.68 \mathrm{E}+01$ \\
\hline 2009 & 8,568 & 100.0 & $8.48 \mathrm{E}+01$ & $8.32 E+01$ & $8.64 E+01$ & $8.42 E+01$ & $8.72 E+01$ & $8.57 E+01$ \\
\hline 2010 & 8,554 & 100.0 & $8.48 \mathrm{E}+01$ & $8.29 E+01$ & $8.67 E+01$ & $8.40 E+01$ & $8.71 E+01$ & $8.55 E+01$ \\
\hline 2011 & 8,348 & 100.0 & $8.47 E+01$ & $8.25 E+01$ & $8.70 E+01$ & $8.20 E+01$ & $8.50 \mathrm{E}+01$ & $8.35 E+01$ \\
\hline 2012 & 8,250 & 100.3 & $8.47 E+01$ & $8.21 \mathrm{E}+01$ & $8.74 E+01$ & $8.08 E+01$ & $8.38 E+01$ & $8.23 E+01$ \\
\hline Total & 122,085 & $1,501.1$ & & & & & & \\
\hline
\end{tabular}

Table 26. Plot data for normally running MDP run hours trend. Figure 16

\begin{tabular}{|c|c|c|c|c|c|c|c|c|}
\hline \multirow[b]{2}{*}{ FY } & \multirow[b]{2}{*}{$\begin{array}{c}\text { Run } \\
\text { Hours }\end{array}$} & \multirow[b]{2}{*}{$\begin{array}{c}\text { Reactor } \\
\text { Years }\end{array}$} & \multicolumn{3}{|c|}{ Regression Curve Data Points } & \multicolumn{3}{|c|}{ Plot Trend Error Bar Points } \\
\hline & & & Mean & $\begin{array}{c}\text { Lower } \\
(5 \%)\end{array}$ & $\begin{array}{l}\text { Upper } \\
(95 \%)\end{array}$ & $\begin{array}{c}\text { Lower } \\
(5 \%)\end{array}$ & $\begin{array}{l}\text { Upper } \\
(95 \%)\end{array}$ & Mean \\
\hline 1998 & $2,832,022$ & 100.0 & & & & $2.83 E+04$ & $2.83 E+04$ & $2.83 E+04$ \\
\hline 1999 & $2,915,625$ & 100.0 & & & & $2.91 E+04$ & $2.92 E+04$ & $2.92 \mathrm{E}+04$ \\
\hline 2000 & $2,940,279$ & 100.3 & & & & $2.93 E+04$ & $2.94 \mathrm{E}+04$ & $2.93 E+04$ \\
\hline 2001 & $2,946,540$ & 100.0 & & & & $2.94 \mathrm{E}+04$ & $2.95 E+04$ & $2.95 E+04$ \\
\hline 2002 & $2,991,227$ & 100.0 & & & & $2.99 E+04$ & $2.99 \mathrm{E}+04$ & $2.99 \mathrm{E}+04$ \\
\hline 2003 & $3,097,421$ & 100.0 & $3.13 E+04$ & $3.11 \mathrm{E}+04$ & $3.16 E+04$ & $3.10 E+04$ & $3.10 E+04$ & $3.10 E+04$ \\
\hline 2004 & $3,166,855$ & 100.3 & $3.13 E+04$ & $3.11 \mathrm{E}+04$ & $3.16 \mathrm{E}+04$ & $3.16 E+04$ & $3.16 \mathrm{E}+04$ & $3.16 \mathrm{E}+04$ \\
\hline 2005 & $3,148,465$ & 100.0 & $3.14 \mathrm{E}+04$ & $3.12 E+04$ & $3.15 E+04$ & $3.15 E+04$ & $3.15 E+04$ & $3.15 E+04$ \\
\hline 2006 & $3,137,030$ & 100.0 & $3.14 \mathrm{E}+04$ & $3.12 E+04$ & $3.15 E+04$ & $3.13 E+04$ & $3.14 E+04$ & $3.14 \mathrm{E}+04$ \\
\hline 2007 & $3,138,516$ & 100.0 & $3.14 \mathrm{E}+04$ & $3.13 E+04$ & $3.16 \mathrm{E}+04$ & $3.14 \mathrm{E}+04$ & $3.14 \mathrm{E}+04$ & $3.14 \mathrm{E}+04$ \\
\hline 2008 & $3,164,585$ & 100.3 & $3.14 E+04$ & $3.13 E+04$ & $3.16 E+04$ & $3.15 E+04$ & $3.16 E+04$ & $3.16 E+04$ \\
\hline 2009 & $3,154,559$ & 100.0 & $3.15 \mathrm{E}+04$ & $3.13 E+04$ & $3.16 E+04$ & $3.15 E+04$ & $3.16 E+04$ & $3.15 E+04$ \\
\hline 2010 & $3,152,940$ & 100.0 & $3.15 E+04$ & $3.13 E+04$ & $3.17 \mathrm{E}+04$ & $3.15 E+04$ & $3.16 \mathrm{E}+04$ & $3.15 E+04$ \\
\hline 2011 & $3,150,630$ & 100.0 & $3.15 E+04$ & $3.13 E+04$ & $3.17 E+04$ & $3.15 E+04$ & $3.15 E+04$ & $3.15 E+04$ \\
\hline 2012 & $3,150,271$ & 100.3 & $3.16 \mathrm{E}+04$ & $3.13 E+04$ & $3.18 E+04$ & $3.14 \mathrm{E}+04$ & $3.14 \mathrm{E}+04$ & $3.14 \mathrm{E}+04$ \\
\hline Total & $46,086,964$ & $1,501.1$ & & & & & & \\
\hline
\end{tabular}


Table 27. Plot data for normally running MDP FTS events trend. Figure 17

\begin{tabular}{|c|c|c|c|c|c|c|c|c|}
\hline \multirow[b]{2}{*}{ FY } & \multirow[b]{2}{*}{$\begin{array}{r}\text { Failure } \\
\mathbf{s} \\
\end{array}$} & \multirow[b]{2}{*}{$\begin{array}{l}\text { Reactor } \\
\text { Years }\end{array}$} & \multicolumn{3}{|c|}{ Regression Curve Data Points } & \multicolumn{3}{|c|}{ Plot Trend Error Bar Points } \\
\hline & & & Mean & $\begin{array}{c}\text { Lower } \\
\text { (5\%) }\end{array}$ & $\begin{array}{l}\text { Upper } \\
(95 \%)\end{array}$ & $\begin{array}{c}\text { Lower } \\
(5 \%)\end{array}$ & $\begin{array}{l}\text { Upper } \\
(95 \%)\end{array}$ & Mean \\
\hline 1998 & 11 & 100.0 & & & & $6.20 E-02$ & $1.78 \mathrm{E}-01$ & $1.09 E-01$ \\
\hline 1999 & 13 & 100.0 & & & & $7.65 E-02$ & $2.02 \mathrm{E}-01$ & $1.28 \mathrm{E}-01$ \\
\hline 2000 & 5 & 100.3 & & & & 2.16E-02 & $1.06 \mathrm{E}-01$ & $5.20 \mathrm{E}-02$ \\
\hline 2001 & 9 & 100.0 & & & & $4.79 \mathrm{E}-02$ & $1.55 \mathrm{E}-01$ & $9.00 E-02$ \\
\hline 2002 & 12 & 100.0 & & & & $6.92 \mathrm{E}-02$ & $1.90 \mathrm{E}-01$ & $1.18 \mathrm{E}-01$ \\
\hline 2003 & 14 & 100.0 & $1.11 \mathrm{E}-01$ & $8.15 E-02$ & $1.51 \mathrm{E}-01$ & 8.39E-02 & $2.13 E-01$ & 1.37E-01 \\
\hline 2004 & 10 & 100.3 & $1.05 E-01$ & 8.08E-02 & $1.36 \mathrm{E}-01$ & $5.47 \mathrm{E}-02$ & $1.66 \mathrm{E}-01$ & $9.92 E-02$ \\
\hline 2005 & 6 & 100.0 & $9.92 \mathrm{E}-02$ & $7.97 \mathrm{E}-02$ & $1.23 \mathrm{E}-01$ & $2.79 E-02$ & $1.18 \mathrm{E}-01$ & $6.16 \mathrm{E}-02$ \\
\hline 2006 & 12 & 100.0 & $9.37 \mathrm{E}-02$ & 7.76E-02 & $1.13 \mathrm{E}-01$ & $6.92 \mathrm{E}-02$ & $1.90 \mathrm{E}-01$ & $1.18 \mathrm{E}-01$ \\
\hline 2007 & 9 & 100.0 & $8.86 \mathrm{E}-02$ & $7.43 \mathrm{E}-02$ & $1.06 \mathrm{E}-01$ & $4.79 \mathrm{E}-02$ & $1.55 \mathrm{E}-01$ & $9.00 \mathrm{E}-02$ \\
\hline 2008 & 9 & 100.3 & 8.38E-02 & 6.96E-02 & $1.01 \mathrm{E}-01$ & $4.78 \mathrm{E}-02$ & $1.54 \mathrm{E}-01$ & 8.97E-02 \\
\hline 2009 & 8 & 100.0 & 7.92E-02 & $6.41 \mathrm{E}-02$ & $9.80 \mathrm{E}-02$ & $4.11 \mathrm{E}-02$ & $1.43 \mathrm{E}-01$ & 8.05E-02 \\
\hline 2010 & 8 & 100.0 & $7.49 \mathrm{E}-02$ & $5.82 \mathrm{E}-02$ & $9.64 \mathrm{E}-02$ & $4.11 \mathrm{E}-02$ & $1.43 E-01$ & $8.05 E-02$ \\
\hline 2011 & 6 & 100.0 & 7.08E-02 & $5.25 \mathrm{E}-02$ & $9.56 \mathrm{E}-02$ & $2.79 \mathrm{E}-02$ & $1.18 \mathrm{E}-01$ & $6.16 \mathrm{E}-02$ \\
\hline 2012 & 7 & 100.3 & $6.70 \mathrm{E}-02$ & $4.71 \mathrm{E}-02$ & $9.52 \mathrm{E}-02$ & $3.43 E-02$ & $1.30 \mathrm{E}-01$ & $7.08 \mathrm{E}-02$ \\
\hline Total & 139 & $1,501.1$ & & & & & & \\
\hline
\end{tabular}

Table 28. Plot data for normally running MDP FTR events trend. Figure 18

\begin{tabular}{|c|c|c|c|c|c|c|c|c|}
\hline \multirow[b]{2}{*}{ FY } & \multirow[b]{2}{*}{$\begin{array}{c}\text { Failure } \\
s\end{array}$} & \multirow[b]{2}{*}{$\begin{array}{c}\text { Reactor } \\
\text { Years }\end{array}$} & \multicolumn{3}{|c|}{ Regression Curve Data Points } & \multicolumn{3}{|c|}{ Plot Trend Error Bar Points } \\
\hline & & & Mean & $\begin{array}{c}\text { Lower } \\
\text { (5\%) }\end{array}$ & $\begin{array}{l}\text { Upper } \\
(95 \%)\end{array}$ & $\begin{array}{l}\text { Lower } \\
(5 \%)\end{array}$ & $\begin{array}{l}\text { Upper } \\
\text { (95\%) }\end{array}$ & Mean \\
\hline 1998 & 22 & 100.0 & & & & $1.46 \mathrm{E}-01$ & $3.06 \mathrm{E}-01$ & 2.15E-01 \\
\hline 1999 & 16 & 100.0 & & & & $9.98 \mathrm{E}-02$ & $2.38 \mathrm{E}-01$ & $1.58 \mathrm{E}-01$ \\
\hline 2000 & 24 & 100.3 & & & & $1.62 E-01$ & $3.28 E-01$ & 2.34E-01 \\
\hline 2001 & 16 & 100.0 & & & & $9.98 \mathrm{E}-02$ & $2.38 \mathrm{E}-01$ & $1.58 \mathrm{E}-01$ \\
\hline 2002 & 14 & 100.0 & & & & 8.47E-02 & 2.15E-01 & $1.39 \mathrm{E}-01$ \\
\hline 2003 & 10 & 100.0 & $9.31 \mathrm{E}-02$ & $5.14 \mathrm{E}-02$ & $1.69 E-01$ & $5.55 E-02$ & $1.68 \mathrm{E}-01$ & $1.00 \mathrm{E}-01$ \\
\hline 2004 & 8 & 100.3 & $9.53 \mathrm{E}-02$ & $5.74 \mathrm{E}-02$ & $1.58 \mathrm{E}-01$ & 4.14E-02 & $1.44 \mathrm{E}-01$ & $8.11 \mathrm{E}-02$ \\
\hline 2005 & 6 & 100.0 & $9.75 \mathrm{E}-02$ & $6.37 E-02$ & $1.49 \mathrm{E}-01$ & $2.82 \mathrm{E}-02$ & $1.20 \mathrm{E}-01$ & $6.22 \mathrm{E}-02$ \\
\hline 2006 & 10 & 100.0 & 9.97E-02 & $6.95 \mathrm{E}-02$ & $1.43 \mathrm{E}-01$ & $5.55 E-02$ & $1.68 \mathrm{E}-01$ & $1.00 \mathrm{E}-01$ \\
\hline 2007 & 11 & 100.0 & $1.02 \mathrm{E}-01$ & $7.40 \mathrm{E}-02$ & $1.40 \mathrm{E}-01$ & $6.26 \mathrm{E}-02$ & $1.80 \mathrm{E}-01$ & $1.10 \mathrm{E}-01$ \\
\hline 2008 & 15 & 100.3 & $1.04 \mathrm{E}-01$ & $7.62 \mathrm{E}-02$ & $1.43 \mathrm{E}-01$ & $9.20 \mathrm{E}-02$ & $2.26 \mathrm{E}-01$ & $1.48 \mathrm{E}-01$ \\
\hline 2009 & 25 & 100.0 & 1.07E-01 & 7.57E-02 & $1.50 \mathrm{E}-01$ & $1.70 \mathrm{E}-01$ & $3.40 \mathrm{E}-01$ & $2.44 \mathrm{E}-01$ \\
\hline 2010 & 8 & 100.0 & $1.09 \mathrm{E}-01$ & 7.31E-02 & $1.63 \mathrm{E}-01$ & 4.15E-02 & $1.44 \mathrm{E}-01$ & $8.13 E-02$ \\
\hline 2011 & 9 & 100.0 & $1.12 \mathrm{E}-01$ & $6.93 E-02$ & $1.80 \mathrm{E}-01$ & $4.84 \mathrm{E}-02$ & $1.56 \mathrm{E}-01$ & $9.09 \mathrm{E}-02$ \\
\hline 2012 & 9 & 100.3 & $1.14 \mathrm{E}-01$ & $6.50 \mathrm{E}-02$ & $2.01 \mathrm{E}-01$ & $4.83 E-02$ & $1.56 \mathrm{E}-01$ & $9.07 E-02$ \\
\hline Total & 203 & $1,501.1$ & & & & & & \\
\hline
\end{tabular}




\section{REFERENCES}

1. Nuclear Regulatory Commission, Component Reliability Data Sheets Update 2010, January 2012, http://nrcoe.inl.gov/resultsdb/publicdocs/AvgPerf/ComponentReliabilityDataSheets2010.pdf

2. S.A. Eide et al., Industry-Average Performance for Components and Initiating Events at U.S. Commercial Nuclear Power Plants, NUREG/CR-6928, Nuclear Regulatory Commission, February 2007.

3. C.L. Atwood, et al. Handbook of Parameter Estimation for Probabilistic Risk Assessment, NUREG/CR-6823, September 2003. 
